NYPL RESEARCH LIBRARIES

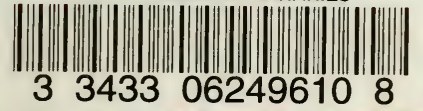




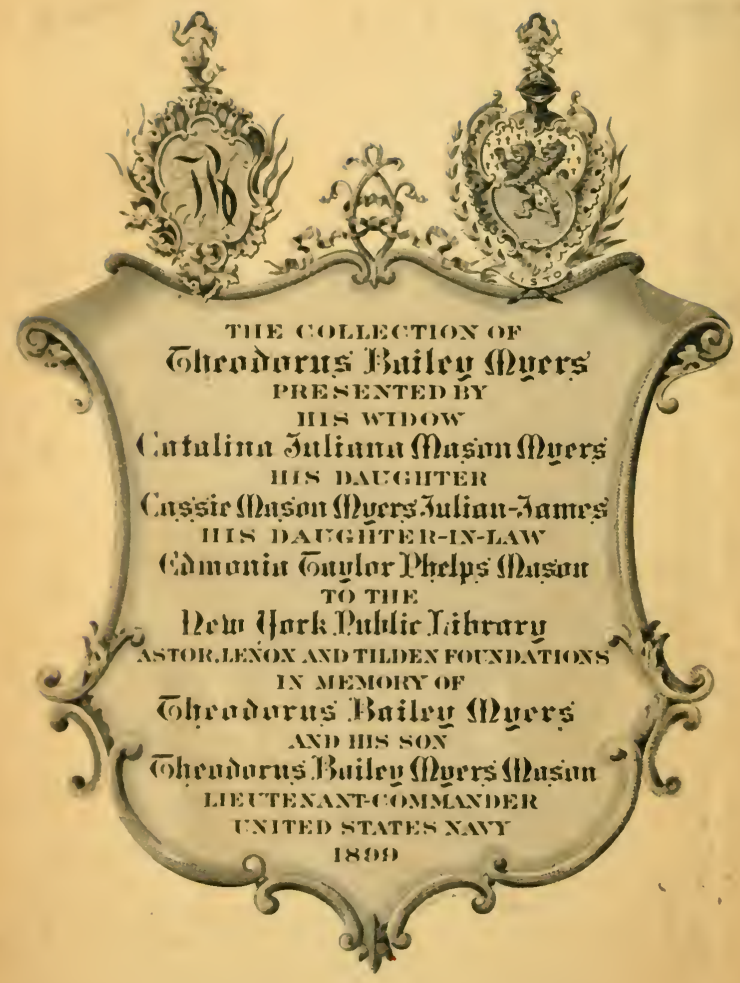


Cinton $I R$ 


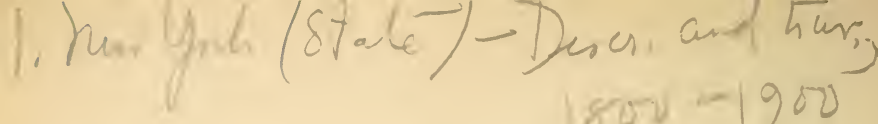

$$
\begin{aligned}
& 2^{2} C_{\text {anala }}-M \cdot S \cdot-M \cdot y \\
& 1-4 r^{-5} \\
& 2-5 \text { FI }
\end{aligned}
$$




$$
\text { - }
$$

\section{.}





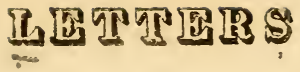

ON THE

N.ATUR.AL HISTORY

AND

INTERNAL RESOURCES

OF THE

STATE OF NEW-YORK.

\section{BY HIBERNICUS.}

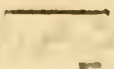

NEW-YORK:

SOLD BY E. BLISS \& E. IWHTE,

NO. 128 BROADWAY,

1822. 


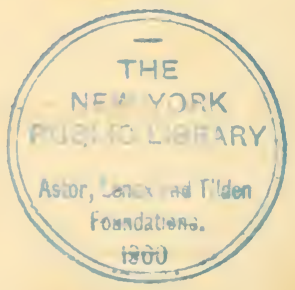

of $F$ 2. 


\section{NOTE。}

'f nowspaper during the year 1820. They attracted much attention at that time, and were copied and read with great avidity. They are evidently the production of no ordinary mind, and bence curiosity was awakened to discover the learned traveller, whose acute perception and just delineation had opened to our view some of the hidden beauties of our state. It is not for the publisher to say how far the opinion of the literary community was correct in ascribing these letters to an eminent statesman, whose researches in science night well justify such a suspicion: They are nuw collected in a volume and offered to the public, from a conviction that their merits entitle them to a form adapted to the libraries of this reading people. 
Digitized by the Internet Archive in 2008 with funding from Microsoft Corporation 


\title{
QETTERS OF HIBERNICUS.
}

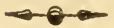 \\ TO THE EDITOE OF THE NEW-YORE STATESHAX.
}

June $9 t h, 1820$.

SiR,

I SEND you extracts of letters which I have received from a highly respectable foreigner, on the subject of the Western and Northern Canals. It appears that he is on a tour of observation-my acquaintance with him commenced last autumn, at Mrs. Mann's boarding-house in New-York, and has since grown into intimacy. His letters occasionally glance on subjects of natural science, sometimes on the peculiarity of our manners, and the state of our social and political institutions. 'They were obviously written in great haste, exhibiting no marks of lime labor, and probably were never revised, corrected, or copied by the writer. If these which I now send to you shall be favorably considered, I shall, if I have leisure furnish you with more. 


\section{LETTER I.}

Montezuma, 26th Miay, 1820.

I ARRIVE here yesterday, my dear Sir, in the bucket boat Chief Engineer, which plies between this place and Utica, as consort to the Mentezuma. The latter is a boat 74 feet long and 13 fect wide, which draws, when not loaded, seven inches of water, and when loaded eleven. These passage boats take a trip and a half twice a week between Ltica and Montezuma on the canal. 'I he distance is about 96 miles, and although the whole voyage can be performed in 24 hours, yet it generaily takes nearly two days. They are lirawn by two horses at the rate of four miles an hour, which are relicved by relays at the distance of every twdie miles. The expense of a passage from Utica to Montezuma is four dollars only, including provisions and a birth for lodging; and 1 assure you that the accommodations are as good as can be found on board of the steam boats. There is also a regular packet between Utica and Rome, which takes a trip once a day. By a trip I mean the voyage out and home. We passed ecveral boats, rafts, and scows on our passage. Some were built on the canal, and others transported to it from the Molawk and Seneca rivers- 
At Montezuma, a boat is now on the stocks, of still larger dinensions, and more accommodating arrangements than the one of that name. The whole expense of each of these boats, furniture included, will not exceed 900 or 1000 dollars. They are principally designed, and partly owned, by Colonel Tyler, of this village-a gentleman who unites kindness of behaviour and benevolence of disposition, with intelligence and enterprise. Although I am persuaded that the owners of these vehicles of conveyance will be amply remunerated for their public spirit, yet I am equally convinced that the conveyance of passengers will be principally by land, and of commodities by water, after the prevailing curiosity to visit the canal is gratified. In the mean time, there will be a competition between the carriers by land and water, for custom; and a like competition between the proprietors of stages and boats for passengers, which will add greatly, by decreasing the price of transportation, to the general benefit of the country - and by good and easy accommodations to the convenience of travellers. But as commodities can be transported with more safety, certainty, and expedition, and at less expense on the canal, and persons in the same way by land, a division of employment will fually and necessarily take place, mutually beneficial to each, and in- 
calculably advantageous to the cardinal interesta of the community. When the great six horse, heary teams are banished from use, the roads will be improved. The tippling houses, which derive their principal support from teamsters; will fall into disusc. The good inns on the road will meet with greater enconragement, because travelling will increase with population and business. The exising settlements and villages on the esrablished roads will continue to prosper, while an immense mass of propulation will appear on the banks of the canals.

I am called of by Dr. Clark, (a very worthy gen:leman, who is settled at this ploce) to visit the salt works under his direction; but you shall hear from me again rery soon.

Yours.

\section{HIBERNICL'S.}

\section{LETTEP II.}

$$
\text { Ithaca, 1st June, 1520. }
$$

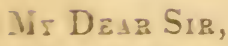

I HAvE this moment arrived in this place, by water, from Montezuma. The Great Canal enters the Seneca river by a lock; and after this you 
way eitber descend by water into Lahe Ontario by the way of Oswego, or you may proceed by the way of Three River Point to the Oneida Lake, and, pursuing the waters of Wood Creek, re-ezter the Great Canal a few miles west of Rome-thus performing, in the latter case, a voyage of circumnavigation round an immense island-or you may ascend the Junction river, formed $b y$ the Canandaigua outlet and Mud Creet, as far as Lyonsor you may proceed up the Seneca river to the Cayuga lahe as far as this place, which is distant about twenty-eight miles from the head waters of the Susquehannah-or jou may continue your course up the Seneca river through the locks and canals of the Seneca Lock Narigation Company; as far as Geneva, and from thence 40 miles to the southern extremity of the Seneca Lake. Who would have thought of such various and vast facilities of communication created by the Western Canal? From Scienectady to the south end of Cayuga or Seneca Labes, you may proceed by an uniaterrupted avigation to the exten: of near ¿50 miles- - hich will be enlarged $w$ hen the cacal reaches the Genesee river, forty wiles through the interior of the most fertile country in the world. Imagination, in this case, lags belind reality, and the utmos: stretch of poetic vision beconses embodied into esisince. I passed trom Moate 
zuma in a small boat to Cayuga bridge, where I entered a fine now steam boat called the Enterprise, of 120 tons, and 24 horse power, and arrived in a few hours through a charming country to this delightful village. The scenery of thesc lakes is alternately picturesque, beautiful, and sublime. Before the revolution of a century, this country will become consecrated to classic inspiration-"live in description, and grow green in song."

But I shall waive digressions from my main object, which was to afford you a distinct view of the Great Canal. The whole extent of this stupcindous work will be from Lake Erie to Hudson's river, a distance on an air line of perhaps 280 miles-in the route of the canal, of abont 363. This work has been distributed into three great sections-western, middle, and eastern. The middle extends from Uitica to Montezuma on the Seneca river. It was supposed that the extent of this sectiou is 94 miles, but in arranging the mile-boards it is found that it will be 96 ; and this miscalculation arose from sumning up the distances of the subordinate sections for execution, without taking into the calculation the numerous bridges, the aqueducts, locks, \&c. There is a lateral canal, from the main canal to the Salina Salt Worlis, of one mile and forty-thrce chains, 
and which cost $\$ 6,0447$. The width of the canal on the water surface is 40 feet-at the bo:tom 28, and its depth is four feet. The length of a lock is 90 feet, and its width in the clear is 14. Vessels of 100 tons may pass through this canal with ease, and will convey greater loads than any of the Hudson sloops. One level extends from seven miles east of Utica to near Syracuse, a distance of 69 miles; and on the west side of Genesee river, there is another level of 70 miles. Similar instances of extensive levels are unprecedented as applied to any given canal. There are on the middle section nine locks, and a number of occupation and road bridges, waste grates, safeiy gates, tumbling bays or weirs, culverts, aqueducts, aqueduct bridges, embankments, and deep cuttings, but not a single tunnel, drawbridge, or reservoir; and on the whole route I observed but one artiticial feeder, the canal being abundantly supplied by natural streams. This canal is constructed in the most solid and durable manner, and the water which fills it is as copious and as perennial as the lakes and springs fiom which it issues. This work was commenced at the eastcrn end of the section, and as you proceed to the west, you observe increased improvement, arising unquestionably from augmented experience and deep reflection. The loclis are built of 
lime or sand stone, and are cemented by mortar inade of a calcareous stone found in various parts of this country. I never saw better work, promising a longer uninterrupted duration. This caral was commenced on the 4th of July, 1817, and last autumn it was navigab!e. In twentynine months this gigantic operation was completed.

'The western canal, so far as finished, incluling the Salina canal, is 98 miles long, 98 In the same pcriod a canal from Lake Champlain to Hudson river has been constructed 21 miles long,

'Thus these works have been made at the rate of upwards of four miles a month, or fifty miles a year. 'That part of the western section reaching from the Sencca to the Gencsee river, a distance of 63 miles, and that portion of the eastern scction from Lica to the Little Falls, about 26 miles in length, making in the aggregate about 90 miles, will be finished next year, which is at the rate of 45 miles a year. On this part of the western section there will be 16 locks, and of the eastern at least 5 lociss. Lifer tise year 1821 , there will then remain to finisi: of the great canal, about 95 miles in the western, and 75 in the eastern secticn, 
Which can, as I understand, be easily cficcted by the first of December, 1823. Indeed, it is confidently said, that with adequate funds, 100 miles of this canal can be annually made. In the work to be finished, there are more locks in proportion to the distance, than in the middle section;-while the latter only has 9 locks, there will be 25 in the western, and 56 in the eastern section. From Lake Erie to the Seneca river is a fall of 194 feet, and from Utica to Hudson river, a fall of 418 feet. But there is no magic in erecting a lock, either as to time or slill. The great pressure of water demands strength, and the massy weight of the superstructure requires a solid foundaticn. The larger the stones the better. In the locks near Salina I saw sand stones which weighed four tons; they were moved by cranes and placed on the walls with as much ease as a man would liandle a brick; and the lock at Montezuma was constructed last year in six weeks.

The average expense of the middle section is $\$ 11,792$ per mile. 'The cost of the western is cstimated at $\$ 10,944$; and of the eastern, at $\$ 21,096$ per mile. Never has so much work been done in so short a time, at so sinall an expense.

Twenty miles west of the Genesee river, the canal will strike the navigable waters of the Touawanta creek, which discharges itself into Lake 
Erie. Before the final completion of this great work, a person may therefore take a barge at New-York, and pass by water into Lake Erie, by in uninterrupted navigation.

\section{LETTER III.}

$\because$

Geneva, 6th Jine, 1820。

Mr Dear Sir,

As I write without "reference to note or comment," it is probable that I may commit some trifling errors, and slide into repetition. I aspire to no higher honos: than that of an old chronicle, by giving you a dull, but true account, of this wonderful canal and wonderful country. I have travelled from one end of Europe to the other, and have seen much of the western world, but 1 have never before witnessed such scenes and operations, as have been recently presented to my vision.

When I went on the canal, there were no fixed days for the starting of the barges with passengers: It appears from the advertisement which I now subjoin, that they are regulated. I believe that cheaper and more commodious travelling cannot be found. For eight dollars you can go: 
in four days 200 miles, without a jolt, or the least fatigue, and employ the whole time in reading, writing, rational conversation, amnsement, or viewing the most interesting region of the globe. The notice is as follows, to wit:

"Boats for the accommodation of passengers 100 miles on the canal, are now in operation by the 'Erie Canal Navigation Company.' They sail every Monday and Thursday morning from Utica, at 9 o'clock, and arrive at Canistota, (Lenox) at $7 \mathrm{p}$. m. proceed next day at $2 \mathrm{a}$. $\mathrm{m}$. and arrive at Montezuma at $7 \mathrm{p} . \mathrm{m}$.

Returning-Sail from Montezuma on Mondays and Thursdays, at 8 o'clock a. m. arrive at Syracuse (Salina) at 7 p. m. proceed next day at $2 \mathrm{a}$ a $\mathrm{m}$. and arrive at Utica at 6 p. m. Price of passage through the route, including provision and lodging, \$4. Way passengers three cents per mile. A small advance to be made on the price of passage when the Toll and Lockage are estubished. Baggage at the owner's risk. For passage apply to Doolittle \& Gold, or at the Stage Otfice, Utica. To Richard Smith, imnkeeper, Montezuma, or to the captains on board."

Canistota is about 36 miles from Utica, and Syracuse the same distance from Montezum-. After leaving Utica, you pass through a fine, fertile, well cultivated country to Rome. The villages of Whitesborough and Oriskany intervenethe former is a most elegant place; the latter is the seat of great hydraulic establishments. It is 
curious to observe the heterogenous collection of names of places derived from the aborigines, the ancient Greeks, Romans, Jews, \&c. on the route of the canal. You begin with Utica, and proceed to Whitesborough, Oriskany, Rome, Oneida, Verona, Canistota, Macedonia, Jordan, Syracuse, Bucksville, \&c. to Montezuma. Some of these are villages which have sprung up with the canal, and others will follow with such rapidity that I have no doubt that both banks will, in the course of a few years, exhibit one uninterrupted range of compact population. Already have spacious basins for the accommodation of boats been established. At Syracuse there is a dock, warehouses, weighing maclines, crancs, and all the other appendages of a great establishment. At several jlaces I saw boats on the stocks ready for launching. Sometimes the great western turnpike approaches within view of the canal, but generally it is a few miles to the south. On this road there are numerous villages and scttlements, fine houses, churches, academies, and other public edifices, which instead of being affected by the establishunent of new ones on the canal, will derive addiional aliment and support. In proportion to the increase of population, will be the increase of consumption. This will augment the demands for subsistence and clothing-for the necessaries 
comforts, and luxuries of life. The country intervening between the two great land and water routes will be shortly settled, and the north side of the canal to the Seneca river will be equally so. On the south side of the middle section of the canal, there are two great turupike roads, running in the same direction, and the Cayuga, Owasco, Slianeateles, Otisco, Cazenovia, and Little Lalics. On the north side, the waters of the Seneca river, Oneida outlet, Oneida lake, and Wood creek, furnish a navigable communication with Lake Ontario, or the Mohawk, and a great turnpike road is now making: And there are besides, the great lake Ontario, Oneida, Onondaga, and Cross lakes. The west and the east will thus communicate by a great artificial navigation, by rivers and lakes, and by three great turnpike roads. The multiplication of these channels of connexion will hind the most distant regions together by indissoluble bonds. But the canal is pre-eminent over all the others in the vastness of its usefulness, and in the extent of its accommedation.

After leaving Rome, you pass into a great swamp, covered with timber, and formed by the recession of the waters of a vast lake, which has now dwindled down into Oucida lake. This region extends 16 miles to Oncida creek, when you pass into a cultivated country. The contrast is 
like passing from a half lighted room, into an apartment blazing with lamps.

After this, you continue your course through a country generally unsettled, until you arrive at Syracuse, opposite to Salina, and 61 miles from Utica, where Judge Forman, a gentleman of great intelligence and activity, is erecting a town. The region west to Montezuma is of the same character. When you pass Geddesburgh, the Onondaga lake stretches out its waters to the north, and as it were under your feet; a more beautiful prospect my eyes never beheld. In this region mighty deeds of valor have been performed. Here the great congress, parliament, or wittenagemote, of the Iroquois, or Six Nations assembled to deliberate on the concerns of the federal republic. Here the Jesuits established themselves, and encountered death and all its terrors to establish the dominion of the cross. But I am called off to witness a singular sight-a great bald eagle chasing an osprey over the Sene ca lake-a great fish falls from the mouth of the latter, and the imperial bird darts at the falling fish with the rapidity of lightning, and grasps it in his talons. 


\section{LETTER IV.}

Aurora, 9th June, 1820.

My Dear Sir,

Is passing from Aurora, along the eastern bank of the Cayuga Lake towards the bridge, I met with several objects of great interest, and I much regretted that my time did not admit of a visit to a distinguished naturalist of the society of Friends, David Thomas, who lives in this vicinity. Whether these interior lakes have been formed from the retreat of the ocean, and are in a state of gradual subsidence; or whether they have been produced by springs and deposits of watcr in great cavities, enlarging gradually their dimensions by breaking down the feeble barriers of schist with which they are surrounded, are still points subjudice. As I proceeded on the banks of this lake, which exhibit a grandeur and beanty of scenery, far transcending any thing of the kind I have seen in Europe, I frequently came to the seats of ancient Indian nations, selected as such for theirabundance of vegetable subsistence, fishes, birds and beasts. I was utterly astonished when I reached the Union Springs, formed by the junction of exuberant fountains springing up from the earth, and forming instantaneously a water power 
for most hydraulic purposes. At this place valuable mills have heen erected by William S. Burling, a very worthy and intelligent man, under whose auspices a pleasant village has been established.

Owasco Lake lies about 16 miles east of these springs, and is at least 150 feet higher than the Cayuga Lake-and as the intermediate country reposes on lime stone, some suppose that Union Springs are the out burst of a subterranean cominunication. A similar opinion prevails about the origin of the springs at Caledonia in Genesee. The progress of time and inquiry will ascertain the solidity of these speculations.

This is the fincst wheat country in the world.The white bald wheat with red chafi is the principal grain, and all the materials of a great hydraulic establishment, can be brought to and sent from the works by water. Gypsum lines ten miles of the eastern bank of this lake. The Cockscomb plaster, a singular variety of marl, is to be found in great plenty, and also inexhaustible stores of the latter in its common state.

The Cayuga Lake abounds with fine fish, and among others, with the white fish, or salmo clupea formis of the celebrated Dr. Mitchill, who is certainly at the lead of the American scavans. The 
salmo salar is also found here and at lcast four species of esox, or pilie.

To the south you can approach by this lake the head waters of the Susquehannah and Ohio.'To the north you can enter the great Lake Ontar:o. To the west you can visit the Sencea Lake, and its connecting canal, and by diverging to the east you can navigate the middle section of the great western canal.

Such facility of navigation in connexion with a rich scil, abounding with all the means of fertilization, and producing the best fruit and grain, with a healthy climate, and delightful scenery, furnishes inducements for settlements almost irresistib!e.

In future times, the metamorphoses of Ovid will be re-produced in this romantic region. The Fountain of Arethusa will yield its renown to the exuberent Springs of Aurors; and the license of poetic imagination will spread its fairy enchantincuts oyer the w!ols !and. 


\section{LETTEP V.}

Mr Dear Sir,

Is my voyage on the canal I met witn several loaded boats and scows, ascending as well as descending, and also rafts. The facility with which boats pass each other without interruption or delay, strikes one forcibly at the first view. This canal will make a great revolution in the internal trade of the country, and in the balance of political power.

One horse can draw as much on a canal, as 60 on a road. The expense of transportation will

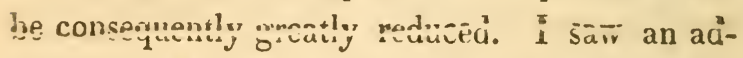
vertisement of Mr. Henry B. Ely, of Utica, wherein he offers to forward goods on the canal for 25 cents per Cwt. for 100 miles, including toll, which is about five cents a ton per mile, at least one quarter less than by land. But this I apprehend is too high; the maximum cost ought not to exceed three cents a mile per ton. I saw at Utica a raft of 440 tons of lumber, which had been floated on the canal for 20 miles, for about 50 dollars. It was drawn by four horses at the rate of two miles an hour. The conveyance of this timber by land would have cost at least $1600 \mathrm{dol}-$ lars. The price of wheat at Albany, is now about 
87 cents a bushel, and the land transportation, at any considerable distance, costs at least 44 cents. A bushel of wheat can be conveyed on the canal, when finished, from Seneca river to Albany for six cents.

Gypsum is found all over the west; you can now buy it at Utica for $\$ 150$ to $\$ 2$ a ton. The great country lying on the Hudson can be supplied with this mineral for four or five dollars a ton. Salt will also be sold at Albany for 2s. $6 d$. or $3 s$. a bushel.

I enclose you a marine, or canal list, cut from an Utica paper. The activity of business which this communication has already created is perfectly surprising.

From the Itica Patriot.

\section{CANAL NAVIGATION.}

May 22, 1820, arrived, boat Montezuma, with passengers, Engineer, Experiment, Western 'Trader, and a Cayuga boat, with flour.

Departed, Montezuma, passengers, and a Geneva boat with goods.

23. Arrived, Traveller, and Experiment.

Departed, boats Engineer, Newell, and Experiment.

24. Departed, boats Western Trader, and Experiment.

Arrived, Lady of the Lake, with stone, and John Van Ness Yates, with 250 barrels of flour, from Seneca Lake. 
1 25. Arrived, Experiment, passengers, Lady of the Lake, store, Anne Maria, with salt, from Salisa.

Departed, Experiment, Anuc Maria.

26. Arrived, boat Montezuma, with passengers, his excellency the Governor, and Gen. Van Rensselacr.

27. Arrived, boats Traveller, Clinton, and the Western Trader.

28. Arrived Engineer.

Departed, the Experiment, passengers, for Montezuma.

29. Departed, boat Montezuma, with passengers, commencing her regular trips.

30. Lady of the Lake, one scow, with stone.

31. Arrived, two Cayuga boats with flour.

Departed, Engineer, passengers.

June 1. Two boats from the Seneca Lake, do.

2 The Caristcta and John Van Ness Y ates, do.

Arrived, Montezuma, with passengers.

3. Arrived, one boat from Cayuga Lake, with pork.

Departed, one boat for Geneva, and the passage boat Experiment.

5. Departed, the Montezuma, for Seneca river, with passengers.

At Montezuma, I was regaled with most excellent fish of the esox genus; and at Syracuse and Rome, on my way up, I had fine salinon. I shall on a future occasion, speak of the fishes of the west: The fish marliets of the cities on the liudson will be greatly improved by the canal. Aew species will be bronght down in ice in a 
perfect state of preservation, and the epicures of the south will be treated with new and untried dishes of the highest flavor.

The west is the favorite region of the peach and the plum. And these and other kinds of fruits of the very best quality wil, we conveyed on the canal I have seen in various places, a plant of fine appearance, which I am told produces excellent fruit of the size and color of a small orange. It is, if I mistake not, the podophyllum peltatum and is commonly called mandrake, or May apple. This country also contains difierent species of wild plums of fine quality. The opening of a market for grain will prevent its conversion into ardent spirits-the curse of morals, and the bane of domestic felicity. Whiskey now sells for eightecn cents a gallon. What a temptation to inebriety ! a man may now keep constantly drunli, fort hree or four shillings a week. Nothing but a heavy excise can banish the use of this deleterious poison.

Cattle which are fattened for the market can be transported on the canal with less expense and with more celerity, (and without any diminution of flesh) than by driving.

In one word, new uses and striking advantages will daily present themselves to observation from this great operation. It is alleged that the canal 
will make a good ice road in winter, but I have no faith in this opinion. The use of it for such purpose will be but short. It will be in use for vessels about ten months in a year; and what is not a little extraordinary, it freezes later, and thaws sooner, than natural waters. The philosophy of this fact I will endeavor to develope on some future occasion, but such you may rely on it is the case. When the Onondaga Lake, which lies below the canal, was closed up with ice last spring, the latter was open and navigable. By thie continual passage of boats in winter, the canal can be prevented from freezing; and when frozen, a vessel may open its way by placing stampers for breaking ice at its head, as I have seen in the Forth and Clycle canal, where they are worlied by the steam engine that propels the barge.

\section{LETTER VI.}

Ny Dear Sir,

Befone leaving London I bought "An accoune of the Great Western Canal of New-York, with an illustrative map," which was reprinted at that great literary mart, and when I arrived here, the great outlines of the country and of the canal 
were familiar to $\mathrm{my}$ mind. Actual inspection has exceeded the most sanguine anticipation. Sometimes I think that $I$ am in the region of enchantment, and that the magical operations of eastern fiction are acted over again in this country. Two canals of 124 miles, uniting to a certain extent the great fresh water seas of the interior, with the ocean; and all this done without noise, and as it were without effort, in less than two years and a lalf, must shut the mouth of scepticism, and excite universal astonishment. (The more I examine into this subject, the more important consequences do I observe. The men who are the primum mobile of this scheme, appear to understand the genuine sources of national wealth, and tle orthodox principles of political economy. Internal tracle is the great substratum of riches. It excites all kinds of industry, sharpens the faculties, and multiplies the exertions of man; and inland navigation is the lever of Archimedes, which will set in motion this world of occupation and exertion.)

Both sides of the canal are in fence. This is necessary in order to protect the bank from cattle, and the farms from depredations. I was shewn at Whiteshorough, a fence, the materials of which were conveyed from Canasaraga last fall, on the canal. Twenty-two hundred cedar rails were transported with one horse, two men, and a boy; 
and it took in going and returning, three clays, at $\$ 3$ per day; in the aggregate, $\$ 9$; while by land it would have employed 40 wagons two days, which at $\$ 2$ per day, would have cost $\$ 160$.

I am of npinion that the salt of Salina can be sold at Albany, when the canal is finished, for 31 cents a bushel. At Salina it can be purchased for 25 cents a bushel, and the expense of conveyance will not exceed six cents. The principal cost now is the barrel, but when conveyed in bulk, this will of coursc be done away. I saw a salt boat building near Syracuse, which was intended to convey 1600 bushels in bulk.

In like manner gypsum can be got at Utica for $\$ 2$ a ton, and delivered at Albany for $\$ 1 \frac{1}{2}$ or $\$ 2$ more. This source of fertilization will be diffused through this clannel over the whole state. I have mucls to say on this subject, and I am now considering whether it will be best to prepare it by calcination or grinding before transportation, or transport the raw material. Suppose that 100,000 farmers should each save twenty dollars a year in gypsum, and ten dollars in salt, by means of the canal, here would be an annual saving of three millions of dollars, a sum more than sufficient in two years to make the whole canal. And this is a very moderate calculation. Salt is essential to the hea!th of cattle, and the consumption of this 
articie for that purpose, for the table, and for preserving fish and meats, is immense. Gypsum rises every year in public estimation, and $I$ am told that during the late war, the farmers of Saratoga and Dutchess counties would go to the gypsum beds of Madison and Onondaga countics for a supply, a distance of 150 or 200 miles. To shut out the foreign supply of gypsum and salt, would be a great saving to the public in every sense of the word: and this will be most effectua!ly accomplished.

A horse can easily draw 25 tons on a canal. This would take at least 20 teams for land trans portation. The conveyance of commodities by water will supersede the use of an animal for draught, which is the most voracious and wastcful of the graminivorous class of brutes. Two beneficial consequences will result, and in a most extensive manner. 1st. The diminished demand of horses for domestic accommodation, will enable a greater exportation to foreign markets : and $2 \mathrm{~d}$. Their place will be supplied by neat cattle, sheep, swine, and poultry, which will be increased in proportion to the augmented stores of grain and grass for their benefit. It has long been anxiously desired by good agriculturists to substitute the ox for the horse in farming, and though this has partially succeeded in the eastern states, yet the 
horse is almost exclusively used for the conveyance of coumodities a distance.

Every diminution of expense in transportation, will add so much to the profits of the farmer and manufacturer. Hence manufacturers will be en. abled to scll their fabrics at a low price, and to this canal I look for the resurrection and firm establishment of the manufacturing interest of the State.

I saw for the first time the famous acer saccharinum, or sugar maple. It grows spontaneously like all other trees of the forest, and is a most beautiful and stately tree. It is said that each tree will produce from three to five pounds of sugar. An acre will contain 30 trees, and a tree will be fit for use in 15 years, and will probably continue so for two centuries. An orchard of ten acres would produce annually two hogsheads and a half of sugar, which can be made as good in all respects as the produce of the cane or the sweet beet. I speak from ocular observation and from taste. Mon. Le Ray, a very respectable and sensible land holder in Jefierson county, shewed me at Washington-Hall, in New-York, a sample of maple sugar, which I have never seen excelled, and which was raised on his estates in that county; and I have been told by Mr. George Parish, a most accomplished and public spirited 
gentleman, from St. Lawrence county, that the inhabitants of that region not only supply themselves with maple sugar for domestic uses, but liave a surplus for market. This was reiterated to me at Utica lately, by Judge Ogden of the same county, and by Judge Church of Alleghany, gentlemen of great worth. A plantation of maple trees of ten acres, besides being highly ornamental and beneficial for pasture-besides the use of the decayed trees for fuel, and the acquisition of excellent syrup, vinegar, and molasses, and a sufficiency of sugar for family purposes, will yield a profit of $\$ 200$ annually to the proprietor; and these operations are carried on in the month of March, continue but a short time, and interfere with no other business. The forests of the north and west will supply the other parts of the state with the best of sugar and molasses through the great canals.

\section{LETTER VII.}

Goneva, June, 1820.

My Dear Sir,

Just before you arrive at Syracuse, 61 miles from Utica, you meet with the two first locks on the canal. Here are three which let you down into 
the Sainia Plain. These locks are made of lime and sand stone. Both abound with marine exuvix and organic remains. I never saw more substantial erections. The water cement made use of is derived from a mixture of sand and a meagre lime stone found all over this country, and is said to be superior to any hydraulic mortar ever used. I had at Utica an account of this discovery from a Dr. Bartow, one of the agents of the Canal Board, a gentleman, who possesses a great fund of information, which he was by no means parsimonious in imparting. I spent three hours very pleasantly with the Doctor at the great Utica Hotel. He informs me that on a chemical analysis, it is proved that the component parts are not the same with the Septarium, Lias, or Aberthlaw lime of Great Britain-that he and Mr. White, one of the Canal engineers, had originated and matured the discovery, and that it had been successfully iried in cisterns as well as locks, and found to unite stones as firmly and solidly as if they had been originally joined by the hand of nature.

The Doctor states the constituents to be as follows : to wit.

$$
\begin{aligned}
& 35 \text { parts carbonic acid, } \\
& 25 \text { lime, } \\
& 15 \text { silex, } \\
& 16 \text { alumine, }
\end{aligned}
$$




\section{2 water, \\ 1 oxide of iron.}

After the process of calcination, it is to be ground, and then mixed with an equal weight of clean sand, which will be twice as buky as the lime, and it must be mixed with clean water, and as little as possible.

I am told that a great limestone ridge runs through the whole of this country, cast and westthat north of it a ledge of gypsum commences; also a range of salines-and that on the borders of the gypsum and salt regions, there is a tier of lime stone alternating with sand stone, and full of organic remains; adjacent to which the water lime is found-and that this valuable fossil is in great abundance over a line of country of at least 100 miles extent. The most eastern salt spring as yet discovered is about 25 miles west of Utica ; at the same distance gypsum commences. This affinity between salt and gypsum exists all over the world. I find the geology of this country inost extraordinary; it is sui generis. In using the technology of Werner, I beg you to understand that I am no disciple of his school. I adopt it to explain my ideas in conformity to received and general momenclature. We are yet in the horn book of this science. The lapse of ages will accumulate facts for the formation of systems. - 
This earth is undoubtedly a wreck of a forme world; a new combination of cld materials. Fire and water have been the principal agents in accomplishing this work; and changes are constantly going on, somctimes with slow, at other times with rapid, and always with unceasing steps.

To adopt the language of Werner, this country of th:e west is entirely of secondary formation.Here are no primitive or transition rocks, un!ess a fe:w scattered ones, which have been cither brought from a distance by water, or ejected by volcanoes from the bowels of the earth-ard which may therefore be considered as exotic substances. I have as yet seen but shistic, calcarcous, and silicecus rocks, besides gypsum : with the exception of a few of granite at Montezuma, one of which is very large. The existence of these primitive substances in this comutry, is a great curiosity. These rocks may have been conveyed here from the rocky mountains, from Labrador, or the country north of Lalie Superior. But I have much to say on this subject, which I shall reserve until I see more of this country. In Europe all the threegreat formations run into each other, or are in a state of close approximation. In this region the secondary preciominates over the whole western country. This then is theliabitat of coal; here it must be found of the best quality, and most 
abundant quantity. Further west, in Ohio and Pennsylvania, it has becn discovered, and $1 \mathrm{am}$ confident that it exists in the vicinity of this canal. The reasons which induce this opinion are vari. ous and conclusive, and I shall now cuumeraic some of them.

Coal is composed of charcoal, or carbon, bitumen, some portion of earth, and generally a small quantity of metalic matter. When it exists witiout bitumen, it is termed anthracite or glauce coal. All the western coal contains bitumen, and gencrally speaking, the coal found east of the mountains is without it.

Coal is found in lilly situations, under strata of grit, which is a compound of sand and clay, or under schistus which is an inclurated clay, splitting into layers and forming either slate, or a substance called shivers, according to its fracture. Coal frequently alternates with strata of grit, stone and schistus. Its roof is gencrally composed of shale; and although in the island of Great Britain it is not intermingled with lime stone, which genewaily forms the outlines of coal ficlds, yet on the continent they are often found in company.

Discarding the theories which have been stated respecting the origin of coal, whether of mineral or vegetable derivation, it is sufficient mercly to state facts in order to sustain the opinion which I have ar!vanced on this subject. 
Coal is classed by geologists among the secon lary rocks or substances, and is found in regions of sccondary formation arranged in horizontal strata. The whole western country is of this character.

Again.-Its accompaniments, shale and sand stone are the principal rocks, besides lime and sypsum.

Black shale which burns in the fire, and which derives its color from the bitumen with which it is impregnated, is to be seen in various places.

Bituminous springs and oil stones exist in this rountry.

Hydrogen gas, or burning springs, are also found in this region, issuing from strata of sclist, and are of the same nature, in several respects, with the gas obtained from the distillation of coal. Sir Humplrey Davy ascribes the quantity of gas thus spontaneonsly extricated, to the consolidation of this coal, effected under a great pressure; and even when this substance owes its origin in some measure to other causes, it is in a degree always identifed with coal. For the inflammable gas of marshes consists of hydrogen and charcoal.Whenever I see this gas in a state of ignition, or issuing from the earth in its usual state, I set dowr. its origin in some measure to coal. 
Again. - The prevalence of sulphur and salt in the shape of springs, and of gypsum in the form of quarries; demonstrate the cxistence of coal. They are invariably companions. Providence dispenses its bounties in a remarkable manuer. These invaluable fossils, coal, salt and gypsum, are always found in the same region. The great ranges of hills in Canasaraga, Onondaga, Ontario, and Genessee, are ramifications of the Alleghany mountains, the seat of coal in Pittsburgh.

One of the richest salt nines in England, was discovered by digging a canal. The western canal in its windings round hills, in the deep cuttings $:$ hich it produces, and the extensive explorings and examinations which it occasions, will undoubtedly bring to light great mines of coal, more valuable than the precious metals of Peru, and the precious stones of Golconda. The places to look for this important mineral, are deep ravines, formed by floods; the vallies at the foot of high lills, and vertical sections produced by the overflowings and abrasures of streans.

Thin lamina of coal have been seen in various places-and the Indians say that they have found fire-stone in the woods. The moment coal is discovered within fifty miles of the canal, what sources of wealth will immediately be developed. Deprive Great Britain of its coal. and you ruin 
the linglom. Give it to the proud republic of New-York, and sle will soar on eagle wings above ail competition.

I write from recollection, for I travel without books-ny general statements are correct, altho: I may err in some details.

\section{LETTER VIII.}

\section{Geneva, June, 18:0.}

Mr Dear Sir,

I LIKE the air and scenery of this place so much, that I cannot leave it without regret. Thespacious hotel is replete with accommodations. The viilage hangs over the pellucid lake, which stretches litic a mighty river towards the south, and the eye is lost in tracing its exient. The aquatic birds which frequent this lake are objects of considerable interest to me, and the fishes which inhabit its waters are equally so. I have however to grope my way in the dark without any assistance. Natural science has no hold of the affections of this community. Its very terms are unknown to most members of the learned professions. Here and there some illustrious exception may be seen, but then an attack is immediately made by the witlings, the postastcrs and the sciolists of the country, 
who unite to sun down merit which they cannot imitate. Dr. Nitchill's honours of this kind are as uumerous as the documents of his scientific merit, and Dr. Hosack has been assailed by the low bufioonery of literary punchinellos and shallow-pated coxcombs. When in company with the savans of my uative country, the fame of Rush, Mitchill, Hosack, Bigelow, Belknap, Barton, Wistar and Walsh, were familiar to me-but 1 never heard of the names of Verplanck and Paulding, of Searson, of Duer, of Minshull, or of $\mathrm{Di}$. Henry, until I landed on the American shores.

The common names of European birds are applied without discrimination to American ones, and this has created endless confusion. It is rain that I look for our quail, our patridge, our woodcock, our pigeon, our swallow, our robin, our goldfinch, \&c. There is nothing of the kind to we seen. I am pointed to birds of those names, but here the resemblance ceases. The English snipe is the same in Europe and America, and probably many aquatic birds, but that snipe is the only one in which I have ascertained a complete sameness.

When on the caral in the night I was serenaded by some unknown nocturnal bird. It had fous distinct notes-its song was protracted and as welodious and sweet as the nightingale; but it 
was not the same bird. The next mormugr tue whole feathered tribe sung in delightful concert: and saluted the orient monarch of day wich mose charming music than ever $I$ heard in European forests: And this was continued after we liad entered a gloomy. swamp. A remarkable bird was visible in the wood, eclipsing all its lind by the splendour and beauty of its plumage. It was entirely of a deep red color, with the exception of black on its wings. It was the Tanagra Rubra, or Red Tanager, the most beautiful bird in Amezica. It appears inclined to solitude, and its two notes, chip churr, constantly repeated do not coryespond with its maguificent attire. I had previously seen the Loxia Cardinalis with its crested head and scarlet plumage, but it is not to be commared with the Red Tanager. There is a bird called the Orilus Phæniclus, or Red winged black hird, which is the exact reverse of the Tanager in dress and appearance, and I also sav a beautiful bird of small size with black plumage, and white on its wings, called the Bob Lincoln. I am persuaded that there are many birds, particularly small ones, which are non-descripts. I was told of a bird which is heard in the night time in the month of March, and which has never been seen. It is called the Stake Driver from the noise it makes, and is continually flying from tree to tree. It is 
ancoubtedly a nocturnal bird of the Picus tribe. I was told by an old countryman of mine; who lives in a district called the Royal Grant, that he had heard the nightingale, but this I am persuaded was a mistake. It was, he said, a night bird very small, and never distinctly visible. Dr. Mitchil! told me he observed notes which he took to be the nightingale's one night at Wood Creek, but this I believe was the same song which I heard on the canal.

There are four species of swallows here, the same number as in Great Britain, and I believe they go by the same names, although specifically. listinct.

Hirundo Rustica House Swallow.

Hirundo Pelasgia Chimney Swallow.

Hirundo Purpurea Marín.

Hirundo Riparia Bank Swallow.

The Chimney Swallow is different from its congeners; it has no furcated tail. It is a wild bird, and nestles in chimnies and hollow ${ }$ trees. I hear it descend the chimney of the room in which I sleep every night; its operations are incessant, and its chattering never ending. I have reason to think that there are more species of swallows in this country, than those enumerated. The Caprimulgus Virginianus or Whip Poor-will, is a very singular bird. It is unknown 
to Europe; its wide mouth slews that it derives its food from insects, and its cry in the nightit, although the call of love, tends to inspire melanclioly.

\section{LETTER IX.}

Sulpliur Springs, near Geneva, June, 1520. Mrdear Sir,

I Anmed here a few days ago. On my approach, my olfactory nerves were greeted by a sulphurous smell, like the fabulous exhalations of the Stygian Lake. The accommodations are bad, the country delightful, the springs curious, though not uncommon. A spring rises from the earth and immediately forms a small stream. In its ascent it passes through sulphur, and receives a strong impregnation. The water being saturated with this substance, deposits a concrete sediment. Whether it can be turned to a useful account, I cannot decide. 1 have inuch to say on these phenomena.

Besides the usual loss of water by soakage, leakage, and wastage, on the canal,'a considerable quantity will be spent in evaporation. In some countries the evaporation exceeds the rain. In others it falls short, particularly in Great Bri- 
tain. The lurmer I am inclined to believe to be the case in this state, but of this I am not certain. 'The waters of these western streams have a selfpuddling power. They are saturated with lime, gypsum, and regetable and mineral decompositious, and their depositions will gradually fill up the leaks and fissures in the canal. You know that a canal has been cut through the bog of Allan in Ireland at an inmense expense, and which is perfectly water tight. The comparative facility of maling the western canal in the worst places is obvious. The fieshets of spring and autumnthe heavy rains and snows of winter-and the operations of frost, have exhausted, the last season, all their powers against this communication, and it has stood the shock at a trifling expense. In some places there is quick sand, which ever shifting and sliding, requires strong protection against its ravages.

I presume you know that moles and rats are so injurious to canals in England, that rat caichers are employed to extirpate them. I have seen already in some places the holes of these animals: I do not know whether the brown, gray, or Norway rat, the mus decumanus of Linneus and mus sylvestris of Pennant, or the black rat, mus rattus of Linnons, have extended their migrations as far as this part of the country. They both follow 
settlements, and are grear (ravellers, and I presume that they have already established themselves in this region. Both are supposed to have been broughi to England originally from India or Persia. The Nurway rat, notwithstanding its name, is qquite runkrown in Scandinavia. He made his appearance in the Five lslands in 1768, arriving upon the wreck of a Norway ship, and according to Pennant was first seen in England about the year 1728. He has made a national conquest of the black rat, and wherever he has taken his residence, has quite extirpated it. According to Pcnnant, the black rat was indigenous in England, while Shaw supposes that he was derived from Asia. Pennant says that both rats and mice were unknown to the new world before it ivas discovered by the Europeans, and the first rats it ever knew were introduced there by a ship from Antwerp. Shaw says that the black rat was imported into South America in 1554, and is supposed to be a native of North America. I have seen in the city of New-York both the Norway and the black rat, and wherever they go they will do mischief. Taking up their habitation in houses adjacent to the canals, they will perforate the banks for drink and food.

The mus amphibius, or water rat which burrows in banks about ponds and ditches, is a still? 
more dangerous enemy. It inhabits Lurope, northern Asia, and North America, according to Linnæus. I have seen it in remote parts of the country, and it is a deadly foe to canals and mill ponds. So far as I can judge from a hasty glimpse in the boat, I have also seen the mus busarius which was some time ago discovered in the interior of Canada, and which from the magnitude of the claws of its fore feet, is formed for burrowing in the ground. It is thus described in the fifti volume of the Transactions of the Linnæen Sociey-"Mus cinercus, cauda tereti brevi subnuda, geniis saccatis, unguibus palmarum maximis tossoriis."

But a fresh water lobster, a species of cray fisli which I have not yet seen, is said to be peculiarly langerous to mill dams by its perforations : lt inhabits the Genesee river in great abundance, and is seen in many other streams. If it establishes itself in the canal, it will do great injury.

The most formidable foe still remains to be noticed. 'The mus zibcthicus, muskrat or musquash: I have already seen his holes on the banks of the canal. He is next to the bcaver, the greatest architect of the brute kind. He builds his house on bogs, in summer, of reeds, and abandons it in winter, when he lodges in holes. He also makes a bole in the side of a pond, or brook, 
leading immediately into the water, from whence it rises gradually to a dry place, where he lies in security. In winter, when the water is frozen, muskrats go under the ice and prey on the fisls. They are very destructive to trout, which is alrea$\mathrm{dy}$ in the canal. 'This animal is so useful to the furricrs, that a law has been enacted against killing it, between the first of May and the first of November, except in canals and mill ponds. I am sure that its ravages on the canals, unless restrained by severe vigilance, will greatly exceed all its benefits in making hats.

\section{LETTER X.}

Canandaigua, June, 1820.

Mr DE.IR Sir,

"OF all minerals, said Bacon, there is none like the fisheries." And I assure you that these precious commodities abound in the western waters.

The ticamans, or white fish are taken in great numbers about the falls of St. Mary's at the foot of Lalie Superior, particularly in the autumn. when that fish leaves the lakes and comes to the rumning and shallow waters to spawn. It weighs from four to sixteen pounds. So says Mackenzie the Scotch traveller ; and Mr. Rathbone, a very 
inieligent gentleman of New-York, has assured ine, that at certain seasons the Indians collect in vast multitudes at these falls to catch fish. Besides the white fish, there are the salmon trout, and several kinds of sturgeon and pike, and fiesh water herring, and a number of other kinds. Whether these fishes were originally marine animals, I cannot say. Fresh water fish will sometimes live in salt water, and vice versa. The lake of Lentini in Italy, is stocked with a sea fish called the cefalo, a species of mullet caught in the Nediterranean, and thrown into the fresh water of the lake, where they not cnly live, but increase greatly in size, and improve in flavor, and are a considerable article of luxury in the island. The lake has no communication with the sea, and is chiefly filled with rain water. Many fish run up from the ocean into fresh waters to spawn, and perhaps some fresh water fish go to the ocean for the same purpose. The fishes of the lakes can however have the benefit of the salt water it they sce fit, as those waters abound with salt springs. Ives informs us that at certain places in the Red Seat, divers go down several fathoms, and bring "p fresh water, which is found in holes or little natural wells. In this case the fresh water fish inay live in the ocean. I have no loubt but that fishes can generally accommodate themselves to 
the fluid in which they swim, whether saline or iresh.

I find all the country supplied with a hard dried codfrom New-England, which must drain it of considerable money. 1 am somewhat surpriscd at this, as it is so replete with fine fishes of its own. West of Lalse Eric, the waters coutain the common salmon, in great numbers. The last year the fisheries in Sacket's Harbor and Chaumont's Bay produced the following :

Siscoes or lake herring, 4,000 barrels, at $\$ 7$ per barrel, $\$ 28,000$

White fish, 1200 barrels, at 9 dollars, 10,800 Salmon trout, 400 do. at 14 do. 5,600

$\$ 44,400$

The distance comprised is less than twenty miles, and the quantity is exclusive of the abundance distributed fresh in the country contiguous to the fishing grounds.

Judge Bates, one of the canal enginecrs, toid me that 1000 barrcls of eels are caught at the Oswego falls, and 500 of other fish, at $\$ 10$ ner barrel,

$\$ 15,000$

As much at other places on that river, 15,000

$\$ 30,000$ 
It is not too much to say, that the western fisheries, from the falls of St. Mary's to Lake Champlain, can be made to produce a million of dollars annually.

Along the canal $\mathrm{I}$ have been regaled with the salmon and pike in great perfection. The salmo fario, or common trout is visible in various places in the canal.

The science of ichthyology is pregnant with instruction and amusement. The migration of fishes, their occasional appearance and absence their habits, \&c. are subjects of interesting inquiry. The most remarkable circumstance in their natural history is their extreme longevity and rapic grouth. A salmon weighing $7 \frac{3}{4}$ lbs. was taken on the 7th of February at Warrington, (Eng.) and marked with scissors on the back fin and tail, and turned into the river, and was again taken on the 17 th of the following March, and was then found to weigh $17 \frac{1}{2} \mathrm{lbs}$. Some of the salmon, (I mean the salmo salar of Linneus) stay in the western lakes all the year. But these may perhaps be considered estrays. 'The history of this fish is involved in much obscurity, and so indeed is that oi all erratic fish. Pemant says, that every species of salmon is found in the rivers of Kamtschatka. It is observed that each shoal keep apart from others of different species, and frequently 
prefer a separate river, notwithstanding the mouths nay be almost contiguous. Every species of salmon dies in the same river or lake in which it is born, and to which it returns to spawn. In the third year, male and female consort together, and the latter deposits its spawn in a hole formed with its tail and fins in the sand. A fish of a year's grow th continues near the place, guards the spawn, and returns to the sea with the new born fry in Norember. The salmons of Kamtschatia spawn but once in their lives; those of Siberia and Europe, the rivers of which are deep, and abound with insect food, are cnabled to continue the first great command of nature, frequently during the period of their existence. The common salmon of the western waters spawn, it is said, twice a year ; also the brook tront. Linnæus coumerates between forty and fifty difierent species of the salmo. I have reason to believe that there are screral in this country. Besides the common salmon, the salmon trout, and the brook tront, there are, I think, different species of trout in rivers and lakes, which are confounded under the general name of salmon trout and common trout. I have seen two kinds of the common Irout which are considered as of the same species but which are specifically distinct. One species generaily inhabit streams, although they go into 
the shallows of lakes in the fall and conceal themselves in the grass. 'They have red spots on the body, and square tails. The other kind have yellow spots and forked tails, and never leave the lakes. I am told that Oneida Lake is fillid in July with a small substance called lake blossom, which is undoubtedly the exuvix or ova of insects. I have seen on the Lake Baikal, the greatest lake of the old world, vast quantities of the slins of the onischus trachurus, a species of insect which abounds on the rocky shores of the lake, and is the food of the salmo lenok and sig. The salmo salar and its congeners is probably attracted into these lakes by the vast quantities of insects. I have heard a great deal of the Oswego basse, or black basse ; it is said to be the most delicious fish of the west. It is of the perca genus.

\section{LET'TER XI.}

Canandaigua, June, 1820.

My Dear Sir,

LAKE Baikal, of which I wrote to you in a late letter, is a vast distance from the sea. It is 125 leagues long, and about six in breadth. A species of seal inha its it; which was originally a sea animal, but which is now naturalized to fresh 
water. Indecd I believe that the great western lakes of Amcrica, contain a large quantity of salt water in particular places, which may be sufficient for the support of marine animals. One of the old French witers in Canada says, that a seal was at onc time seen near Montreal. The harbor of New-Iork abounded with this animal in ancient times. Robin's reef was at one period their place of rendezvous, and derives its appellation from the Dutcls word for it.

The conveyance of fish from one region to another, is not a new idea. The carp was transported to England from Spain. According to Bloche, the sterlet, or accipenser ruthenus was transported from the Volga into the lake Mælar, by Frederick I. as was the loche, cobitis barbatula, out of Germany, by the same monarch. Several little lakes, called by the Americans, ponds, have been stocked with a fine species of esox, called pickerel. How easy would it be to bring the European carp into this country. The gold fish, a beautiful little carp from China, adorns the parlours of many American ladies. The most remote and sequestered pieces of water without outlets or inlets abound with finny inhabitants, How did they come there? is a natural question, upon which I have often pondered. 
1. They may have been left after the retreat of the waters of the general deluge.

2. The ova of fishes may have been ärawn into the atmosphere with exhalations, and conveyed to a great distance.

3. Dead fishes may have been accidentally dropt into those waters by birds of prey, and on the decompusition of their bodies, the contained ova may have produced fish.

4. It is well known that whirlwinds catch up water, and carry away with it at the same time, fishes, to an amazing distance. Great shoals of herrings have been found on the highest mountains of the Feroe Islands.

5. Aquatic birds convey the ova of fishes taken in as food to different places.

The vast fecundity of fishes is astonishing. Their powers of production transcend their powers of destruction. A single ovary of the large cod has been known to contain nine millions of eggs.

I expect great changes from the junction of the western and eastern waters on the subject of fish. Already have several kinds penetrated through the canal at Rome into the Mohawk river.

1. The pickerel of the western lakes has made his appearance there. 
2. A new lind of suclier, called the black suckcl.

3. The catfish of the lakes.

4. A chub, or dace, of a silver colour, and which sometimes weighs 4 lbs. Great destruction has been made of this fish by the improper use of coculus indicus in catching it. I accidentally met a German from Schoharie county, who was bound to the Oneida Lake for catfish to stock his pond.

The canal will bring the western fishes into the castern waters. At first, worms and insects will supply them with food; their amazing fecundity will fill the streams with eggs and young - cannibal like they will subsist on each other, and in proportion to their multiplication will be the demand for, and the supply of subsistence; but as the latser will probably exceed the former, new and abundant fisheries will be brought into operation

The more, my dear sir, I see, and the more I think, of the canal, the more thoroughly am I convinced of its astonishing blessings. Nature has poured down her benefits on this favored land -and the mighty genius of enterprise has brought them to perfection.

O fortunatos nimium, sua si bona norint.

But alas! faction is at work to undermine the boon of heaven, and the gifts of Providence. 


\section{LETTER XII.}

Canandaigua, June, 1820.

Mly dear Sir,

I HAVE met in this place with many gentlenen of high standing and distinguished talents. Perhaps no village in America can boast of a brighter constellation. Here are Gideon Granger, $\mathrm{Ay}$ ron, Holly, a most indefatigable and eminent rnember of the canal board-Nathaniel Howell, chief justice of the county-John Greig, an emigrant from Scotland-several clergyinen, physicians, barristers, farmers, merchants, \&ic. who are all distinguished as men of information and public spirit. The gentlemen whom I have mentioned by name are men of uncommon endowments and high acquirements; and you can never rise from their communion, without increasing your stock of useful information. Hospitality is the order of the day in this village. The ladies are elegant in their manners and appearance, and converse well and with great facility.

I have been in other places of a different description, where a cold and icy distance prevails, and where hospitality is arrayed in frowns. This difference of manners must arise from the influence 
of a few commanling minds; and I assure you that it sheds a lustre not only on the intercourse ot polished life, but by a natural association of idcas, brightens the scenery and heightens the beauties of the country in the view of the traveller.

This western region is peopled by emigrants from different parts of the United States and Lurope. If in the evolutions of good fortune, it should so happen, that a number of meritorious persons should settle in a particular place, carrying with them the excellencies which distinguish their native country, then a most felicitous state of society must be formed. This is the case with the population of Canandaigna-and the virtues and good qualities which flourish in this delightful village, are communicated to the whole surrounding country.

Nithough there are no privileged orders in this representative democracy, yet there are distinct classes in society, which derive their existence from a difference in education, cultivation, and refinement. In cities, towns, and villages, the leading members of the learned professions, the principal merchants and agriculturists form a distinct association-and it is sometimes amusing to perceive the efforts of the novi homines to elevate themselves into this class, which is considered the first or 
highest. Among these stern republicans, I have seen a great deal of family price, and it is certainJy a natural propensity in the common people to regard with respect the descendants of those illustrious men who have been the benefactors and the ornaments of the country. I have sometimes been amused with the adoption of an appellation which I at first misunderstood. When I heard some of the lowest orders of suciety styled men of family, what, thought I, can this mean? What a nomen generalissimum for all kinds of folks-but I was soon undeceived; by a man of family is meant, in common parlance, not a man of distinguished family, but a man having a family. In every state there are great families. In every city, town, village, and district, there are great families, and the invidious airs of self-importance which some of the inbecile members of the wouldbe-patricians take upon themsclves, is often retaliated and punished by the rising up of new claimants to superiority, who bear away the honors of a fastidious aristocracy. In the middle ranks in villages, the bar keeper is an important personage and so is the mistress of the school, who is gentrally a well educated, well-behaved young woman. They set the fashions for their associates, and give the tone to opinion. In some places the stage- 
driver is a leading beau, and the keeper of tine iurnpike gatc is a man of consequence.

In the American character, I have witnessed a singula: presentation of lofty independence and maffected civility. Travel where you will you will never be treated with inattention or rudeness. Men, women: and children, are courtcous to the passing stranger. Ask as many and what quescions you please, and you will be answered to the full extent of their information-but then they will expect reciprocity. You will be assailed by a prying curiosity which investigates your name, your business, and your destination. You will be treated with perfect equality; and it will be expected from you to listen with patience to tedious narratives and multifarions speculations.

I never saw the elements of common education more generally diffused, and better undcistood. Every onc can read, and write, and cypher-can read his bible, his catechism, and his psalm book. In the norks of the most common log house, you will sce such books as the Young Man's Best Companion, Bunyan's Pilgrim's l'rogress, Herrey's Meditations, Robinson Crusoe, and Tom Iones. 'The aspirants after higher knowledge are few in number and not very ardent in the pursuit. But I can așure you that many places are honared by the residence of truly scientific men. I 
was much pleased with several of the savans of New-York, and among others with my distinguished countryman, Dr. MrNevin, and a Quaker gentleman of the name of Griscom. In Albany there is Dr. Beck ; In Utica, Dr. Coventry, and in many other villages, men whose scientific acquirements are truly respectable.

In one word, Jonathan is a sensible man, of good morals, respectable habits, and civil manners. His wife is a good, tidy housekeeper, and makes a kind affectionate companion for life. His daughters are excellent young women, beautiful, fascinating, and well informed-but, like the scenery of their native land, a little romantic withal. His sons are smart young men, capable of great things, and fully sensible of it-infected with national vanity - know a little of many things, but not an entirety of any thing. Now and then a promising genius appears among them who immediately becomes the hopes aud the spoiled child of the family. Jonathan traces up his genealogy to John Bull, Jooks upon him with great respect, and sends his most promising children to John for a transatlantic education. These boys cune back some of them loaded with science, some with foppery, some with affectation, some complete dandies, and greater fools than when they left home. Now and then a Jeficrson, a Mitchill, a Hosack, 
a Walsh, a Fush, and a Franklin, appear ; but alas, such men are few, when compared with the ephemeral fops that infest the literary world of America. But in defiance of prejudice I must however say, that Jonathan has as much native intellect, and as good morals as John Bull, and better manuers, without any surly pretensions to superiority.

\section{IETTER XIII.}

Canandaigua, June, 1820.

MY DEAR Sir,

IT is not a little extraordinary to observe the strong propensity of this republican people for titles and for claims to high distinction of family. The foundation of their government is the equality of human rights. "All men (says their celebrated declaration of independence) are created equal," and yet we perceive a continual aspiration after the gewgaws and mummeries of aristocratical governments. The golden eagle which adorns the buttonholes of the heroes of the revolution, is a favorite addition to their exalted merits. Titles abound to superfluity. Every governor is styled Excellency whether he preside over a state ar territory. His Honor and the Honorab?e, are 
applied to deputy governors, Speakers of Senates and General Courts, Chancellors, the members of the higher Judicatories, Members of Congress and State Senators ; and now and then you observe the Worshipful members of Corporations and County Courts dropping their appropriate titles, and taking a seat among the Honorables of the land. Esquire is applied to the magistracy in. general, and to the members of the bar. Sometimes His Excellency and The Honorable are invested with this magnificent appendage in order to lengthen out an Alexandrine line of mighty honors. Every man who practices physic or surgery, or undertakes to tinker in any way the human body, is called Doctor. Even the village apothecary and culler of simples; and then Gentleman is most liberally applied to the Dii minorum of this title-loving people, who seem to be anxious to keep constantly out of view the distich of old Chaucer,

"When Adam delv'd and Eve span, 'Then there was no gentleman."

Mr. Granger informs me that at the first establishment of the present national government a strenuous attempt was made to introduce high sounding titles. It was proposed to style the President, His Serene Highness-the Vice President, His Highness-Senators, The Right Honorab!e-. 
Representatives, The Honorable, Exc. \&c. For the honor of the country, this ridiculous efinrt was overruled by the good sense of the nation. Drawing rooms, levees, regulations of rank and prescriptions of etiquette, are however, permitted to disgrace the government; and questions of high import, and of great pith and importance, with respect to precedence, are debated with wonderful zeal and astonishing ability. Shall the wife of the President return visits-shall the wife of a Secretary pay the first visit to the wife of a member of Congress-shall the Secretaries outrank the Senators-shall clerks and the wives of clerks visit the President's drawing room-are questions which have been discussed in solemn council, and which have employed every tongue and every mind in the sublime Bagdad of America. A litthe more than two hundred years have elapsed since the first settlement of this country; and as a generation averages but thirty-three years, few jamilies here can boast of more than five generations; and yet our ears are saluted in all quarters with panegyrics on great families, who have come perhaps

"From Greenland, Zembla, or the Lord knows where."

I assure you that I feel infinitely disgusted at this ridiculous apery of nobility. I have seen 
enough to know, that the true noble is the noble of nature, and that the really great man is the man who stands on his own legs, not on the crutches of his forefathers: who relies on his own intellectual and moral powers, without any wish to climb into consequence over the tomb-stones of a venerable ancestry.

"Nam genus et proavos et quæ non fecimus ipsi.

Vix ea nostra voco."

Let me not be misunderstood, as undervaluing the advantages of a respectable family. What I censure is the absurd pretensions of little men to resolve themselves into great men by a species of genealogical alchymy. It is not a little amusing to see the efforts of a novus homo, (as styled by the old Romans) to attain the 'vantage ground of honour, formerly occupied by the ancestors of these pretenders-and the ridiculous counter exertions of this factitious nobility in endeavoring to bairicade the advances of their antagonists by a line of genealogical trees. I accidentally lit on a rare book in five octavos, in petto, styled Alden's Epitaphs, \&c. where I found the lineal and collateral consanguinities and aftinities of some families arranged with so much precision, and their remote ramifications laid down with such perspicuous delineations, that I was alınost tempted to believe that I had stumbled on the Britisls 
Pcerage. Ages, marriages, children, narrieș, sitếs. professions, offices, follow each other in the true nobility style.

" Stuck o'er with titles and hung round with strings,

That thou may'st be by kirgs or w-s of kings ;

Boast the pure blood of an illustrious race,

in quiet flow from Lucrece to Lucrece :

But by your father's worth if your's you rate,

Count me those only who are good and great.

Go ! if your ancient but ignoble blood,

Has crept through scoundrels ever since the flood,

Go! and pretend your family is young,

Nor own your fathers have been fools so lcrig.

What can ennoble sots, or slaves, or eowards?

Alas ! not all the blood of all the Howards."

When I was on the canal, I frequently associated my views with moral considerations, and strayinto allegorical representations in the John Bunyan style. When I saw some boats ascending the locks-others descending, and many keeping on in the even tenor of their way, I witnessed a true picture of human sooiety-which constantly exhibits the rise and fall of individuals, and a vast assemblage of contemporaneous, concurrent and counteracting exertions to attain felicity and glosy. With most men it is much easier to pull down those above them, than to aseend to the same level. The political ostracisms of the Grecian democracies, and the banishment of illustrious men in the Roman republic, are a severe 
satile on human nature. I have often traced a resemblance between the ancient Athenians and the modern French-lively and full of mind, adoruing the world by the works of art and the proauctions of genius-but yet cherishing a personal vanity, which constantly puts them in a belligerent state with men of superior merit, and a national vanity which creates the same collision with all other nations. At one time the Grand Monarque, and at other times, the grand Nationthe Grand Emperor-the Grand Consul-and always, the glory and the greatness of the world.

\section{LETTER XIV.}

Canandaigua, June, 1820.

My Dear Sir,

In every country or village inn, the bar room is the cofice room, exchange, or place of intelligence, where all the quidnuncs, newsmongers, and politicians of the district resort, and where strangers and travellers make their first entry. Neither my taste, my habits, nor my convenience will admit of gorgeous or shewy equipments, and when I therefore take $m y$ seat in the caravanseras, there is nothing in my appearance to attract 
- particular attention. Many a person with whom I have held conversations, has undoubtedly forgotten the subject, as well as the company. In the desultory and rapirl manner in which such conferences are generally managed, a stranger is liable to mistake names and titles of office. I have 10 doubt hut this has been my case frequentJy: I may have styled a major a colonel, and a sheriff a judge, and if so, I assure you without the most distant idea of giving offence.

"Curs'd be the verse however sweet it flow,

Which tends to make one worthy man my foe;

Give virtue scaudal, innocence a fear,

Cr from the meek ey'd virgin draw a tear."

Tolney told me in Paris, that he travelled all over the west on foot. My countrymen Dr. M'Nevin and Dr. Goldsmith, perambulated a great portion of Europe; and Wilson, the father of American Ornithology, was almost always a pedestrian traveller. How cautious ought people to be when in company with strangers. I have heard folly from the mouths of lawgivers, and ribaldry in the conversations of the notables of the land.' Unnoticed, unobserved, reclining on my chair in the bar room, I have seen human nature without disguise-the artificial great man exhibiting his importance-the humble understrapper listening like a blacksmith to a tailor's 
news-the oracle of the place mounted on lis tripod, and pronouncing his opinions with solemn gravity. 0 ! if I had been recognized as a traveller from the eastern world-a keen observer of human naiure-and a recorder of what I saw, I humbly hope that much nonsense would have been spared, and many improper exhibitions prevented; but then $I$ would have seen man at a masquerade. I now derive light from my obscurity, and observe this world as itis. My plain dress, my moderate expenditures, my unobtrusive behaviour, avert particular remark. It is only in the society of such men as I meet with in this place, that I am considered as of the least importance. The prevalent conversations all over this federal republic, are on the subjects of political excitement. After some sage remarks on the weather, which compose the exordium of all conversations, the man of America, like the man of Athens, asks, What nows? It is needless to say, that I have steered entirely clear of political and theological strife. I hardly understand the nomenclature of parties. They are all republicans, and yet a portion of the people assume the title of republican, as an exclusive right, or patent monopoly. They are all federalists, that is, in favor of a general government-and yet a part arrogate to themselves this appellation to the disparage- 
ment of the others. It is easy to see that the difference is nominal-that the whole controversy is about office, and that the country is constantly assailed by ambitious demagogues for the purpose of gratifying their cupidity. It is a melancholy, but true reflection on human nature, that the smaller the difference the greater the animosity. Mole hills and rivulets, become mountains and vivers. The Greek empire was ruined by two most inveterate factions, the Prasini and Vineti, which originated from the colour of livery in equestrian races. The parties of Guelphs and Gibbelines, of Roundheads and Cavaliers, of Whigs and Tories, continued after all causes of difference were merged. I have often asked some of the leading politicians of this country, what constituted the real points of discrimination between the Republicans and Federalists, and I never could get a satisfactory answer. An artful man will lay hold of words if he cannot of things, in order to promote his views. The Jansenists and the Jesuits, the Nominalists and the Realists, the Sub-lapsarians, and the Supra-lapsarians, were in polemics what the party controversies of this people are in politics. If you place an ass at an equal distance between two bundles of hay, will he not remain there to all eternity? was a question solemnly propounded and gravely debated by the school- 
men. The motive to eat both, some contended, being equal, it was impossible for the animal to come to a conclusion. He would therefore remain in a state of inaction, for ever and for ever. This problem, so puzzling to scholastic philosophy, would at once be decided by the ass, and the experimentum crucis would effectually silence every doubt. It is impossible for a man, however quietly disposed, to act the supposititious part of the scholastic ass, and remain neutral between the parties, or bundles of hay. He must in truth participate in one or in both, and as it respects any radical difference of principle, it is very immaterial which he selects. There are some pendulum politicians who are continually oscillating between parties, and these men in endeavoring to expiate their former oppugnation by fiery zeal, are mere fire-brands in society. In order to cover their turpitude, they assume high-sounding names, and are in verity political partizans, laying claim to be high-minded, and like Jupiter on Olympus, elevated above the atmosphere of common beings. And what adds infinitely to the force of these pretensions, is to find the most of these gentry to be the heroes of petty strife, and the leaders of village vexation, the fag ends of the learned professions. and the outcasts of reputable associations. I often think of the observations of the honest old? 
travelier, Tounefort, when I see the inordinnte violence of these high-minded gentlenen. "The Turk, (says he) take 'em one with another, are much honester men than renegadoes; and perhaps it is out of contempt that they do lict circumcise. renegadoes: for they have a common saying, that a bad Christian will never make a good "Turk."

\section{LE.TTER XV.}

\section{MY DEAR SiR,}

Canandaigua, June, 1820.

Every country strilies a traveller by the appear. ance of some strange phenomena or uncommon exhibitions-and the novelty of the spectacle impresses him sometimes so deeply, that he is apt to over-rate its importance. In travelling on the canal, I heard for the first time, the sounds and cries of strange animals, and perceived sights which I had nover witnessed beforc.

The conntry appeared in the night time full of sparks of fre in continual motion. It was easy to anderstand that these were the phosphoric emissions ofinsects on the wing. I accordingly caught some of the strangers and found them to be a specics of lampyris; I belicve the lampyris corrusca 
of Linnerus. This insect does not existin Europe but is to be found in Japan. The lampyris noctiluca, or glow worm, is quite a difierent animal, and is the same in this country as in Europe: The female is apterous, while the male is of the coleoptera order, having four wings, and the upper wings crustaceous. The female emits the light, and the male is guided by it to its paramour. This anomaly is striking. As the female has no wings and is confined to the earth, nature has furnished her with a lamp to direct her winged partner to the nuptial couch.*

Next to the fire fly, the most striking nocturnal object is the rana pizpiens or bull-frog. The roar of this animal is unknown to a stranger. He is unknown in Europe-and a repetition of the coarse and lugubrious cry of these animals, res-

* The following lines from Southey's Madcc contain an excelJent description of the Americars fre fly:

Sorrowing we behe?d

The night come on; but soon did night display Fifore wonders thein it veild: iantmerous tribes

From tlee wood-cave swarn'd, anci darkness made

'The $r$ branties visible : one while they strean'd A bright blue radiance upon flowers that closed Their gurgeous colors from the eye of day ;

Now molion!ess and ricthi, elualed search, Self.shrouded: and anon, starring the sky, Rose like a sizower of fire. 
ponding as it were to each other, like the alternate crowing of village cocks, is calculated to make a strong impression. Whether this is the call of love, the shout of superiority, or the cry of - battle, I do not know ; but if this be a fighting animal, I should think that these tremendous sounds must be the heralds of approaching battles. In countries surrounded by steep hills, the bull is made extremely ferocious by the echo of his own bellowing: In this case the bull-frog must be sufficiently excited by the noise of hundreds of antagonists in every considerable collection of water. In addition to this I sometimes heard the noise of the rana arborea, or tree-frog; and a sound like the noise made by the cat-gut of a fiddle when tried by a musician. This proceeded from a frog which I saw frequently on the canal and which in my opinion is a non-descript, as I do not believe it to be the rana boans, or croaking frog of Europe.

The interest of this nocturnal scenery was greatly heightened by the melancholy cries of the caprimulgus virginianus. Its name, whip-poor-will, is derived from its noise, which is undoubteily the sigual of assignation. It difiers specifically from the European goat sucker. The Indians consider. it a bird of evil omen, and that if light on a house: the death of some of the inhabitants is inevitable. 
I also heard from marshy or watery places a mixed sound or concert, which was incessant and unvarying-neither pleasant nor disagreeable, but increasing, upon the whole, the solemnity of an American night by the variety of its music. This I was told was the work of frogs ortoadsbut of this I must confess that I entertain doubts. May it not have proceeded from animals of the lacerta kind ?

On the canal I saw in the day time continually on the wing, and in pursuit of prey, a species of libellula, or dragon fly, which is vulgarly called the devil's darning needle. The female drops her eggs into the water, which are hatched into larvæ, or caterpillars-and they continue in that and the pupa state two years before they emergc complete insects. This ravenous insect is in turn preyed upon by hirundines. The martin or hirundo purpurea, feeds its young with it, and the ground below its cage is covered with its mutilated wings and members, scattered about like the broken remains of dead bodies in the den of Cyclops. The curious insect which prepares a place of deposit for its ova by rolling dung into balls, is sometimes to be found in this country, and its unremitting industry in its dirty operations, reminds one of the incessant abuse of the scurrilous blockheads which infest the republic of letters. 


\section{LETTER XVI.}

Canandaigua, June, 1920.

My Drar Sir,

Acr wool that is susceptible of a fine polisin, will make good furaiture, and where the texture is compact, and the grain fine and concentrated, a pulish can be made, an almost invariable accompaniment. I have been not a little surprised at the extraiagance of the Americans in importing malsogany, satin wood, \&c. for cabinet work, when they have as good, if not better materials at home. I find cabinet makers in full employ all over this country, and it is an occupation which deser:es encouragement. It adds greatly to our comfort to sit down at a table which reflects lilie a mirror-and I always judge of the house-wifery of the lady of the mansion, by the appearance of the side board and tables. $A$ man of observation will form a judgment in this respect by a single glance, apparently without taking any notice, and certainly without a scrutinizing stare: All young ladies that are candiclates for matrimony ought to understand that they cannot place too much 
stress upon observances of this nature. No man who has any regard for his own comfort, will marry a woman who does not pay attention to cleaniness and neatness, which indeed were so high$3 y$ prized by the Stagyrite, that he arranges them in the class of semi-virtues.

"__E'en from the body's purity,

The mind receives a secret sympathetic aid."

But to return to my subject. I went yesterday to a cainet maker's shop, and I was surprised at the variety and elegance of the furniture, chairs, and side boards, tables, book cases, and bureaus, of walnut, maple, and wild cherry, which would with a competent polish excel the furniture made of imported wood.

In the first place, a species of the acer, or maple, which grows all over the country, is the material from which some of the best cabinet ware is made. This wood in growing, frequently receives a curions kind of contortion, from which it derives its denomination of curled maple, and it sometimes is shaped into a formation singularly elegant, called Lirdseye, from its appearance. Independently of its uses in this respect, this maple mansplanted into the court yard, and along the fences, in rows or in clumps, makes a beautiful ornamental tree.

The juglass nigra or black walunt grows to an immense size and malice firm cubinet work. 
The nut is a fine addition to the table. The primus virginiana, or wild cherry, is equally good, if not superior; and nothing but attention to polish is wanting to render furniture of this kind equal to any imported. The berries of this tree put in spirits make a salubrious drink. I have no doubt, but that other wood of excellent adaptation to the purposes of furniture, will be discovered. Mahogony was not introduced into use until 150 years after the first settlement of Jamaica.

Pownall, in his topographical description of North America, states it as the opinion of his friend Mr. Pratt, that the juice which can be drawn by incision from the poison vine is that material which the Chinese and Japanese make their verjuice with. This is the rhus miscrocorpar of Pursh, and is probably confounded with the rhus vernix which is adjudged to be the true varnish tree described by Kompfer in the Amænitales exotic by the name of sitz-dsin, and which grows all over this country as wcll as in Japan.

In a word, my dear sir, the people of America are furnished, by the bounty of heaven, with every accommodation and comfort, and with a copious supply of the utile dulci. Their artisans are ingenious and industrious - their materials for fabrics abundant in quantity and good in quality. Why then should they resort to the workshops of 
Euroje? Why should they seek for the materials of manufactures in foreign countries? It is as absurd as for a man to look for happiness in ta. verns, bagnios, and gambling houses, when he has a lovely wife, promising children, and every comfort at home.

I have received but one letter from you since my arrival in this place. Hence I infer, though perhaps unjustly, that my communications are uninteresting to you. Shall I be more sparing of them in future? I submit to your reprimand, because I deserve it, about my noticing the literary Jack puddings and Charlatans of the day. They are really hors de combat in every respect.

"Sons of a day, just buoyant on the flood,

Then numbered with the puppies in the mud."

\section{LE'TTER XVII.}

Canandaigua, June, 1820.

Mit Dear Sir,

Is borrowing a sentence from a living author of some note, I think that its application to this country is pecnliarly felicitous. "In the remotest village there is a nucleus round which the capabilities of the place may chrystalize and brighten." In every place there is a brilliant star, if not a 
constellation, of enlightened men-men who devo:e themselves to the "silent progress of study, and the placid conquests of investigation." It is pleasing to observe the respect with which these men are treated by their fellow-citizcns. Moral and intellectual strength and beauty are in this country the companions of political importance and influence. This I admit is not invariably the case. Some persous of uncommon worth and extraordinary endowments are now sufering a political ostracism; and there are now many men high in office who answer the description of Cicero-" Ad honores adipiscendos et ad rempublicam gerendam uudi veniunt, nulla cognitione rerum nulla scientia ornati." In Europe the partition wall between the different classes is maintained and fortified by the habitudes of society. The great man there always travels in his own coach or barge, and if lie royages on the sea, he takes the whole cabin to himself. Here the head men, or primates of the country, travel with their families in stage coaches, in steamboats, and in canal-barges, and think it no degradation to sit down at the public rable, and to converse kindly and familiarly with all. The consequence of this felicitous commuuion is a growing and expanded improvement in the decorums of life, and in the progression of mind. Prejudices are removed-animosities are 
softened-and the links which connect the chain of human society are strengthened and brightened

Much of the happy state of this great community may be justly imputed to the influence of the female character. A late traveller says that the United States are governed by an oligarchy of Gazette editors. In no country are the formen held in higher respect, and I intend no offence when I contradict this assertion and say that a gynecocracy prevails: Go into the most common farm house, and converse with the sous and daughters of the family, and you will find something that pleases in the manner of the latter, while the former fiequently require the ascendancy of an Iphigenia to polish the bluntness of their de. meanor.

I frequently spend whole days in traversing on foot this beautiful country, chequered with enclosures-crowned with trees-filled with housesteeming with vegetation, and smiling with plenty; and when I reach the high hills of Bloomfield, I appear to breathe a balmier air, to bchold a serener sky, and enjoy a brighter sun. But in my peregrinations I never lose sight of man-I look at him in all his varieties and aspects-in his insulations and in his associations. The women of this country, after performing the labors of the hay, amuse themselves in the afternoon by giving 
or receiving visits, and you invariably see then as you pass their houses at that time, clothed in neat and decent attire. Groups of children are to be scen at the doors, rising in regular gradation, like the steps of a pyramid, enjoying the smiles of parental affection, and eyeing the passing traveller. When I view these scenes of domestic bliss, I feel something come over my heart which draws tears from my eyes. These excellent women have never visited the Castle of Indolence-they know not the place where

"Languid beauty keeps her pałc fac'd court."

And they dread those associations,

"Where far is cast the distafi, spinning wheel, and loom, Where the sole labor is to kill the time;

And labor dire it is, and weary wo,

Or saunter forth with tottering steps and slow."

When I render the just tribute of applause to the general character of this interesting people, I cannot conceal my disapprobation of some noxious habits which generally prevail. In my whole tour I do not think I have seen more than three travellers on horseback, and those wore umbrellas over their heads : It seems that a scraggy, ricketty, one-horse waggon, has been substituted-that it was introduced by a General a few years ago, who was too fat to be an equestrian. Of all exercises, riding on horseback is the most healthy and 
manly;, A favourite author says, "I consider the absolute resignation of one's person to the luxury of a carriage, to forebode a very short interval between that and the vehicle which is to convey us to the last stage." The Americans are not an effeminate people, and it is to me passing strange that they should give in to such degenerate habits.

When a stranger alights at a tavern, he fiequently witnesses a rapid collection of idlers in the bar room, who congregate together like birds of passage in autumn, to gather news, to kill time, and to drink whiskey. I have not been able to restrain my indignation at such an inexcusable waste of time. Whenever I see it I augur ill of the morals of the place, and when I do not observe it, I mentally exclaim :- "This village is devoted to industry and teinperance" - and I frequently an induced to spend some time in it, when I almost invariably find that my judgment is correct.

\section{LETTER XVIII.}

Canandaigua, June, 1820.

My Dear Sire,

At the house of the respectable and wortlyy Mr. Greig of this town. I met for the first time with 
the ornithology of Alexander Wilson, in nine quarto volumes, and need I say that I am delighted with it beyond measure? He preserves a due medium between the dry technology of the Swedish, and the poetical delineations of the French school. Mark Catesby published two volumes in folio on the natural history of America, and George Edwards I think, seven in quarto. Wilson has far exceeded both, in the correctnets of his delineations, in the beauty of his colouring, and in the number of his descriptions. He has figured and described 278 species -56 of which were nondescripts.

The biography of this man would "point a moral and adorn a tale :" He had passed through all the vicissitudes of humble life-a weaver and a pedlar, and finally a village schoolmaster. In all situations respectable, and poising himself by the power of great talents, he stood upright while the wheel of fortune revolved under him.

What posthumous honors have been paid to this great man-what monument has been erected to perpetuate his name? None-none; and if he were now alive, he might say with the old Roman, "Malim ut de me quarant homines, quam ob rem Catoni non sit posita statua, quam quare sit posita. 
Catesby and Edwards made the etchings of their figured subjects-Wilson performed the drawings and the colourings of his-in all respects he is superior.

I am happy to agree with this great naturalis: about the brumal retreat of the swallow. He scouts the idea of their retiring into the bottom of rivers and lakes so generally credited by the disciples of Linnæus. In addition to the swallows I mentioned to you before, he has described a green, blue, or white-bellied swallow, under the name of hirundo viridis. He calls the barn swallow hirundo Americana, and seems to think that the American bank swallow, or sand martin, (hirundo riparia) is the same as the European. Myriads of swallows, says a late traveller, are the occasional inhabitants of Honduras. This is a key to the whole mystery of their winter quarters.

The second volume of the Harleian Miscellany contains an essay written scriatim, to prove that the moon is the hybernaculum of birds of passage.

- The following text from Jeremiah is the grom l work of this strange hypothesis. "The stork in the heaven knoweth her appointed times, and the turtle, and the crane, and the swallow observe the time of their coming." He says that "divers of" ibese fowls which matie such changes, and observe 
their seasons, do pass and repass between this and the moon, which is the nearest concrete or rarthly body of the planets.

That no man has seen the birds out of their seasons, and therefore he concludes they are no where on this earth, for de non cntibus ct non apparentibus eadem cst ratio.

That wood-cocks, upon a change of wind to the cast, about All-Hallows tide, will seem to come all in a night, for though in the former none are to be found, yet the next morning they will be found in every bush-that then its flesh is short and tender, whereas, after it eats, it is stringy and of a fibrous Пesh, as other of our fowls are.

The storks in Holland all collect in Harlem, near where they continue some days, and then ascend in a spiral fight out of sight.

That the word in heaven has reference to the place of flight.

He reckons a bird going at the rate of 125 miles an hour, can get to the moon in two months - that after getting up a certain distance, they may be in a kind of sleep which may supersedé the use of food.

But if the moon is too far, he concludes that there may be some concrete bodies at a much less distance, or ethercal islands invisible to us, and yet no further off than these birds may convenient- 
ly arrive to. "This I do suggest, (says this great philosopher) because it is as hard for me to persuade myself that they come from any other part of the earth, as it is to persuade another that they come from the moon, and therefore if the moon will not be allowed, some other place must be found out for them."

'This lunar doctrine is an excellent satire, altho" not intended, on the hypothesis of submersionboth are equally unfounded and equally ridiculous. The swallow is the swiftest bird that flies - a mile a minute is a reasonable calculation.In two days your swallows can reach Africa, but I do not believe that they extend their tour be: yond Spanish America, and the opposite islands.

Have you ever seen the beautiful ode of Anacreon on the swallow? Will you accept of it in translation?

"Once in each revolving year,

Gentle bird we find thee here.

When nature wears her summer vest.

Thou corn'st to weave thy simple nest ;

But when the chilling winter lowers, Again thou seek'st the genial bowers Of Memphis, or the shores of Nile, Where constant hours of verdure smile."

Edwards has given a deliacation of the Canada goose a.t large. Catesty has figured the head. 
nearly to the size of life. Compare them with Wilson's, and what a difierence in his favor.

$!$

\section{LETTER XIX.}

Canandaigua, June, 1820.

My Dear Sir,

A Dog was pointed out to me, as an Indian dog which had a peculiar conformation. It had a wild aspect--a long, flat head, slender muzzle, erect ears, coarse hair, and a long, meagre body; and if I might venture to give an opinion from appearances only, I would say that the Indian dog. was originally a hybrid produced from the union of a wolf and a fox. The internal structure of these animals is similar to that of the dog., and there is a great sameness of external appearance.

Dr. Robertson has said that the red men of America had not tamed any animal. This is not true. The dog was domesticated by them and used in the north western tribes for draught as well as for hunting. In some of the south-western nations, the wild turkey and some other birds were domesticated; and in Peru, several animals were reclaimed from their wild state. 
It is not a little astonishing that the natural history of so important an animal as the dog should be involved in so much obscurity. Some naturalists suppose that he is a distinct species; others consider him as a derivative from the jackall, the hyena, the wolf, fox, and their commixtures; and I have no hesitation in saying that $I$ am inclined to the latter opinion. The most astonishing fact in zoology is, that the offspring of distinct animals, having different periods of gestation will be fruitful.

The canis familiaris, or domestic dog, is gravid from 60 to 63 days. The wolf 100 according to Shaw, and 70 according to others. The jackal 30 days, and the arctic fox 63 ; aud yet there is no doubt but that the hybrid of the wolf and dog will produce offspring.

In like manner the gyall or bos fontalis of the East Indies, is gravid eleven months, and the domestic ox and American bison or buffalo, nine months; and yet they will have a fruitful race.

Bufion placed the wolf and female dog together, and also the fox, and yet they had no connexion. The experiment however was not a fair one. Wild animals, particularly the wolf and fox, when caught lose their activity and spirits, and pine away. Linneus enumerates 11, and Bufion 30 fixed varieties of dogs, and some of them are as 
dissimilar as it is possibie for animals of the same genus to be. What can be more unlike than the lap-dog and the mastiff-the Irish grey-hound and the common cur.

The Indian dog which I saw was accompanied by his red master, and it immediately brought to my mind the beautiful lines of Pope.

Lo the poor Indian! whose untutored nind Sees God in clouds or hears him in the wind;

His soul proud science never taught to stray

Far as the solar walk or milky way :

Yet simple nature to his hope has given,

Behind the cloud-topt hill, an humbler heaven--

Some safer world in depth of woods embrac'd,

Some happier island in the watery waste,

Where slaves once more their native land behold,

No fiends torment, no Christians thirst for gold.

To be, contents his natural desire,

He asks no angel's wing, no seraph's fire;

But thiuks, admitted to that equal sky,

Iis faithful dog shall bear him company.

St. Pierre well observes, that the dog is a true friend, and the cat a courtier-the former is attached to the person, and the latter to the house of his, master; and Bufion concludes his splendid panegyric on the dog, by pronouncing that "he is the only animal, whose natural talents are conspicuous, and whose education is always successful."

When Ulysses, after an absence of twenty years, zeturued to his home in the garb of a beggar, al- 
though no: recognized by his faithful wife, or domestics, yet his old dog Argus immediately knew his master, and expired in a paroxysm of joy. What a striking eulogium on the sagacity and fidelity of the dog! how true to nature, and how worthy of the Prince of Poets: it is the most pashetic scene in the Odyssey.

\section{LETTER XX.}

Canandaigua, June, 1820.

MY DeAr SIR,

$\Lambda$ LATE English traveller, who published a book of travels, and who calls himself John Cam Hobhouse, has declared in the true John Bull style, when smarting under the privations and sufferings of a barbarian country, that "properly speaking, the word comfort cannot be applied to any thing he ever saw ont of England." 1 have travelled inuch, both in the United States and in Great Britain, and I can truly say, that making allowance for the difference in price, and the newness of settlement, the accommodations are not superior in the latter. 'The unhappiness of life frequently proceeds more from a series and repetition of petty vexations, than great and overwhelming calamities, and these miseries in minia- 
ture are firequently occasioned, if not aggravated by the ucglect of small observances and attentions, and by the disquietudes which irregular and disorderly men continually produce. A custom peculiarly American, is to lean back on the chair with extended legs. I never saw an European practice this impropriety. The practice of drumming with the fingers, as if practising on a harpsico:d, on chairs, sofas and tables, is so prevalent, that $I$ am almost inclined to pronounce the Americans a musical people. Again, the handling of forks, and knives, and spoons, and plates, at table, when not in use, evinces the activity and sprightly habits of this ever stirring nation. Travelling incog. I have passed myself off as a person who wants to buy a tract of land. This has been rumoured about the country, and persons are continually teazing me with proposals to sell : and these interviews are accompanied with searching questions, which reach not only to the bottom of my business, but to the history of $\mathrm{my}$ whole life. I verily, believe that a witness in a court of civil law, never underwent a more sifting examination than I sometimes experience. The visitor generally opens the conference by proposing to trade for land, and perhaps we may swap farms - and then he digresses into a long enquiry about my age, nativity, country, family, business, 
politics, religion, \&c. \&c. which generaily consumes two hours. If I can escape with an hour's andience of this kind, I think myself well off-and all this is managed in a style so truly diplomatic and respectful, that it is impossible to take oflence. A direct interrogatory is rarely put, and I sometimes amuse myself by bafiling the question, and increasing the impatience of unsatisfied curiosity. For instance, I frequently apply a negative to every question. Did you come from France, sir? No. From Holland? No. From England? No. From Scotland? No. From Ireland? I can't say. From the West Indies? I don't know. From Mas sachusetts? No. From Nantucket? No. From Cape Cod? No. Then, exclaimed the impatient inquirer, where in the world did you come from? From beyond the Atlantic, sir. This silenced the man for some time-but again he rallied his forces, and presented his questions in another shape. Let me see, said he, you have somewhat of the tone of a Yorkshire man, or a Scotchman. May be, sir. Is it true, said he, that the potatoes of your country, Ireland, are better than ours? Humph--said I. How long were you coming from Cork, sir? Humpli-said I. Is your sovereign, George 4 th, as wise as his father? Go and see. Did you see counsellor Sampson, your countryman, in New-York? Yes, said I, but I do not admit that I am an Irishman. Do you know Gideon Granges 
and Nathaniel Gorham? Perhaps so. Were you ir: this country during the last war? My patience could stand it no longer, and I took up my hat, and excused myself by saying, that I had particu lar business, and must take a walk.

The inns are generally comfortable, clean, convenient, and well supplied with provisions; but still there is room for improvement, and many little accommodations are overlooked. I have seen bells no where but at the great inn at Geneva, and scrapers no where but at the sign of the whale in Chitteningo. 'There are few carpets, and instead of blinds on the inside or outside of the windows, to exclude heat and excess of light, the windows are generally curtained with a coarse kind of paper, which is as dificult to move as a fifty-six, and which is constantly rattling about your ears like hail: and by the by, in the best private houses, you frequently see papered rooms, which serve as an asylum for bugs and other vermin, instead of painted or stained apartments, which never admit them: and when you go to rest you plunge in to the gulf profound of a Scandinavian feather bed, from which it is difficult to retreat, and in which it is still more difficult to move.

The prices of travelling in stages, and of living in some hotels are too ligh, when compared with 
the general fall of commodities and wages. It is true that the horn of plenty scatters its blessings in profusion. Your breakfast and tea table is ovcrloaded with cakcs, green cucumbers, pickled cucumbcrs, cheese, sweatmeats, and sallad, besides more agreeable viand's; but then the coffee is sometimes burnt (not roasted) so that the aroma escapes; or you have the deleterious green tea instcad of black-and instead of wholesome bread, you are served with a mixture of flour and inilk, which is really disgusting; because as soon as the latter ingredient acidifes, it taints the whole mass, and offends the smell as well as the taste. The bacon and eggs, at dinner, and the broiled chickens and real cutlets are very fine. You have good beer and cider-fine wine is rarely to be got. And in this country of cheap timber, the ice houses are comparatively rare.

When you call for a meal, you are frequently surprised to find yourself surrounded by strange travellers. This is a contrivance of Madame 'Traiteur to save tronble-and then it is considered an essential etiquette to place a neatly dressed female at table, to preside orer its ceremonies, and to pour out the coflec. 'This is frequently very agreeable, and you are often pleased with the conversation of a modest, sensible young iroman. 
The principal signs of taverns are descriplive of the genius and feelings of a people. In this country, the bald eagle, the symbol of national glory-the implements and products of agriculture, the signs of national wealth-and masonic figures, the emblems of national charity, adorn the inns. Sometimes you meet with a whale, a lion, or a horse-but where do you not see unmeaning and absurd exbibitions?

The weather is extremely hot: so much so, that I can hardly think or write. A man generally observes through the medium of his feelings. When you are overwhelmed with fatigue, oppressed with heat, or overpowered with cold, how can you sce accurately, or describe justly? Is not this the true key to most of the nonsense and fable of travellers?

\section{LETTER XXI.}

My Dear Sir,

Is attempting to describe the great water communications of this region, I am seusible that I have undertaken a task which far transcends my faculties. An elegant poet has truly said "None but a Phidias should attempt a Jove.' But as you have considered my letters with kindress, I 
shall not be deterred by my acknowledged incompetency from gratifying your wishes.

It appears to me that in seasons of great heat, a change of water is as essential to health on canals, as a change of air is in houses. Fresh water is as important as fresh air : and whenever this is neglected, the banks of canals will exhibit the same diseases as the country in the vicinit, of any other stagnant waters. A considerable part of this canal runs through a region of gypsum which it is well known consists generality of 32 parts of lime, 46 of sulphuric acid, and 22 of water. These component parts may indred differ in different species and varieties, and gypsum sometimes contains foreign ingredients, such as alumine, iron and silica. The principal constituent, being sulphuric acid, and this substance, which is commonly called oil of vitrol, and which is derived from sulphur and oxygen, being necessarily unwholesome, will communicate its qualities to the canal in the most deleterious manner, if the water is left in a stage of stagnation. BCsides this, the water will by freqnent cliange be supplied with fresh solutions of lime, which will have a tendency to neutralize the miasmata of vegetable putrefactions. In old stted countries, rapid streams are an indication of salubrity, but in this western region, where the waters are in. 
pregnated with vegetable decompositions, it is remarked, that at places of great precipitation of this fluid-at great falls, which increase the rapidity of its motion, bilious and malignant fevers are inore prevalent, because more miasmata are brought into activity, and infused into the atmosphere, and this evil will continue until cultivation prevents the supply of vegetable putrefaction. I am therefore pleased at hearing that new feeders have been provided. You may recollect that in a former communication, I told you that I would give you my view of the causes of the late freezing and early thawing of the waters on this canal. This is owing, in my opiniou, to the abundance of sulphuric acid in it. It is well known that water and sulphuric acid combine so intinately and closely, that the compound gives out a large portion caloric. Four pounds of this acid, mixed with one pound of water, will raise the thermometer to 300 degrees of Farenheit. There are undoubtedly auxiliary, as well as counteracting causes which act in relation to the greater heat of the canals.

'I'he canal will however have a most beneficial cffect in increasing the healthiness of the country. It will act as a great drain to carry off the sedundant waters, and to dry up the sources of pesti. lence. 
In my opinion, the period of the greatest unhealthiness of a country, is the intermediate state between a state of nature and a state of cultivation. The felling of trees produces vegetable decomposition, and opens the earth and the water to the action of solar heat. Evaporation and exhalation are augmented, and poisons which were before inert and inactive, are excited into deleterious activity. The Python of the ancient mythology was intendied to represent the terrible miasmata of this or an analogous state. Ovid thus speaks of the events which immediately followed the deluge,

\footnotetext{
Ergo ubi diluvio tellus lutulenta recenti Solibus æthercis altogue recanduit æstu, Edidit enumeras species: partimque figuras Tietulit antiquas: partim nova monstra creavit. Illa quidem nollet, sed te quoque, maxime Python, Tum genuit ; populisque novis, incognite serpens, Terror eras: tantum spatii de monte tenebas.
}

The influence of cultivation was personified in Apollo, who slew the serpent.

Althongh the clearing of a country does not create new beings, yet it multiplies their number, and augments their power of good and evil. The food which is furnished to the voracity of insects, and the heat which is administered to their propagation and growth, are increased by settlement. dan-the usetul creatures by which he is surroun- 
ded-and the beneficial regetables which he introduces, invite the annoyance of this tribe of beings; and the great numbers of some invariab) $y$ indicate an unhealthy state of the atmosphere: and in some degree contribute to it.

Respice finem. The diseases which necessarily follow from the clearing of a country will be inputed to the peculiar malignity of this canal. Is there not in human nature a diabolical spirit which delights

"to damn and to destroy ?"

What pleasure can be derived from the defacement of milestones-the prostration of monuments -the destruction of aqueducts? - and yet, go where you will, and you will see the ravages of Vandalic fury. I have just been told that a ruffian was caught in destroying the banks of the canal. The state prison will be his destiny. But in the eye of morality and patriotism, is not the wretch equally culpable, who endeavors to arrest this great inprovement, by poisoning the public mind-by calumniating its patrons-and by circulating false reports about its stability and usefulness. 


\section{LETTER XXII.}

MY Dear Sir,

Canandaigua, July, 1820.

I was yesterday informed that there is a burning spriug a few miles from this place, and 1 immediately set out to view it. I soon found it about eight miles to the southwest of Canandaigua, in a district of country called Bristol. A small stream flows at the foot of a hill about 30 feet high, and contains pure water, and small fish 'The gas bubbles up in the water through spiracula, and also issues firom the dry ground adjacent. In the first place it appears like boiling water, and in the last place it is in a state of flame: It smells like the smell of a lamp, without a rank, unctuous quality, and burns like the flame of a candle, or ignited wood, or coal, and it is sometimes in a state of ignition the greater part of the year. It was discovered accidently by a man clearing land on the hill ; a brand fell down and ignited the gas which issues through many spiracula or apertures.

The stone in the vicinity is shale, and sometimes contains a small calcareous mixture, as is evident from its slight effervescence with sulphuric acid. On my return to this place, I was told ,hat a similar spring has been discovered near a bed of gypsum in West Bloomfield, and five or 
six in Richmond, south-west of the one I visited; both these districts border on Bristol. There is also a burning spring at Chippeway, in Upper Canada, and another in Westmoreland, ten or twelve miles west of Utica, near the Seneca turnpike road. They probably exist in many places in this region, and'they appear to range from east to west, diverging a little to the south-west.

The gas which coinposes these burning springs, is carburetted hydrogen gas, or carbon dissolved in hydrogen. It is the fire-damp of coal mines, and whenever the atmosphere of a mine becomes charged with more than one-thirteenth of its volume of this gas, the whole becomes explosive. The priests who lirect the worship of the followers of Zoroaster in Persia, impose this gas, when in flame, upon their sect as the immortal fire, after having conducted it by secret con. duits into their temples.

I have been informed by a gentleman from the state of Ohio, that at Rocky Hill, in that country, about a mile and a, half from Lake Erie, an attempt was made to bore the earth for salt. After proceeding to nearly the depth of 200 feet, the auger fell, and salt water rose through the aperture, and played for several hours. After the water was spent, volumes of inflammable air issued Eorth for a long time, and formed a cloud, which, 
communicating with the fire in the workmen's shops, became ignited, and consumed every thing in the vicinity. Large quantities of coal are close by.

Hollinshed states in his Chronicles, that at the time of a great earthquake in the reign of Henry I. "fire burst out of certain rifies of the earth in so huge flames, that neither by water nor otherwise could it be quenched." And Southey spcalss of sea-fires which rose from the sea, travelled into the interior, and consumed many towns. These undoubtedly proceeded from large collections of carburetted hydrogen gas, extracted from the bowels of the earth, and put in a state of ignition.

As this gas is partly generated from carbon, the principal constituent of coal, it is an almost certain indication of a coal minc. I admit that it is not an infallible one, and that it may be extracted from other substances, but this can rarcly, if ever, occur in large quantitics. The actual existence of coal at Rocky Hill, and of shale, the roof of coal mines, at Bristol, justify beyond question the correctness of my conclusions.

Here then is an important developement, which, in connexion with a preceding letter, shows satisfactorily the existence of conal throughout this region. Bituninous aul sulphur springs confirm 
the impression : and the wide and extended range of these and burning springs, prove that this all important fossil is to be found in great plenty over the whole country.

\section{LETTER XXIII.}

Canandaigua, July, 1820.

\section{My Dear Sir,}

The larch, or pinus larix, takes a high rank among European trees, for the excellent qualities of its wood and bark. "The most barren mountains will grow larches," says Bishop Watson, and the experiment has been successfully and repeatedly tried in Scotland, whose bleak and rugged mountains now exhibit vigorous vegetation. From this tree the Venice Turpentine is, extracted. Taken internally, its resins are aperient, sudorific, diuretic, and stomachic; and applied externally, they are anodyne, detersive, and antisceptic.

In this country there are two species of larch, although they have been generally considered as varieties, and they are denominated tamarack, or hack-matack. The larix pendula, or black larch, is found in cedar swamps, and the larix microcarpa, or red larch, on high mountains according 
to Pursh. They closely resemble each other, but that they are specifically distinct, has been satisfactorily established by Mr. Lambert, who obse:ved, that they always keep distinct, when raised from seed.

The American larch is said to resemble the European, where there are always two species: but whether they are the same tree, I cannot distinctly say.

This tree has never becu transplanted or cultivated in this country. You now and then perceive a solitary one before a court yard. It is a beautiful, ornamental tree, and its rapid growth and adaptation to the most barren soils, recommend it decidedly to the attention of the American agriculturist.

"By cultivation," said Bishop Watson, "I mean tillage, pasturage, and plantation. The last, except for fruit trees, is totally neglected in this country. This is owing to the abundance of wood: but even already, the inhabitants of cities have been forced to import their coal from England. Every farmer ought to devote twenty acres to the planting of trees for fuel and building-and using an acre a year, and continuing to replant, the deficiency will be supplied, allowing twenty years for the growth of wood. The Hindon, who plants a tree, digs a well, and has a 
son, is sure of heaven. It is to be regretted, that some strong and similar inducement does not operate in America.

All the roads and canals ought to be lined witl forest trees. The shade will be agreeable, and the view delightful to travellers.

The Americans are a ship-building people. $\Lambda$;4, it is calculated, will take the wood of fifty acres. Is it not time for them to look out for futurity, and not to anticipate the supplies of future generations?

In passing from Rome to Syracuse, you see nothing but one great forest, which must contain many millions of cords of wood : but already have the axe and the fire-brand been applied, and before the lapse of 50 years, these immense woods will fall before the hand of cultivation. What then will become of the great manufactories of salt, unless coal is discovered, or plantation adop1ed? Both mustbe attended to-wood will always be required for navigable and architectural purfoses. The swamps west of Rome are filled with turf or peat, as I perceived from the canal packet. 


\section{LETTER XXIV.}

Canancaigua, July, 18æ0.

\section{Miv Dealr Sir,}

I saw, for the first time, in the Seneca river at Montezuma, the aquatic plant, called wild rice or folle avoine. It grow's all over the west and north-and wherever it flourishes, myriads of water fowls are attracted to it, and derive their chief support and exquisite flavour from its alimentary qualities. In the lakes and rivers adjoining Montezuma, thousands of wild geese and ducks of all kinds congregate at the proper season for food, except the canvas back duck, or anis vulisneria of Wilson, which derives its name from a water plant called valisneria, on the roots of which it feeds, and which is a fiesh water vegetatable, that grows in some parts of the Hudson and Delaware, and in most of the rivers that fall in:o the Chesapeake.

Some dificulty has occurred not only about the botanical name, but also about the botanical character of the wild rice, or wild oats. This confusion of nomenclature has arisen from Linneus himself. In his species plantarum, he has denominated it rizania aquatica, and in his Manissa, zizania palustris-and it hos been called 
by other botanists, $z$. clavulvsa-I shall prefer the first name as most characteristic. It has been well described by Mr. Lambert, as

Zizania panicula inferne racemosa superne spicata. Pursh represents it as a perennial plant; Nuttall and Michaux are silent on this point, and Eaton says it is an annual, in which opinion I concur.

Mr. Lambert, in a communication in the $7 \mathrm{th}$ volume of the Transactions of the Linnæan Society of London, has given a figure of this plant, as growing at Spring Grove, the seat of Sir Joseph Banks, in England. It appears that Sir Joseph received some of the seed, gathered in a lake, in Canada, and put up in jars of water. It was sown in a pond at Spring grove, where he has a great quantity of the plant, growing annually, ripening its seeds extremely well in autumn, and sowing itself round the edges.

By what I can learn, this same plant grows in Lake George, and Lake Champlain, and in all the Western Lahes. It produces seed in some places in September, and in others in October. It grows in shallow water, and sometimes to the heighth of eight feet. Some of the western Indians derive their principal support from it. The grain it bears is superior to the common rice, and if cut before ripc, it makes excellent 
fodder, embracing the advantages of hay and oat: Mr. Lambert's figure of the plant in the Linnæa Transactions is accurate, and exactly resembles the one growing in the Seneca river. Its productiveness may be inferred from the food it furnishes to thousands of human beings, and to myriads of aquatic animals. From the success of the experiment of Sir Joseph Banks, it is highly probable that it will grow in any part of this country and Great Britain; and if so, may it not be consider.ed as a good substitute for the oryza sativa or common rice. It is well known that the latter furnishes more subsistence to the human race than any other plant. Pursh mentions a grass which he calls the oryzopsis asperifolia, which he observed on the broad mountains of this country, and which, he says, contains large seeds, that produce the finest flonr. Perhaps this species of oryzopsis, although generically different, bears the same relation to z. aquatica, in its importance and place of growth, as the mountain rice of India does to the common rice of that region. At all events, the more I see of this country, the more I am convinced of its vast ability to support the human species, and of the propricty of calling its latent powers into operation. 


\section{LETTER XXV.}

Canandaigua, July, 1820.

MY DEAR Sir,

In passing by a spring a few days ago, I was called by some acquaintance to look at what they called a curiosity. It was the filaria, horse-hair worm, or gordius aquaticus-its color was dusky, , its length four or five inches, and its thickness about the size of a horse-hair. They represented it as a real horse-hair, transformed into an animal by being thrown into water, and although in other respects intelligent men, they no doubt conscientiously believed it. Providence has designed this little animal to perforate the most compact and tenacious clay, by which means the imprisoned waters of subterranean springs find a passage up for the use of man, and other organic beings. In consequence of this incident, I was about making some sage remarks on the low state of matural science in this country, when it occurred to me that the same doctrine of equivocal generation, or spontaneous production, was advocated from the time of the Stagyrite down to Priestley and Darwin. Harrey was the first philosopher. who had the temerity to enter the lists, in this 
case, against Aristotle. He advanced the proposition, omnia ex ovo, and the most profound and elaborate investigations of philosophy have confirmed his opinions. The polype furnishes indeed an argument against this doctrine. If divided into several parts, each part will become a perfect animal. I can only surmount this objection by supposing each polype, as it eppears in its usual shape, to be a congeries of animals, agglutinated together, and when a separation takes place that complete beings will existin a state capable. of enlargement. We see something analogous in the vegetable world. Trees produced from the cutting, without any sexual annexion. It is supposed that the weeping willow, or salix Babylonica, was introduced into Europe at the time of the Crusacies. It was transplanted from the river Euphrates about the year 1748, by Mr. Vernon, a Turkishmerchant, at his country seat in England. The English as well as the American weeping willow is a female, and exists in both countries in a widowed state. It is propagrated from the cutting, and so is the Lombardy poplar, which is only a male in America.

The introduction of pernicious insects ought to be carefully guarded against, and yet it is almost impracticable. Numbers of exotic insects are imported ia timber and packages of goods. 
The scarlet locust, figured by Edwards in inis Natural History, came accidentally alive from the West Indies in a basket of pine apples. A very curious instance was observed in England in 1S10, when an insect of the genus buprestis was taken from a desk made of fir, brought from the Baltic, and fixed up in 1788 or 1799. The cimex lectularius, or bed bug, was scarcely known in England until sixteen hundred seventy, when it is said to have been imported among timber used in rebuilding London, after the great fire of 1666 . 'The Amcricans assert the same thing in a more extended sense, and insist that fieas, moth, bedbugs and cock roaches, are foreigners. I do not believe that either allegation is correct. In 1670 there wcre not probably many bedsteads in England to attract the bug. Rushes and straw formed, at that period, the couches of most of the people. I know that pigeons often swarm with bed hugs, and also the domestic rabbit. I can speak from experience, when I say that the American bed bug is a larger variety than the English. How easy to avoid this evil by frequent ablutions-by bedsteads made of iron, or without any apertures -and by the use of a little sandal wood, which is an antidote against all kinds of insects, or in this case, of sassafras, which is said to be a complete preventive of the cimex lectularius, and 
precantions of this kind become absolutely necesary, when it is considered that this insect is constantly conveyed in the clothes and baggage of traveller's. The flea is certainly indigenous. It swarms in the most remote pine woods, and I have found it on squirrels. The cock-roach may, as Kalm supposes, have been imported from the West Indies : It has certainly found a congenial climate, because it increases greatly: Like all other winged insects, it travels rapidly. As to moths, I shall not undertake to pronounce on their origin; but I can furnish you with a complete antidote against their ravages. Red cedar wood will efiectually answer. Russia leather is tanned with this substance, and books bound with it set moths at defiance.

But I see you smile at my insect learning; and if you serve this letter as you have done some of its predecessors, and publish it, I shall probably incur the satire of the graciosos or bufioons of New-York. Aristophanes, in his attack, on Socrates, charged him with measuring the leap of a flea, and the most virulent accusation against Jefiersoss is the impalement of butterilies. What then do I care if I experience the fate of the most illustrious men of ancient and modern times. 


\section{IETTER XXVI.}

AY DeAR Sir,

$$
\text { July, } 1820
$$

The laws of Athens inflicted death on a foreigner who should attempt to speak in the assemblies of the people, and I think that such an unwarrantable interference with the sovereign authority deserved punishment. As a stranger and an alien, receiving the hospitalities and protection of this people, I do not consider myself authorised to meddle with their politics; but it is impossible to seal hermetically your ears against the noise and turbulence of political contention. Every village has its political generals, who convert the bar room of the inn into an arena of controversy, and sometimes, seated in a corner, I have been compelled to hear the accusations, the grievances and the vindications of the belligerent parties; and amidst the persiflage or jargon of the times, I can casily perceive that the whole controversy is about the offices of the country. After listening to a philippic of great virulence for some time, clothed in terms of general reprobation, I asked the orator to point out the reprehensible measures of the government. He approved of every thing 
but bad appointments. Good men, said he, (looking big) are not noticed-federalists aré appointed-republicans ought to have all the offices. I solicited hin to explain the difference between a republican and a federalist. Why, said he, a republican is a republican, and a federalist is a federalist. At this stage of the conversation, the orator was called out, and I understood that he had been, until lately, an ultra federalist-that at a celebration of Perry's victory on Lake Erie, during the late war, he had fired pop guns in ridicule of the event, and that he had abjured in a company of two score or so of high-minded men, his political name and creed, in order to attain office. The great clamour made in the community, appears to originate from such obsure and disreputable sources. Judging from the writings and conversation of this opposition, I should pronounce a great dearth of talent among them : and perhaps, if I may speak paradoxically, they owe some of their strength to their weakness. Their antagonists, in forming a just opmion of their want of intellectual power, appear to have underrated their capabilities for mischief, and unt to have guarded sufficiently agaiust their attacks. ford Clarendon has justly remarked, that "few men have done inore harm than those who have been thought to be able to do least; and tiere cannot be 
a greater error, than to belicve a man whom we see qualified with too mean parts to do good, to be therefore incapable of doing hurt. There is a supply of malice, of pride, of industry, and even of folly, in the weakest, when he sets upon it, that makes a strange progress in mischief."

The history of parties is a history of struggles for office and authority on the part of the leaders, who beguile the honest feelings of the penple into their traps of ambition, and the greater the clamour, the more inordinate the cupidity. It is common for a dog shut cut of a house in the evening, to bark and make a great noise, until somebody opens the door, and then instantly whip in and be quiet. 'This is a true delineation of the leaders of faction.

This state is making rapid and gigantic strides to eminence and greatness. Her canals are the admiration of the world, and her encouragement' of agriculture, literature, and the arts, is truly munificent. To see the profligate attempts to arrest this great system of public improvement, in order to elevate obscure petifoggers, and miserable drivellers, is really calculated to excite more than common sensibility. "Men, says an eminent writer, who honestly engage themselves in the public cause, must prepare themselves for 
events which will at once demand their patience and rouse their indignation."

I have frequently been struck with the stratagems adopted by drovers, to drive their cattle to market, by dividing them into separate lierds, to manage them completely. In like manner, the people are led by the divisions created by ambitious and unprincipled men, for the purposes of self-aggrandizement. Although these excitements have recoiled upon the agitators, and will unquestionably seal their political ruin, yet they are calculated to work great injury. The most diminutive insect may annoy the mightiest elephant, and the continual harrassments of politicasters may somctimes affect the plans of the wises statesmen. A combination of smatterers in literature, of sciolists in knowlege, of pretenders to public spirit, and of all that is little and contemptible, against all that is great and respectable can never prevail in an enlightened and patriotic country. 


\section{LETTER XXVII.}

$$
\text { July, } 1820 \text {. }
$$

Mr DeAr Sir,

The gradual changes which are constantly carrying on in this globe by the agency of fire, water, frost, and caloric, must in course of time derange its central gravity, and produce an orerwhelning revolution. The formation of stalactites and stalagnites, by the gradual accretion of calcerous matter, from water, filtrating through the more porous lime-stone. is well understoodand this accretion arises unquestionably from the passage of the water when saturated with lime from a heated to a cool atmosphere. The deposition of caicareous substances in the fissures of rocks from the water in which it was suspented, constitutes alabaster. And whenever water, impregnated with lime, comes in contact with cooler er water, it will deposit its calcareons matter, which will in course of time harden into stone. All the streams and rivers of the west, are filled with carbonate of lime, sulphate of lime, argillacenus schistus, and silicious stone, in a state of solution, but principally with the first, and when they enter into the lakes, rocks are gradually formed. The 
bottoms of Lake Erie and Ontario are principally lime-stone, which is in a state of augmentation. In the county of Onondaga, at a place called the Little Lakcs, I observed the great elaboratory of nature at work in the formation of calcareous rocks, and as I humbly conceive, by a double process. First, by depositions from its waters in which lime was diffused-and second, by the operation of springs rising from the botton of the lakes, and extruding calcareous matter from the howels of the earth. Whether I am correct as to this complex power, I cannot say-but as to the fact of the creation of tufa, it must be obvious to the most inesperienced eye. In orier to gain all the light I could on this interesting subject, I took a shortjourney to the village of Marcellus, in the connty of Onondaga. The pruduction of lime stones of large size at nine mile creck, near this place, is a very extraordinary thing. On the banks of the creek, there is a petritice un fosil tree, over which there is a large limestuns, and which stone must have been foruncd after the pintrifaction of the tree, aud the whole process is the rent to the observer. After the first deporiven and a consequent induration, the stone is anved by a lichen which retains a subsequent dow wirion, and which hardens and enlarges as before. The harduess of the lime stone increases with its depth 
and it finally reposes on schistus. The petrifac. tion of the tree is owing to the calcareous deposits. Saturated water continually passing over it, must leave some of its matter behind-and as the tres decays, its vegetable loss is supplied by mineral accretion-and sometimes the lime, in solution, is mixed with arenaceous particles which combine in the formation of the pretrifaction. I was told of three or four petrified white oaks at Chitteningo, which I had not an opportunity of observing, but they are said to lie under a grypsum hill, and to be subject to alluvions from it. I have seen the fossil tree at Penicuick in Scotland, which has been the subject of so much speculation, and I can now account for its origin. It was produced from Silicious depositions passing over a Scotch pine. The strata in which the remains of the tree are, consist of slate clay, but the tree itself is sand stone, and there is sand stone immediately above the slate clay.

I have tried the fossil trees of Marcellus by the application of muriatic acid, and I find by the effervescence unequivocal indication of a calcareous substance. I also saw petrified leaves, and there is a strong probability that animals may also be discovered in a petrified shape prod ied in the same way. The human skeleton whick 
was found inclosed in lime stone at Guadaloupe was no doubt a recent formation.

We thus see, my friend, the wonderful operations of nature. The Zoophytes of the South Sea are gradually encroaching upon the ocean by the erection of islands and reefs, and certainly by the agency of calcareous secretions. The lime stone rivers of the west are trespassing upon the lakes with a stronger and more commanding power.

This country is calcareous-its subsoil is formed of marle; it is the region of salubrity.

"There are more things in heaven and earth, Horatio, Than are dreamt of in your philosophy."

Depend upon it, my friend, that we are in $A, B$, $C$, of geology and mineralogy. We have proceeded to these studies like children at the first opening of their minds. We have learnt words and names only. These sciences are oppressed and barricadoed by a polyglot mysterious nomenclature. They require some mighty genius like Bacon or Newton to dissipate the Cimmerian darkness *hich hangs over them. 


\section{LETTER XVIII.}

\section{Salina, July, 1820.}

\section{My Dear Sir,}

I have returned to this place to look at the great manufactories of salt, which are conducted on a very extensive scale. The salt is not only better but cheaper that any in the United States; its superiority in these essential respects arises from the strength of the water, the cheapness of fuel, the facility of water conveyance, and improved skill in operation. It is supposed that five million bushels of salt are consumed annually in the United States, of which three millions are imported, and two made at home; and half a million is manufactured at this place.

The salt springs are situate in a marsh, and by digging a pit any where in it, salt water is found. The brine is forced up by hand pumps and hydraulic machines, and conveyed by leaders to the caldrons. One man can attend a block of ten kettles. The process of manufacturing is simple. 'The water is exposed to a hot fire, and when it is sufficiently boiled down, the salt is taken out by a large ladle, and put into a basket, from whence the water exudes into the liettle. 
The ladle is kept during the whole process in the caldron, and it is said collects all the feculent matter.

The salt is of three kinds ; common, rectified, and basket, or table : and salt is made at Montezuma by solar evaporation. Fifty-six gallons of water make a bushel of salt. It is said that it takes 100 gallons at the Great Kanhawa river, and 300 at the Conemaugh works, near Pittsburgh. Wood can be procured at 02 cents a cord, and two cords will supply a block of caldrons for a day.

The common salt is very excellent-the rectified extraordinary so. The best kind of the latter is put up in baskets of $3 \mathrm{lbs}$., which cost each twelve and and a half cents.

It is supposed that the salt springs originate from subterranean rivers running over mines or beds of fossil salt, and as Salina is elevated 100 feet above the Oswego fulls, which are composed of sand stone, that the mineral can be found at that depth. Many phenomena all over this country demonstrate the former presence of the ocean and it is supposed that a line of country consideraibly above the Cayuga murshes, and the Salina 1)lains has been a sea shore. On the recession of the ocean, hose great hollows must have retained rast quantities of salt water, which would be con- 
verted into salt by solar evaporation, or subterranean heat. But it is evident that this theory is not commensurate with all the facts in the case. Salt springs are found as far east as forty miles, and all over this western region.

In 1806 and 1819, years of great drought, the water was very weak. On what principles can we account for this extraordinary fact? There never has beeu the least failure of water.

I saw on the salt marsh, the samphire of the sea coast. Tournefort made the same observations in his voyage to the Levant. "There are, said he, some small risings of fossil salt in Georgia. 'This salt, which chrystalized in bottoms where the rain water stagnates, mixes with the moisture of the earth, and causes it to produce such plants as love the sea shore-such as saltwert and limonium, I observed the same thing upon the mountain of Cardonna, situated on the frontiers of Catalonia and Arragon, which is nothing but a prodigious mass of salt."

The country about the salt works is said to be unhealthy. The same evil has been noticed in other places. The spots in Greece, where the malaria is most noxious, are salt works and rice grounds.

I have no doubt but salt can be procured at Salina for 18 cents a bushel: including the duty 
of $12 \frac{1}{2}$ cents. It can be transported to Albany for 6 or 7 cents more when the canal is finished. The duty on imported salt is 20 cents per bushel. The average price of salt at New-York, is from 40 to 50 cents per bushel. Whether the foreign duty is continued or not, the salt of Salina can always be sold cheaper at the head of the sloop navigation of the Hudson, than foreign salt. Every individual in the United States consumes at the rate of half a bushel of salt, directly or indirectly. Supposing the consumption in the aggregate to be five millions of bushels, and the population ten millions, then that portion of the inliabitants which is comprehended in the supply from Salina, will not have to pay more than from $12 \frac{1}{2}$ to 25 cents for the annual consumption of that article.

I consider the salt manufacture of Salina the most important establishment in the United States. It renders the nation so far independent of foreign aid : millions of bushels can be made. Without the canals it usefulness would be very circumscribed-but now the facilities of inland navigation enable the conveyance of this indispensible mineral to the remotest regions of the west, and to the shores of the Atlantic ocean. 


\section{LETTER XXIX.}

$$
\text { Montezuina, July, 15:0. }
$$

Mr Dear Sir,

I consider navigation on a canal, not only the least expensive, but the most secure mode of travelling that can be adopted. Here is no bursting of boilers nor any other accident to which steam-boats are exposed. You can neither be burnt nor drowned, and your horses cannot run away with your carriage and dash it to atoms; but then you must be on the constant look out to aroid a fracture of the head from the low and ill constructed bridges: why, in this country of wood, stone should be used for erecting bridges; why they should be made so low as just to avoid the boat; why they should contain abutments jutting out into the canal, and for ever striking the boat; and why the stones should be piled upon each other without mortar, are questions which I must refer to the decision of the Canal Board and their engineers. If the bridges had been sufficiently elevated, then the boat could bave been drawn from a mast instead of the side, as is practiced in Flanders, and an unccasing ard pernicious wearing of the banks by the drag rope 
would have been prevented. I know of no other accidents that can happen, except fiom the falling of trees across the boat, or from the carelessness of the men who have the management of the locks.

I saw at Jordan, which is 80 miles from Utica, two loaded boats, which had left Schenectady seven days before. This would average 25 miles a day, and part of the way is on a difficult ascending navigation up the Mobawk. Again; a vessel of 50 tous went from Utica to Trumansburgh on the Cayuga Lake, 130 miles in three days, loaded with merchandize, and without a change of horses. A loaded boat can go on this canal without difficulty at the rate of 40 miles a day.

I have just learnt that the state is about purchasing the rights of the Western Inland Lock Navigation Company. This is a very just and proper measure. The works of the Company are out of order, and the toll is exorbitant. Every bushel of wheat has to pay a duty of 59 cents before it reaches Schenectady.

The canal of this Company at Rome is one mile and three quarters long, thirty-two feet wide at top, and from two and a half to three feet deep. It has two locks 73 feet long, and 12 feet wide. The lift of the one on the Mohawk is ten feet, and on Wood Creek eight. This work was made 
under the direction of Mir. Weston, an Englisix engineer, who had, besides his expenses, a salary of a thousand guineas a year. The superintendant of the laborers had a salary of 2,500 dollars; and this short canal took two years to make. What a difference in management: procceding at the same rate, it would take two centuries to complete the Great Canal. The water cernent was imporied. The lock at the German Flats was made of terras, and at the Little Falls of Welsh lime. The former has answered best.

The tolls of this Company are so oppressive, that boats frequently unload and pass through the locks empty, and resume their load afterwards. It is indeed well that the state has purchased it. I am persuaded that the markets of New-York will now be supplied with western, instead of southern flour, and that the displacement of the latter from the market will greatly affect the agriculture of the south.

In looking at the great results which must arise from it-it is impossible to keep out of view some of the revolutions which will take place in the internal trade of the country. There is a certain class scattered all over, who unite in one profession, the calling of iron mongers, grocers, druggists, and shop Keepers, and who are continually offering temptations to purchasers. The facility 
of conveyauce by the canal, will induce people to resort to villages for supplies. 'The thrifty housewife will take her cheese and her butter to market, and return with her sugar and tea. A numerous non-productive cailing will be in some measure broken up, or confined to towns.

A considerable deal of trade will be carried on sy exchange, and more scope and greater encouragement will be afforded for the operations of industry and economy. A vast capital will be employed to more advantage. A cana! boat of 40 tons can be purchased for 400 dollars, which, with two horses, will be cheaper than a heavy magon and six horses, and will convey ten times as much. The comparative cheapness of canal barges to river sloops as well as wagons, will supersede the necessity of very large investments of capital.

With all these and other important advantages staring the community in the face, is it not extraordinary, that there should be an organized opposition against the canal! that wretches should be encouraged to instil poison into the public mind against it, and to destroy its embankments? By the bye, can you tell me why accidents in the bursting of embankments and mill-dams occur more fiequently in the night time than in the day? 
Are they owing to a greater pressure of the atmosphere on the water?

\section{LETTER XXX.}

$$
\text { Auburn, July, } 1820 .
$$

My Dear Sir,

I An so anxious for the discovery of coal, in order to promote the prosperity of this growing country, that I can hardly turn my eyes or my mind to any other subject: Sure 1 am that it exists. I have seen indications in various places, but in truth you cannot get people to make the requisite search. It will consume time and money. They have plenty of wood, and they conceive any other fuel as a remote, if an attainable good. Coal was first introduced into London about the midale of the thirteenth century, and it goes by the various names of pit coal, stone coal, pitch coal, and sea coal. The citizens of London, in the 35th year of Edward I. petitioned that the use of it might be prohibited, considering it a noxious material. If this petition had been granted, where would have been the wealth and power of England? If the citizens of this state do not evince open hostility, they certainly show a narsotic indifierence on this interesting subject. 
Being so fully inpressed with the importance, and practicability of obtaining coal, permit me to throw out a few hints, which may furnish materiaks, not only for obscrvation, but for action.

Birch, in his History of the Royal Society, observes, that the mines in Devonshire and Cornwall run east and west; and this is said to be the case with coal and other minerals, except lead, which has not been observed to have any current or declivity of the vein, but is most commonly found north and south by the miners. Most mines lie high in the west and so deepen more and more the further east they run. So far as coal has been discovered in the western states, I am told it runs east and west, and in the sane direction with gypsum, salt, lime, and sand stone; and if it be true that it descends and deepens to the east, we may easily see why more has been discovered as you proceed to the west.

I believe that I omitted to mention that whinstone, or basaltes, whose hardness is such that its angular froctures will scratch glass, is found in most coal mines. As basalt is a secontary rock, I have no doubt but that it exists in many parts of this regrion, although I have only seen it at the Linte Falls, which has to me much the aspect of a cual country. Shistic and saud stores 
are with lime the prevalent rocks, and they are invariably the associates of the Coal formation.

Sir Robert Atkins, in his History of Gloncestershire, obscries, that if you lay a line on the terrestrial globe from the mouth of the Severu to Newcastle, and so pass round the globe, coal is to be found within a degree of that line, and scarce any where else in the world. I have not the means of applying this remark to this country, but if you think it worth while to notice an observation so eccentric and fanciful, your globe will soon enable you to do it.

Whether coal is a chemical deposit, or vegetable formation, I am not prepared to say, but in any conceivable theory, I am persuaded that the strongest reasons exist to show that it may be found in this country.

\section{ETTER XXXI.}

Montezuma, July, 1820.

Mit Dear Sir,

WHEx I travelled in the steam boat from NewYork to Albany, I had an interesting conversation with an intelligent merchant from a neighboring village, who told me that goods which cost 40 dollars to transport by water from New-York 
to his village, a distance of 150 miles, would cost 450 to convey by land to Whitehall, a distance of of 70 miles. This great deduction must render the goods proportionally cheap.

The truth is, that as a canal extends in lengtin, it embraces in a kind of geometrical ratio, a greater or wider extent of country, and difuses correspondent blessings. Every man residing within a day's journey of the canal, is for all useful purposes brought to that distance from Albamy, with the exception of the price of transportation from the point of the canal which he touches to that city, and the time consumed in the conveyance.

When this work was first proposed to President Jefferson, in 1809, he pronounced it impracticable as the present time, and declared that it was a century too soon to make the atternpt. Why this great misjudgment occurred to this great man, and to many other wise men, must be imputed to their overlooking important facilities, and to their indiscriminate application of past events to present times, without takingr into consideration important dissimilarities. A canal can be made with infinitely more facility in a region of seconcary formation, than in one of primary. Granite, sernite, gneis, and mica slate, do not exist cxcept furtuitously, and the prevailing rocks present 
no formidable obstacles to excavation. It is in fact little more than a turnpilie reversed, a work in concarity instead of convexity. The application of ingenious contrivances for the extrication of trees, and the processes of excavation, has never been duly appreciated until submitted to the test of experiment. Nor was it anticipated that work could be carried on to great advantage in winter as vell as summer. Besides the whole mystery of the expense and the failure of great public works, is the frauds aud mismangement of the agents. A judicious system conducted with integrity and industry places it in the power of an opulent state to accomplish any undertaking.

In my opinion, this state will not only obtain incemrification, but will eventually derive a great revenue from the canal. In the hands of an able financier, a kind of impost, under the form of tolls, will be laid on ascending goods, which will either produce an important revenue, or check rhe wasteful consumption of foreign merchandize; thus encouraging in the one case domestic manufactures, and in the other enriching the treasury. This will be the exercise of a new power by the local governments. If the national government will not raise the tariff for the benefit of its own manufactures, the state government can elevate it suficiently by tolls. 
1 am happy to assure you, that the supply of water is ample, although I am persuaded that the leakage and evaporation are more than was anticipated. Distant cellars have been filled, and in some places the quick sands present a formidable appearance, but the progress of time will avert many evils now experienced. The holes and fissures in the canal will be filled up, and the banks will become more solid.

There are many contrivances in contemplation for the propulsion of boats. An ingenious mechanician in New-York, has I see prepared an hydraulic machine. Steam may be used successful$1 y$, but I am of opinion that horse power will be generally adopted.

The advantages which will be constantly developed by this great work, will undoubtedly be shaded by some inconveniences; but these will be lost and extinguished in the immensity of good. And every citizen of this powerful state may exclaim in relation to the greatest work of the age,

$$
\begin{aligned}
& \text { "And thon shalt be our star of Arcally, } \\
& \text { Or Tyrian Cynosure," }
\end{aligned}
$$

to all that can render a people opulent and powerful, capable of dispensing and receiving blessings. 


\section{LETTER XXXI.}

$$
\text { Utica, August 1, 1820. }
$$

Mr Dear Sir,

ONE of the modern poets has elegantly said.

$$
\text { "-One small spot }
$$

Where my tired mind may rest and calt it Home:

There is a magic in that little word:

It is a mystic circle that surrounds

Comforts and virtues never knowu beyond

The haliowed limit."

The same feelings which attract us to home. when absent, enhance the importance of our native country when in foreign climes. Every thing which relates to Ireland has now a double charm and a double interest in my estimation. I can stop and converse by the hour with the humblest laborer from my native land, and do not postpone my attentions to inquire whether he is a Catholic or a Protestant, a Royalist or an Oppositionist. Even a panegyric on Castlereagh now sounds melodiously in my ears.

- With all these predilections I cannot shut my eyes against the false taste which has pervaded the Irish oratory, and which has extended to this country. Grattan, Curran, and Phillips, are cona 
sidered the master spirits of modern elogrieire The works of the two latter are to be fou: $3 \quad \cdots$ every bookstore and every library: the $y$ a e read and admired, and admired and read by all reading men, women, and chiluren, in America. Phillips-the orator of fustian and bombast has run through several editions.

The really great orator of Ireland was $\mathbb{E}$ dmund Burke, a man of a rich mind, adorned with a luxuriant inagination-stored with various and profound knowledge-and embellished by a correct and classical taste. His speeches at the commencement of the American revolution are models of genuine eloquence, and exemplars of political wisdom.

After him came Grattan-the orator of epigram and antithesis. His eloquence was formed under the ascendancy of false taste. We admirc the poignancy of his satire, the veliemence of his denunciations, the intrepidity of his demeanor, and the felicity of his language-but we soon become fatigued with his elaborate attempts, his involved sentences, and his quaint ideas. We turn aside from his condiments, and require substantial food for the mind. In attempting to condense like 'Tacitus, he has fallen into the conceits of Seneca.

Next came Curran, a man of lofty intellect. but laboring still under the same fatal ascendan. 
cy. He attempted to soar into the empyreat heights of oratory, but how often does he mistake bombast for sublimity-quaintness for energyand the erratic nights of an undisciplined imagination, for the most elevated effusions of the human mind.

Last comes Phillips-Phillips the Orator as he is called. O how I blush for my country-that such a trainless biped should be followed with acclamations, and covered with honors-Phillips, the prince of Dandy orators-whose "gaudy, gauzy, gossamery eloquence," full of glitter, bombast, froth, and fustian, is nauseating to good taste, and a disgusting exhibition of flowery nonsense. He is in eloquence what Hervey was in fine writing-continually on stilts-continually straining after figures-pursuing conceits-and clothing puerile ideas in an embroidered phraseology. His oratory is without essence or substance; it either sinks into dregs, or rises into lees. He is, among real orators, what a peacock is among birck-a beau among men. I do not however, mean to deny him a fertile imagination, but it evaporates in frothy verbiage, and he comes directly within the censure of Quinctilian-"Sunt, qui neglecto rerum pondere et viribus sententiarum, si vel inania verba in hos modos depravaatnt, summos se judicant artifices; ideoque non 
desumunt eas nectere: quas sine sententia sectare ${ }_{3}$ tam est ridiculum quam quærere habitum gestum. que sine corpore__ Ubi vero, atrocitate, invidia, miseratione pugnandum est; quis ferat verbis contrapositis et consimilibus, et pariter cadentibus, irascentem, flentem, rogantem?"

If my national partialities are neither flattered nor increased by this rapid review, they certainly have great scope for exultation, when I turn my eyes to my countryman Thomas Addis Emmet, who now ranks among the first advocates of the American Bar, and if in Ireland, would distance all competition. I have heard him, and heard him with perfect astonishment. He has an allgrasping mind, which can penetrate the most abstruse, irradiate the most obscure, and comprehend the most intricate and perplexed subjects. For compass of thought, for soliclity of reasoning, for acuteness of investigation, for feicity of illustration, for energy of expression-he is without a rival. In private life, he is one of the most amiable and unobtrusive of men-"In wit a man-simplicity a child."

There is a great excitement in this country against the British Reviews for their strictures on the state of American learning, and yet these vitupcrative Reviews are to be found in every reading house in this country. Jeflery is looked up to 
silh idolatry, and the Quarterly Revicw is quotcd on an oracle. Blackwoood's Magazine is in ingh request-the novels attributed to Walter Scott, rev swed for a barbarous dialect, and a dull momotony, are notwithstanding classed with the prouluctions of Fielding and Richardson, and all the modern poets, including Byron, Scott, Nioore, Southey, Wordsworth, Coleridge, Crabbe, sce. are printed and reprinted, lauded and admireu from Maine to Missouri.

If America will not stand on its own legs, and rely on its own exertions, what can it expect but supercilious arrogance and contumelious assumption? Is there any thing so wonderiul and so terrific in Scotch criticism-in the pen or the sneers of little Jefiery-or of Southey, or of Scotch barristers who set up for Quinctilians, or of English poetasters, who claim the highest honors of genius?

There is an American writer named Irving an amiable man, of a fine pellucid mind, and who has distinguished himself by some amusing periodical works. He is greatly superior to any writer in Blackwood's Magazine, and yet the suffrage of that Magazine in his favor, is quoted as the highest reward which can be conferred upon him.

Why the American people will not bestow more encouragement on a vernacular literature, instead 
of ruming after exotic ges - gु?ws, I cannot divine. The North American Review is now covelucted with inne taleat than eicher the Q arterly or Ediuburgh. D:. Sillinan's periodical wor! on Natural Science is superior to any thing of the kind published in Europe; and there are men of genius and of learning in every section of the country, who with adequate encouragement would redeem the American character from the obloquy of transatlantic insolence.

\section{LETTER XXXIII.}

\section{Western Region, August, 1820.}

Mr Dear Sir,

THE beauties of an American sky are frequently unparalleled, and there is a peculiar lustre in the appearance of the morning star, which I have never seen equalled in my native land. This planet, on account of its propinquity to the earth, is only exceeded in apparent size by the moon, and on this account, and its superior effulgence, it has very naturally been a subject of poetical description. It may relieve the monotony of my former communications to refer to some passages in the most distinguished poets on this subject. 
Ilomer in his fifth Iliad, in representing Diomede under the influence of Pallas, says,

Fires on his helmet, and his shield around

She kindled lright and steady as the star

Aitumnal, which in occan newly bath'd

Assumes fresh beauty.

The same allusion also occurs in Horace-

Merses profundo, pulchrior eve nit.

Firgil in his 8th Eneid, says-

Qualis ubi oceani perfu us Lucifer unda,

Queın Venus ante alios astrorum diligit ignes.

Extulit os sacrum cælo tenebrasque resolvit.

Lastly comes Milton, who thus exclaims in his Lycidas :-

So sinks the day star in the ocean bed, And yet anon repairs his drooping head, And tricks his beams, and with new-spangled ore Flames in the forehead of the morning sky.

If these extracts shall be considered as fair specimens by which to compare poetic merit, in what an illustrious light does Milton appear?

A poet as well as an orator, in order to be truly great, ought to have a fertile imagination, under the dominion of good taste. Those faults which result from undisciplined genius, are however more tolerable than those which spring from steri- 
lity of mind. In one of my solitary walks, I stopped at a farm house for refreshment, and I accidentally found an old newspaper which contained an address, from a cidevant governor to a great military commander, on the presentation of a sword. The writer has evidently put his mind into a state of violent exertion, and in striving to be sublime and magnificent, has shown a total in. capacity in thought as well as language. In speaking of a nocturnal battle near the cataract of Niagara, he says that it produced a midnight rainbow, whose refulgence outshone the iris of the day.

This master-piece of the great orator and statesman who wrote it, can only be excelled by the poet quoted by Dryden, when he says-

Now when the wiuter's keener breath began To chrystalize the Baltic ocean,

To glaze the Lakes, to bridle up the floods, And perivig with suow the bald pate woods.

Or perhaps it is exceeded by the following eulogium of a country school-master on General Wolie.

Great General Wolfe without any fears,

Jed on his braye grenaliers,

And what is most miraculous and particular,

He climb'd up rocks that were perfendicubir. 
And yet would you believe that the man who pronounced that farrago of bombastic nonsense, has been a governor, a vice-president, and Ciod knows what; and that he is passed of as a parag'n of wistom, and an exemplar of greatness. With intellect not more than sufficient to preside over the shop-board of a tailor, or to conduct the destinies of a village school, he has by the force of fortuitous circumstances attained to ephemeral consequence. D'Alembert has justly observed that "the apices of the loftiest pyramids in church and state are only attained by eagles or reptiles." The history of democracies continually exhibits the rise of pernicious demagogues warring against wisdom and virtue, philosophy and patriotismbat winy do I confine this remark to any particular form of government? 'The spirit of the obserd vation will appiy to human nature in all its forms and varieties. Even in the Augustan age of Great Britain, Elkanah Settle was set up as the rival of Diyden-and Stephen Duck was put it competition with Pope. This levelling principle gratifies two unworthy feelings; it endeavors to mortify the truly great by its flagrant injustice, and it strives to lower them down to our own depression of insignificance. Posterity, however, wili dicpense justir e with unerring hand, and with impartial distiibution, and the great men who are 
almost always assailed by calumny, and who are sometimes borne down by ingratitude, may in considering the benefits which they have rendered to the human race, confidently appeal to heaven for their reward, and to postcrity for thcir justification.

\section{LETTER XXXIV.}

Westorn Region, August, 1820.

My Dear Sir,

Althougr my luggage is small, yet I never travel without a blow-pipe, and some tests and reagents. If in want of any of the usual acids to detect the presence of lime, I substitute strong vinegar, which will gencrally produce an efiervescence, when poured on a calcareous substance. If I am desirous of ascertaining the existence of an alkali, or an acid, I stain paper with the petals of a blue flower, and dip it in the water which is to be tried, and if it tura green, it indicates an alkaline impregnation, and if red an acid one. If silver becomes black when thiurn into water, it denoies that sulphur is beid in solution, o the the presence of iron is dencustraterl, if ine intre trakk of oak give water a dark apjearance. With 
these occasional substitutes I am enabled to surmount to a certain extent, the want of a chemical apparatus, when I travel at a considerable distance from my lodgings. With my slender materia!s for investigation, I have, however, been been crabled to ascertain the great geological outlines of this region. The country about eight miles south of the Cayuga Bridge, and both east and west, is composed of argillaceous schist, or clay slate. To the north, the great lime stone ledge commences, which dips to the south, and which forms the dam of the Cayuga and the other minor lakes, and which upholds Lake Erie. This ryreat calcareous ledge is interspersed with all the species and varieties of that substance, and with salt, sulphur, carburetted hydrogren, and bituminous springs-with gypsum, hydraulic lime stone, magnesian lime stone, fetid carbonate of lime, blue lime, shell lime, silicious lime, with nodules of flint, \&sc. in stratified and scattered portions. And the substratum of the calcareous and schistous formations, is, as far as 1 can trace it, a compact sand stone, generally of a red color.

I found the upper and middle stratum of the great cataract of Niagara to consist of fetid carbonate of lime, commonly called stink stone, or swine stone; and the inferior stratum of a compact, stratified red sand stone, which strikes fire 
with steel, scratches glass, and which, when moistened and rubbed, enits a smell of sulphuretted hydrogen gas. It is also infusible before the blow pipu, and does not efiervesse with acids. The super struta, conssting of sivine stone, are more strongly impreguated with sulphuretied hydrogen gas, and contaiu small quantities of martial pyrites, alunine and silica. This stone exists in various parts of this region, and is an indication of coal, so far forth as bitumen is concerned in its composition.

The great coal beds of Ireland repose on lime stone, which is also intermingled with the coal mines of the region further west of this state; and I have been told that at a place near Zanesville, in the state of Ohio, a cellar was dug and walled, which furnished for its construction, sand stone for the wall, lime stone and sand for mortar, and a suficiency of coal for calcinating the lime. Clay slate generally forms the roof of coal mines, and sand stone the floor. These different formations sometimes intermix with, and sometimes underlay each other in this region, and they all point with an unerring hand to the existence of this all important substance of coal.

The black shale which contains bitumen-the oil stones-the petroleum springs-all concur in corroborating this conclusion. Below the celc- 
brated petroleum wells, in the Burmha' dominions, coal has been discovered. Indeed, it is supposed that the oil from these springs possesses all the properties of coal tar, and that nature elaborates for the Burmhas in the bowels of the earth that for which Luropean nations are indebted to the ingenuity of Lord Dundonald. A considerable spring of petroleum exisis at Colebrook Dale, in England. At some distance below, coal is found of an excellewt quality. Cleveland, in his celebrated wort on IHincralogy, supposes that naptha and petroleum mey very probably arise fiom the decomposition of coal, effected by subterraneous fires, either volcanir, of prodaced by the combustion o col, or the decomposition of pyrites.

I have perhaps fatigued you with my lucubrations on coal. When 1 consider the importance of this miseral-its auspicious influence on the production of the great fabrics of art, and on the comfort and support of the hunian race; and when I am convinced that notling but observation and exertion are necessary to effect the discovery of this precious mineral, I cannot think my time misspent in drawing your attention to it. The state ought to offer a magnificent reward for the discovery. 


\section{LETTER XXXY.}

\section{Western Kegiun, August, 1820.}

My Dear Sir,

I FIND that my letters have unexpectedly atiracted so much attention, that $I$ consider it $\mathrm{ex}$ pedient not oniy to change the place of my residence, but to conceal it under some general de. 3omination. In passing along the main street of Canandaigua I overheard some boys say-there roes Hibernicus, and I assure you that my diffidence took the alarm, and I soon resumed my erratic life. I am now one of the nomades, without any fixed habitation, wandering from place to place, and collecting new ideas and feelirigs wherever they are to be found.

In the district of country called Rome, a species of wheat, or triticum, was shown to me as indigenous. The novelty of the idea pleased me 9o much, that I pursued the discovery through all its labyrinths and ramifrations.

Some years ago, it was discovered in a wet soil and in a beavel meadow, near $W$ estern, and also in a swamp covered with woods, near Rome. Its stalk is more compact, and its leaves larger, t'ran that of the common wheat, Its lacight is also 
greater, and except having short beards at the apex, it is in other respects bald. It is said to resist the power of frost, and to be proof against winter killing.

Is this wheat indigenous, or was it imported and accidentally conveyed to the places where it is found?

If the latter, why is not wheat found growing wild in more cultivated parts of the country? I am persiaded that it is an indigenous plant; and if su, it may be considered one of the greatest discoveries of the agre. It is the vegetable destined by nature for this climate, and it casts light upon the natural history of the most important of the cerealia which has hitherto been enveloped in obscurity.

Wheat grows in the old world from Egypt to Siberia, upwards of 30 degrees of latitude. Pennant says that wheat will ripen as high as latitude 62 north, but so uncertain is the crop throughout Sweden, that it is called the seed of repentance. A species of wheat which is called Siberian, and which has been found growing wild in that country, ripens in a latitude still more north than that laid down by Pennant. Kaimes observes, that"Writers upon Natural History have been solicitous to discover the original climate of wheat, rice, barley, \&ic. (which must, from the creation, have 
grown spontaneousiy) but without much success. The original climate of plants left to nature cannot be a secret, but in countries well peopied, the plants mentioned are not left to nature - the seeds are carefully gathered and stored up for food. As this practice could not fail to makc these seeds rare, agricuiture was early thought of, which by introducing plants into new soils and new climates, has rendered the original climate obscure. If we can trace that climate it must be in regions destitute of inhaüitants, or but thinly peopled. Anson found in the island Juan Fernandez many spots of ground covered with oats. While the French possessed Fort. Dauphin, in the island of Madarascar, they raised excellent wheat. That station was deserted many years ago, and wheat to this day grows naturally among the grass in great vigor. In the country about Mount Tabor, in Palestine, barley and nats grow spontaneously. In the kingdom of Siam, there are many spots where rice grovs yar after year without any culture. Dindorus Siculus is our auth rity for saying, that in the territory of Leontinum and in other places of Sicily, wheat grew wild without any culture. And it does so at present about Mount Etua." Diodorus Siculus also says that Isis was the discoverer of wheat and barley, and that Osiris taught the manner of cultivation. 
And according to Berosus, Mesopotania abous. ded with wild wheat amongst the other indigenous plants.

Tibullus says of Osiris-

Primus aratra maru sulerti fecit Osiris

Lit teneram ferio sollicitavit humum.

And Ovid thus spealis of Ceres:

Prima Ceres unco terram dinovit aratro Prima dedit leges,

Why should not wheat grow spontaneously in New-Iork as well as in Sicily, Egypt, Mesopotamia, or Sibcria? And the evidence of the fact is as complete in this particular as the nature of the case will admit. The plant was found in a wild state in places remote from thick settlement, which had never been cultivated, and it possesses peculiar characteristics, and distinctive qualities. 3csides rye is found in a wild state, and it was frequently seen growing spontaneously before the settlement of the country. Lt. Governor Mercer, of Virginia, thus writes of this plant, a long time before the revolutionary war:- "The wild rye which grows every where in the Ohio conntry, is a species of the rye which is cultivated by the Europeans. It has the same bearded ear, and produces a farinaceous grain. The ear and grain in 
the wild state of this plant are less, and the beard of the ear is longer, than those of the cultivated sye, which makes this wild plant resemble more the rye grass in its appearance; but it differs in no other respect from the rye, and it shoots its spontaneous vegetation about the middle of November, as the cultivated rye doth."

As the indigenous existence of rye in this counryy is established beyond question, there can be 110 good reason to doubt the growth of wheat. This curious fact in Natural History, ought to be fully investigated and illustrated.

\section{LETTER XXXV1.}

Western Region, August, 1820.

My deAr Sir,

WheN I consider that without coal there can bc no stable manufactures-that without manufactures there can be no flourishing internal tradeand that without internal trade, there can be no elevation of national prosperity-I trust, nay, I am sure that you will excuse me for drawing your attention once more to this important subject. 
The rocks of the west are sand stone,

$$
\begin{aligned}
& \text { slate, } \\
& \text { lime, } \\
& \text { Eypsum, and } \\
& \text { salt, }
\end{aligned}
$$

and they are all the companions of coal. But I shall waive theoretical considerations, and shall now point out such places where I am persuaded coal may be found.

The ravines or glens of the country formed by streams are the best places for gcological observations, and for viewing the indications of coal, and other minerals. The country from Ithaca north is a region of argillaceous schist. Near the former place there is a beautiful cascade tumbling down the eastern hills 60 feet high through a Cimmerian glen over clay slate, which alternates with a thin stratum of lime stone that reposes on a similar schist. There is a profound gulf at this cascade, and the tout ensemble points to the existence of coal. 'This place would be a good venue for a romance.

At Ludlowville, 10 miles from Ithaca, the banks of Salmon Creek are 200 feet high, and very precipitous. The rocks are principally clay slate, and there are strata of blue lime stone half way up. 


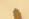

Further north, the whole of the town of Scipio is underlaid with clay slate, which is invariably found in digging for wells at the depth of 15 or 20 feet. This substance forms the roof of coal mines.

The formation of the Onondaga country is very singular. High hills-profound vallies like the arms of lakes. Onondaga Hollow is a beautiful valley surrounded by elevated hills which afford a most picturesque view. At the foot of these hills, and in the glens created by the streams passing into the valley, search may be successfully made for coal, and it may sometimes appear in out-bursts.

There is a blackish shale at Jamesville, west of Hanlius square, and on the bills east of the latter place, and between it and Chitteningo there are strong indices of coal, and particularly on a hill between Cazenovia and Manlius, where there is much shivery slate.

The whole of this interesting region is full of gypsum, and wherever there is gypsum, there are salt and coal. In Manlius, gypsum is always tound at least at the depth of 15 feet. In diggring a well 72 feet, gypsum was discovered 15 feet from the surface, 46 feet in thicliness.

The shores of lakes and the falls of treams, frequently extribit the evidences of coal brombit 
and collected by the agency of water. I have seen on the bank of the Owasco and Otisco lakes, black shale, which is found rounded and abraded by the waves.

At Little Fall Creek, a mile south of the village of Genesco, there is a vertical section of 115 feet through rocks. The siper stratum is slate, reposing on limestone, which is again supported by schist. Here are evident symptoms of coal, and here it may be certainly obtained.

The black mould on the Genesee river is derived in all probability from the trituration, or decomposition of slate, impregnated by bitumen, although some give it a vegetable origin.

At Allen's Creek, in Le Roy, there is a vertical section. The upper stratum is clay slate, which the water has worn away to the lime stone, and which reposes on bituminuus slate that smells exactly like Seneca Oil. The same slate is found at Batavia in detached pieces, brought by the Tonawanta Creek from a distance. The country west of the Genesee river is composed of three terraces, like tlue Steppes of Tartary, which incline gently to the noth. At the feet of these terraces, search ought to be made.

I think, my dear sir, that I have indicated a sufficient number of places, where

" "Sable coal his ruassy couch extendș.." 
When the usual indices of this mineral appear. the augur ought to be applied; and I earnsstly recommend voluntary associations of opulest and observing men, for the discovery of coal. A fruitful mine within 30 miles of the Great Cana will be the nucleus of immonse wealth.

\section{LETTER XXXVII.}

\section{Western Region, August, 1820.}

Mr Dear Sir,

The Systema Naturæ of Linnæus has bee eloquently described as "the Bible of Nature, the great nomenclature of natural science; where every generic character is a family portraiture, and every specific description a miniature; and where, by a few simple appropriate terms, the image of every distinct object on the globe we inhabit is reilected on the mind and the memory;" and Dr. Johnson has justly observed that "the stream of time, which is continually washing away the dissoluble falorics of other systems, passes without injury by the adamant of Linué." The object of Linnæus was to simplify natural science by systematic arrangement, methodical classification, and comprehensive description. Iis classes, orders, genera, species, and varietics, 
were admiribly adapted for this purpose. 'Tir. two first are arbitrary, and the three last founded on nature. This system, when it came out of the hands of its great architect was recommended by its simplicity, and by its tendency to facilitate the acquisition of knowledge. In the progress of time it has become corrupted by the interpolations and sophistications of inferior workmen, who have destrnyed its beauty, deranged its symmetry, and undermined its strength. The multiplication of terms, the atignentation of synonymes, the creation of new genera, and the fabricaion of new species, have overloaded the science. with an Egyptian burden of terminology. Philosophy has been transfurred from things to words, and the inventor of a new term, or of a specific or generic diference where none exists, has been a'surdly considered as entitled to the honors of an important discovery. A new race of naturalists have started up, who confine their attention -olely to rerbal description, and who entirely overlook the habitudes and manners of animals, and the nses and characters of other organic leings, and of inorganic matter. The splitting up of genera, and the subdivision of species occipy their exclusive attention; and if they can find a new name for an old thing, or feign imaginary differences, then they fency themselses great phi- 
iosophers, and figure away as men of original ge. nius. This preposterous conversion of varieties into species, and of species into genera, has produced infinite injury to the progress of real knowledge, and has barricaded the approach to the temple of science by a fortification of hard words. Sciolists of this description hold the same rank in natural science, that special pleaders do in law, and scholastics in philosophy. I have discovered a new genus in botany, exclains one of these pretenders. What, a new plant! no, but that a plant well known and often described as of the some generic character, can be distinguished, in its different appearances, by certain discrepances, which authorise a new discrimination of nomenclature. The truth is, that all these great discoveries are nominal, notreal; and are founded on fortuitous, not natural circumstances. I have seen a white deer-a white moose-and a white squirrel. Would it not be entirely ridiculous to arrange these accidental varieties into new species? The natural color of the jackail is yellow :-Suppose that the prairie wolf resembles that animal in all other respects, would we hesitate to pronounce it a jackall? Look at the mineralogical synonymes of Allan, and you will see the infinite dificulties which a student of mineralogy has to encomnter. Let us take a 
word well known to every one, gypsum, for instance, and besides its appropriate name, sulphate of lime, it is called vitriol of lime, calcareous vitriol, selenite, plaster of Paris, vitrum muscovitum, celestine, \&c. And the vegetable alkali, known by the common appellation of potash, is termed carbonate of potash, alkahest, nitre fixed by itself, fixed salt of tartar, vegetable fixed alkali, aerated vegetable fixed alkali, cretacious tartar, mephitic tartar, mephite of potash, \&c. Who is not friglitened when he approaches a science surcharged with such multitudinous and barbarous terms? Botany is equally, if not more perplexing. Besides the Linnæan system of vegetables, we are confounded by the natural orders of Jusieu. In zoology, there are many systems besides that of Linnæus, and the nomenclature is intricate, perplexed, and various. With all these disadvantages, there is, however, no knowledge more captivating, more useful, and more dignified than the science of nature.

In my tour through the country, I have seen many organic beings, which have either been imperfectly described, or not described at allparticularly in the department of ichthyology ; and I shall probably draw your attention to some objects of this nature, of considerable interest. In making this attempt, I shall endeavor to unite 
an accurate description of the form of the animal, with some account of its mores and propertiesand I shall keep out of view as much as possible a technology which frequently bewilders, and \& minuteness which always disgusts.

\section{LETTER XXXVIII.}

$$
\text { Utica, August, } 1820 .
$$

My Dear Sir,

Mr. Roвert Fulton, the inventor of steam boats, aud the greatest mechanician of the age, estimated, from the licences granted at the custom house, that 400,000 tons of commodities are annually transported on the waters of the Hudson; and from a comparison between the country trading on that river, with the territory embraced by the western canal, he supposed that one million of tons would be conveyed every year on the latter. A toll of 50 cents a barrel, or 25 cents a liundred, on commodities, would amount on a ton from Buffalo to Albany to five dollars, and would thus produce the enormous income of five millions of dollars annually.

The only doors of escape from this conclusion, must be one or the othex of these positions:- 
Either that the toll would be too high, of that the tonnage is orer estimated.

That this toll would not be oppressive, mus? be evident from the following considerations:

1. The expense of transporting a ton of goods from Albany to Bufialo, by land, is $\$ 100$.

2. The toll lately paid for passing a ton of goods through the locks of the Western inland Lock $\mathrm{Na}$ vigation Company was five dollars and twenty-five cents, besides a considerable duty upon the vessel; and this only for a distance of 10 miles.

3. Mr. Fulton estimated the expense of transportation on a canal, one cent a ton per mile, exclusive of tolls - the expense of conveying a ton from Buffalo to Albany will amount to $\$ 553$, but if we average it at two cents a mile, it would only exceed by three cents twelve dollars, a very inconsiderable expense, when compared with the cost of other modes of transportation.

That upwards of 400,000 tons are annually conveyed on the Hudson river cannot be denied. The region comprehended in this trade, will be: in population and extent to the territory embraced in the trade of the western and northern. canals, as one is to twenty-but to reduce the ratio to the moderate complitation of one to two and an half, and then the million of tons will be made out 
The lollowing extract from a Kentucky paper will throw great light on the subject :

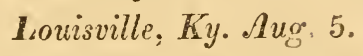

"Western navigation.-We have enumerated a list of scventy-three steam boats belonging to the western navigation, July 27, $1820 . \quad$ Several others are on the stocks above the falls of the Ohio, and two in New-Orleans. There are also several team boats in operation.

The list of vessels will aftord our distant subscribers a pretty correct idea of the extent and importance of the steam boat navigation of the western country, which must continue to increase with every succeeding year. Estimating the freight actually carried by each boat, at 150 tons on average, and that each will make three royages a year, the imports to various parts of the western states will be found to amount to 33,300 tons, and the export in steam boats will exceed that amount, while those that are made in the usual way, (in flat boats or arks) will more than double that amount. Thus our exports may be said to be about 100,000 tons.

Freights are now from 1 1-2 to 2 cents from New-Orleans to this place. The average price, however, may be stated at 2 cents per pound on articles imported from New-Orieans. 'The amount paid for fieight on inports aunually, is wow some- 
thing like $\$ 1,332,000$ to steam boats; the exports, in the same description of vessels, may be estimated at $\$ 666,000$; passengers up and down, calculating ten to a vessel, at 100 dollars up and 50 down, amount to about 333,000 dollars.

Naking the annual amount paid for freights in steam boats, about

For passengers in do. $\$ 1,998,000$ 333,000 $\$ 2,331,000$

To this sum an addition of $\$ 500,000$, at least, may be made, on account of a great number of voyages performed by ressels employed exclusively in the lower country in carrying sugar, cotton, \&c. to NewOrleans, \&c. \&c.

500,006

\section{Total, \$2,\$31,000}

Of the value of our imports and exports, no - correct estimate can be formed; nor are we able to ascertain how many persons are actually employed in the steam boat navigation of the western country."

From this statement it is pretty manifest that the exports and imports of the western states by the Mississippi to New-Orleans, do not fall far short of 150,000 tons anuually. The western canal will not only intercept a considerable por- 
lion of this trade, but will greatly increase it in the irection of New-York, for these, among other reasons.

1. The climate of New-Orleans is hostile to the greai products of the west-wheat, flour, and meats, are ruined by it.

2. The European market is the only one in which any permanent reliance can be reposed for the consumption of the staples of the west, and New-York is twenty days' sail nearer to this market than New-Orleans.

3. The insalubrity of New-Orleans is great, and a healthy will always be preferred to an unhealthy market.

4. The enormous expense of steam boats, and the delays of ascending navigation, will always make transportation more costly, more dilatory, and more exposed to loss and danger by the New-Orleans than by the New-York route.

5. When the contemplated canal from Lake Erie to the Ohio river is completed, almost all the commerce of the west will follow the track of the Western Canal.

6. The New-Orleans market furnishes an indifierent supply of foreign merchandize. NewYork is the great emporium of foreign commerce. There the country trader can obtain his goods cheap, on better credit, and with a greater expause of selection. 
7. The trader always prefers to buy where lie sells. The reasons are obvious-he saves time - he avoids expense.

If the ascending commodities conveyed from New-Orleans, and descending commodities conveyed down the Mississippi to that place, amount at the present time to 150,000 tons annually, it is not unreasonable to estimate those transported on the Great Canal, as soon as it is finished, at 500,000 tons. When we consider that the region west of Buffalo will obtain all its foreign goods through that medium, and also a considerable portion of its salt; and when we contemplate the abundance and variety of its products, and take into view the opulence, the population, the vast resources and immense consumption of the territory in the line of the canal, we cannot withhold our faith from Mr. Fulton's estimate.

Our experience on the middle section of the canal this year, cannot aftord any fair standard of calculation with respect to the future productiveness of its revenue. I should not be surprised, if the remainder of the season is not uncommonly cold, that 40 or 50.000 tons will be transporter? on it. Every year will add to its amount, and every advance to the east or to the west, will gxtend its benefits and increase its usefulness. 


\section{EETTER XXXIX.}

Western liegion, August, 1820.

My Dear Sir,

THE white fish is the most delicious fish which swims in the western waters; it is found in Lake Ontario, and in all the other lakes to the north and west as far as the fur merchant has extended his researches.

It appears to partake of the salmo and the clupea, and it unites the delicious taste of the shad and the common salmon. Dr. Mitchell has very judiciously named it salnno clupea formis.

It is of the abdominal order. The first dorsal fin is directly above the ventral, and is twelve rayed. 'The second is adipose, and is placed above the anal fin some distance from the caudal, which last is furcated. 'The lateral line is straight, waving lines cross it longitudinally the whole breadth of the fish unti! the lower part of the abdomen; the belly is carinate; the back convex, and the head sloping. The mouth is even and wide, with teeth; colour more silvery than that of a shad; scales large; size generally from three to six pounds, and it has been known to weigls en pounds. 
This fish remanis in the lakes all the year. It spawns in spring and autumu; is very numerous; and the surface of the Cayuga Lake is sometimes rippled with it to a great distance. It inhabits the Canandaigua, and probably all the parallel lakes. In the straits of Detroit, and at the falls of St. Mary, it is caught in great numbers, and put up in salt for exportation.

My description of it may be somewhat inaccurate, as I saw it only in salt. It has never been found in the eastern waters, and such is its clupea shape, that it is considered a shad by many of the inhabitants.

A species of clupea, or herring is also found in the lakes, which has been considered a young white fish. Its vulgar name is sisco, and it is a non-descript.

Its length is near twelve inches, and it is about two and a half inches in breadth; of the abdominal order ; first dorsal fin has ten rays, and is over the ventral. The second dorsal fin rayless and adipose over the anal, and near the tail ; tail forked; scales glittering like silver, and small; lateral line scarcely visible; back rising into considerable convexity, and sloping to the head; belly carinate; no teeth in jaws but in tongue: weight generally seven ounces. 
I shall name this fish clupea Bartonia, in honor of that great naturalist, Dr. Barton, formerly of Philadelphia, and whose death is an irreparable loss to the cause of science.

Several thousand barrels of this herring are salted for the use of the interior country, at $\$ 8$ per barrel. It has expelled the salt water herring from the market of the west.

The salmo salar, or common salmon, is found in Lake Ontario, and some of the secondary lakes which communicate with it, but in none of the waters above the Falls of Niagara. It is too well known to need description.

This fish, it is said, is caught all the year in the lakes; perhaps some of them remain without ever returning to the ocean. They have never been observed at $\mathrm{Ogdensburgh}$. May they not be deterred by the porpoises at Quebec from descending? 'The received opinion is, that they are naturalized to the lakes, and stay all the year. Trout in ponds run up into streams to spawn. Fishes in lakes ascend the rivers which supply the lakes, for the same purpose, and in like manner they proceed from the ocean. This is probably for a two fold object; for the safety of their young in shallow waters, and for food. The salmon of Lake Ontario go up the great Salmon river in Angus, and return in September. In some othep 
places they ascend twice a year and spawn. In Clamplain river there is no dam for seven miles, and salmon go in about the middle of April, and are good till the first of June. The Little Sable river has plenty, and also the Great Sable, because there are no mill dains. The Saranac river at Platisburgh is a rapid stream, and its bottom is sandy and stony. Formerly it contained so many salmon, that laborers, when abont to be hired, would stipulate they should not have it too often ; and the only danger in passing the ford, before the erection of a bridge, proceeded from the darting of the salmon through the water and frightening the horses. A mill dam was erected on it close to the head of the bay, and the salmon endeavored, for a number of years, to ascend, but failing, they have abandoned the ground. This fish does not ascend the Champlain Lake abore 'Ticoncleroga.

Salmon have been caught in the Oneida Lake, and Lake Champlain, by the hook. Some of the lakes and ponds are filled in July, August and September, with the ova and teguments of aquatic insects, which substances go under the name of lake blossom. The ova are hatched on the surface of the water, and the winged insect flutters a sloort time in the air cluring the process of jecting the ova, after which it perishes in a short 
time. During this state of these insects, the salmon and other fishes fare luxuriously and disdain the hook. In July the salmon of some of the small lakes are greatly annoyed by aquatic insects which fix on the gills and fins, and eat the latter so that the fish can hardly swim. It is supposed by some, that they go up into the creeks to get rid of this annoyance. The salmon has small, short teeth, and is undoubtedly carnivorous. When most assailed by vermin, it is the fattest. The greatest weight 48 pounds.

\section{LETTER XL.}

\section{Western Region, Augusi, 1820.}

MY Dear Sir,

THE black, or Oswego basse, stands at the head of the perch family of this country, for delicacy of flavour. He is eagerly sought for by Epicurean avidity, and when he is properly prepared for the table, he is as much prized by the Amcrican gourmand, as the green turtle is by a I.ondon alderman.

This fish is of the perca genus, and thiracie oraler, aldhough the ventral is in strictness not directly under the pectoral fin, yet I place him in 
this order as has been done in several other instances of a similar nature.

He has two dorsal fins; the first is spinous and formed of eight rays; second over the anal; tail furcated considerable distance from anal fin; head leathery; skin blackish and tough; uncer lip juts out a little beyond the upper; mouth remarkably wide; belly carmated; blackish color in body, tail, head, and fins; belly lighter on both sides; teeth in both jaws; the outer circle of the eye golden colour.

This fish inhabits almost all the western and porthern waters. He is called black on account of his colour; - Oswego, because he was first paricularly noticed at that place; and basse is a Dutch word corresponding with perch. He is a non-descript, and as I think his good qualities entitle him to a distinguished name, I have thought proper to call him Perca Frantilinici, in honor of Dr. Franklin.

This fish appears the latter end of June, and stays till the cold weather in October and November. He is caught with the hook, and in trolling bites with avidity at a red rag. He is armal with strong teeth, and is predaceous. $\mathrm{He}$ is considered very large if he weighs six pounds, but in Lal:e Genrge he has been known to reach seven and a half pounds. He makes his 
bed in shallow water, on the margin of deep water, by scooping the sand in the shape of a circle, drep at the centre, and sloping gradualiy from the periphery. In the centre che ova are deposited in fine sand, and as you glide over the waters of the Lake, you can see the fish in the circle, incum bent sometimes over the ova, and at other cimes darting with fury, and driving of all strange fish that approach its nest. The power of parental affection is manifest in this case, and the storge prevails in fish as well as in all other animais, as long as it is necessary to be exercised for the preservation of the young. The eggs it is necessary to defend, but the fry can escape into shallow water. This fish spawns in June; its offspring are numerous. I have canght him with the common angle worm; when he strikes the hook he vaults up, and if pulled with too much violence, the ligament of the under jaw is broken, and he escapes. When he springs fiom the hook, he shakes his head to extricate his mo:th; and he should therefore be drawn up with all possible expedition; and if unsuccessful in that way, he will run off with such violence, as sunetimes to b:eak the strongest hair line. This fish formerly abounded in Lake George, where he exercised dominion without a rival, there being no pike to contest his ascendancy; but in late years he is 
said to diminish in number, and to have retired towards the foot of the lake, and that scarcity is observed in all the other fishes, and is imputed to the erection of so many saw mills, and to the burning of the pine forests on the mountains, which it is supposed frightens the fish into deep water. The waters of Lake George are, I am told, impregnated wh lake 67ossom in June and July. This is unrionbtedly the ova and exuvice of aquatic insects, from which fish derive at certain seasons their principal subsistence. How easy to mistake for this food the suw dust which is unquestionably the principal cause of the destruction of fish, although undoubtedly the increased angling has had a tendency to thin their numbers, or to terrify them from the hook. This fish is excellent for the three first weeks in August, when it retires to the shallow waters, and feeds on grass and snails. He is prepared for the table by frying and boiling. Before frying it is best to skin him; and when boiled, let him be thrown into hot water, and ten minutes are then sufficient for this operation.

It appears not only in this case, but in that of many others, that fishes disappear for more than half of the year. To what place do they retire? From Lake George there is no escape into other waters. They must go into the deep waters. 
And are they there in a state of torpidity? Probably not all the time. In those deep, and almost unfathomable recesses, they probably find appropriate food, and when the power of propagation is set into operation, they emerge from the great deeps of the lake, to enjoy the genial influence of the sun, and to afford food and security for their offspring.

\section{LETTER XLI.}

Western Region, August, 1820.

My Dear Sir,

I HAVE had an opportunity of seeing the rattle snake, a serpent peculiar to America, and whose natural history is greatly involved in fable and mystery. Its venomous qualities have been some. what exaggerated, and the antidotes against its poison have been much misrepresented. It has a brown, broad head; the jaws are furnished with small, sharp teeth; four fangs in the upper jaw, incurvated, large, and pointed; at the base of each, a round orifice opening into a cavity, that near the end of the tooth appears again in form of a small channel; these teeth may be crected or compressed. When in the act of biting, they force out of a gland near their roots, the satal 
Juice; this is received into the round orifice of the teech, conveyed through the tube into the channel, and thence with unerring direction into the wound.

Appended to the tail is a crepitaculum or ratele, a crustaceous substance composed of joints loosely connected; each distinct joint, or compartment, denotes a year of the life of the animal, and the number of joints indicates its age, after the third year, but according to some observers, after the second, and in the opinion of others, after the first year. Linnæus has arranged the crotalus genus under four species, and his specific difierences consist in the number of plates of the belly and tail. The crotalus horridus, or common rattle snake, has, he says, 167 plates on the belly, and 23 belonging to the tail. In the common acceptation of the country, there are but two kinds; upland, which is large, and a small hind, which inhabits swamps. It was denominated by Nieremberg, an old author, domina serpentum.

The one I saw was caught near the cataract of Niagara. Charlevoix observed in his tour to the west, a great number in the vicinity of this celebrated place. They are said to have a den in a forest a few miles off, and there is also another den about 15 miles east of Lewiston, near the causeway. A small island near Grand Island, in 
the Niagara river, was called Rattle Suake Island, from the number which it formerly contained. Twenty-five were killed on it in one day, and none are now to be found there.

It is generally believed that they are devoured by hogs with impunity and with avidity; this is confidently denied; and again it is said that deer kill them by springing on them with collected feet. $1 \mathrm{t}$ is certain whatever may be the fact in these cases, that they disappear before population.

Venomous and dangerous as this animal is, yet a lady of fortune from Carolina carried about one as a pet. In the house where she boarded in New-York, her fellow lodgers were much alarmed one evening by observing several young rattle snalies about the rooms. It appears that they had escaped through the holes of the case where the mother was confined, and where she had brought forth her young.

I believe that all venomous serpents come under the description of ovi-viviparous; that is, that the ova are hatched internally. A rattle snake was recently killed near the western canal, which had thirty eggs in it. This shows that they may have thirty young, although the general impression is, that their offspring cannot excecd twelve at one time. It is believed by many that the 
young retreat for security into the body of the nother, although this is confidently contradicted, as well in this case as in the case of the viper. 'That both are viviparous is certain.

Round Lake George, on the mountains, there are said to be at least 100 dens. There is one eight miles down the lake on East Mountain, and there are five others two miles from the head of the lake. There are two great dens within six miles of Ticonderoga-one at Rogers' rock, four miles from the foot of the lake; and the other about three miles ofi, on the east side of the lake. These suakes generally select a south eastern or sumny ravine on a mountain, for their hybernacula. They descend deep into the cavities of rocks, and look out for a position at the head of springs. The vulgar believe that they will not bite in the spring nutil they have tasted water, and that they lave a king distinguished by a carbuncle, and "which, like the toad, ugly and venomous, wears a precious jewel in his head." This serpent frequently swims across lakes and rivers. Several persons dug for a den on the side of a mountain near Lake George, and after digging 15 feet they were arrested in their pursuit by a great rock, under which there were two holes large enough for a man to enter, from which ascended volumes of noxious exhalations, that were attributed to col- 
lections of snakez coiled torether. They are eagerly sought after for their oil and gall, which are used in sprains and rheumatisms; and for their fiesh, which has been applied in consump. tions; and they are frequently destroyed by fires made accidentally, or for clearing the woods, and sometimes they bite with great fury at the firmes. Owing to these causes their numbers are much diminished, and they are ouly preserved from extirpation by the fastnesses and cirp recesses of the momtains.

During the late war, a detachment of the American army was encamped two miles north of $\mathrm{Ni}$ agara, at a place called Snake Hill, whicis was greatly annojed by rattle snakes. In order to leep them of 3 , the tents were surrounded by bonghs of the ash tree, which preventive, heretofore consiliered certuin, was found unava!ilig.* Some were lilled on the parale, and one morning a soldier shook two ont o! lis blanket. This country is champaign, and the is no moustain nearer than cight miles.

Is it true that ratte sualies are linled every

* This notion may be tracel back to Pliny, who nserrts is ia

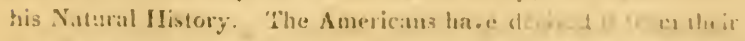

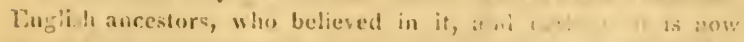

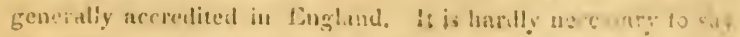
thint it is entircly untomated. 
year on York-island, about eight miles from the city, near the great strata of geneiss? I am told that some years ago a large one was found in a populous street of that city; and that it was supposed to have been lost by its keeper;-may it not have emigrated from its den on the island?

As soon as the warmth of the season will permit, this serpent evacuates his den, and traveis at his leisure about eight or ten miles from it, where he continues until September, when he returns to his winter quarters, most terrifically furious and ferocious. He couples in August, and produces gext June.

\section{ietTer xlí.}

\section{Western Region, Augiust, 1820.}

Mir Dears Sir,

Wres the ratte snake intends to bite, he coils himself up like a cable, and then extending his head, throws his whole body forward with rapidity and fury at the object he intends to strike. Sometimes he makes a hind of singing noise, and when he rattles he does not mean to wound. All snakes are very irritable when in coition, and the crotalus is very dangerous from this period to the time of his hybernation. 
I have already mentioned the failure of an experiment relative to the efficacy of white ash against the approaches of the rattle snakc. I have been told of a rattle snake that had been kept in a cage eight months without food, and without any apparent dininution of bull. Although furious when enraged, it is alleged, that he would not bite at a white ash stick. And it is asserted, that if you enclose this serpent by a circamvallation of white ash leaves and fire, that he will elect to make his retreat through the flames.* It is said that the juice of the leaves of the ash has been found efficacious against the bite of the coluber chersea, the asping of the Swedes, which like the prester of Lucan, kills by a horrible swelling of the whole human frame, and which inhabits only a particular district of Sweden among the willows. It is certain that there are districts of country in which rattle snakes are never seen. while at no great distance they abound. For instance, they have never been known to inhabit the town of New-Berlin, in Chenango county, and yet they have been found about ten miles off, towards the mouth of the Unadilla. It is said that they avoid land timbered with beech and maple. Whether the cause arises from the timber

* This superstitious idea was refuted in a note to the last number. 
or the soil which produces it may be a question. White oak land is preferred by them. The small species generally live in open swamps, and their bite is not considered so dangerous.

Some negroes killed 315 rattle snakes a few springs ago, by smoking them out of a den at the south end of Canandaigua Lake. There are many about Eighteen-mile creek, in Genesee county, where they inhabit the open ledges and fissures in the rocks, and there are dens in the mountains on the south side of the Mohawk river, at a place called the Nore, in Montgomery county. A great den exists on the east side of Genesce river, near Rochester. In the spring they travel west, (as their heads are then found in that direction) ten or twelve miles, and scatter themselves over the low lands; and for this purpose they swim across the river. In autumn their heads are pointed to the east, as they then returin to their den. In August 1816, a monstrous rattle snake was killed at New-Mills, New-Jersey, which had eleven rattles, and was five feet long, and which was the only nue seen for several years within many miles of that place: and some ycars ago, in the vicinity of Lake George, a whole den of rattle snakes migrated from one mountain to another. 'This was in the autumn, and was inquestionably clone for a more sccure and comfortable residence. 
Fancy has assigned to the lordly rattie snakc an attendant, or minister, like the jackall of the ling of the quadrupeds. This is a venomots viper, with a flat lead, and a body coloured like the rattle snake. It has no crepitaculum, and is called the rattle snalie's pilot.

I have been told, but I have had no opportunity of ascertaining the fact, that the rattle snake differs from all others, for that when skinned, the whole body becomes open to the back bone, and and that no intestines are visible except the heart.

It appears that the rattic snake is not singular in the selection of his winter quarters. Thunberg. spealis of a mountain, or rather a large single rock, in the Cape Colony, in Africa, called Slangenkof, (serpent's head) on one side of it is a large and deep crevice, which makes this rock remarkable, for every autumn the serpents go there and coil together, and come out in summmer. The poison of the serpent has most power over those animals whose blood is the warmest, and the action of whose heart is the most lively; while on the contrary it is said not to be a poison to the serpent itself, nor to its fellows, nor in general to cold-blooded animals. I have heard this remark contradicted in relation to the bite of the rattle snake, although $I$ believe it to be true of the viper tribe in general. $A$ person saw two 
engaged in battle-at last one bit the other, which immediately retreated, and died in a few minutes. It was supposed that it went of rapidly for an antidote.

To show the rapidity of the bite, and the mortality of the venom, the following anecdotes were related to me: A man in pursuance of a common practice of killing snakes, took a rattle snake by the tail from under a log, and snapped of its head like the cracking of a whip; he was bit in the thumb, without knowing it, during this rapid opesation, and died. Another one killed a rattle snake, and cut of the head about five inches long, and ordered a boy to bury it; not obeying the order fast enough, and being hurried in his work, the man took hold of the head, which turned zound and bit lim so that he died.

The same serpent possesses very different dtgrees of power in its bite, according to time and circumstances. This is beautifully intimated by. Virgil when speaking of a serpent common in Italy in his time.

"Est etiam ilie malus Calabris in saltibus anguis, Squammea convolvens sublato pectore terga, Atque, notis longam maculosus grandibus alvum: Qui, dum amnes ulli rumpuntur fontibus, et dum Vere madent udo terræ, ac pluvialibus Austris, Stagna colit ; ripisque habitans, hic piscibus atrans inprobus ingluviem, ranisque loguacibus explet, 
Postquam exhausta palus, terræque ardore dehiscunt,

Exsilit in siccum: et flammantia lumina torquens,

Sævit agris, asperque siti, atque xterritus æstu.

Ne mihi tum molles sub dio carpere somnos,

Non dorso nemoris libeat jacuisse per her herbas ;

Cum positis novus exuviis nitidusque juventa

Volvitur ; aut catulos tectis, aut ova relinquens, Arduus ad solem, et linguis micat ore trisulcis."

I am told that rattle snakes have been seen on Long-Island, and at Snake Hill, near Newburgh. There is a beautiful island called Diamond Island, containing about an acre of land near the head of Lake George, and it is said that it was formerly so overrun by ratile snakes, that travellers shipwrecked there were forced to lodge one night in the trees, and that the serpents were extirpated by hogs brought there for the purpose.

On the south side of a momntain west of this lake, and at the head of it, there is a large den of rattle snakes. At the village there lived a professional rattle snake catcher, who hart taken in one season 1300, and who made a livelihood by selling the oil and the flesh, and by vending living ones for shows. He went out as usual, with a large basket covered with a carpet, and was found dead after an absence of some days. In carrying the basket, it is supposed that the covering fell off; and that one of his serpents bit him in the side, as he he was much sivollen, and there was 
found by him a rattle snake clit up, which it is !) resumed he had applied to the wound.

\section{IETTER XLIII. \\ Western Pegion, August, 1820.}

IIy Dear Sir,

Some of the distinguished naturalists who figured in the world after the resurrection of letters, adopted an analytical or rather methodical way of discussion, which was admirably calculated to illustrate natural science, and to facilitate instruction. For instance, in treating of birds, they would describe the genus in extenso, and then. would give a particular account of each distinct species, under the following heads; sometimesomitting, and sometimes adding to the specifications.

Forma-descriptio.

Locus-Natura-mores-ingenium:

Nidus-partus-victus.

Vox-cantus-volatus.

Capiendi ratio.

Usus in cibo.

Usus in medicina.

These accounts were mingled with great inacuracies, and numerous. fables, but yet they 
abounded with all the fertility of genius, and evinced uncornmon research and indefatigable industry. Our modern naturalists, with some distinguished exceptions, confine their attention almost exclusively to the forma et descriptio; and natural science in their hands has become a study of hard words, instead of the study of animal, regrctable, and mineral nature.

In the few illustratious which I have given of the zoology of this country, I have consulted accuracy instead of wandering into the flowery fields of fancy. My stock of information must necessarily be very limited so far as it depends on my own observation-and my opportunities for deriving information from others have not been many. The hints or intimations which I throw out may serve sometimes as clues to more interesting investigations, and a wider field of natural science was never afforded than that which this country furnishes.

In various places I have seen the falco leucocephalus, or bald eagle; the falco ossifragus, or grey eagle; and the falco haliatus, or osprey. In Turtius Limneus the osprey is confounded with the grey eagle, but this is an error of the editor, not of the immortal author; and Wilson supposes that the grey eagle is a junior bald eagle, which has not arrived to maturity. It is wel! 
known that the osprey is a purveyor for the two other liuds of Eagle-and that they compel this skilful bird to surrender the fish which he catches so abundantly.

The immense quantities of fish which collect below the falls of Niagara, and which inhabit that river and the mouth of Lake Erie, necessarily draw togrether these birds, and I have never seen so many as appear to occupy this region.

I shot a bald eagle which measured eight feet from the extremity of one wing to that of the other. His talons were so formidable, and his courage so great, that after receiving his mortal wound, he beat off several dogs in a pitched battle; and I was told of one which was lilled near Canandaigua, and which weighed 14 pounds. It had actually killed several sheep. I have seen both kinds near the Catskill mountains, where they erect their aeries on the loftiest trees, and where they soar in "eagle-winged pride." And yet $\mathrm{I}$ have beheld this imperial bird fly from a tree on which a crow had lit. I have seen him avoid the annoyances of the king-bird, and retreat before a congregation of ospreys.

A grey eagle was shown to me which must have been full grown. It was the size of a bald eagle, and had been shot in the wing about twelve months before. Its colour was a darkish brown 
all over, with the exception of the interior feathers, which were whitish. The cere was also whitish. The bill was of a darkish colour to the cerethat of the bald eagle is yellow.

Three eaglets were found in a bald eagle's nes: at Lewiston, and I was informed that some years ago four were caught in an aerie on the highest button-wood tree in the forests of that country. -The nest was as large as a cock of hay. In making it, the old eagles made use of the limbs of the tree which were broken off as thick as a - man's wrist. The aerie had been there twenty years, except during the late war, when it was built on a tree in an open field, the inhabitants having moved off. The tree was cut down fo: the purpose of getting the young. One of them was carried to the village, and the old ones followed it to the house where it was kept, recognized it, and flew about the place of its confinements One of the other eaglets was carried to the fort, and it is said to have been larger than the other. Whenever a stranger appeared, they ruftled their heads, and indicated great irritation. They made a mournful noise when annoyed and were very ferocious. One of them had engaged the af rtions of a clog, which brought him garbage whenever he could obtain it. 
An intelligent man in whose veracity I have confidence, says, that the bald eagle is cntirely distinct firoin the grey-that he camnot be mistaken in his opinion, for that he has secn the male of each species in connexion with his appropriate female.

Lawson, in his history of Carolina, says that the bald eagle breeds very often, and lays egg: again under the callow yourg, whose warmth hatches them. The same thing is said of the picus auratus of this country, vulgariy called higit hole. These allegations ought to be investigated, as they furnish, if true, a singular anomaly in natural history. With respect to the eagle it is probably true, if half of what is alleged by one of the early Naturalists is correct. Johnston, in his elaborate work printed at Amsterdam MDLVII. speaking 'De aquila in genere,' says_- Datur geus quod propter tres testiculos, Triorchis appeliatur. Coeunt vero frequenter ; et fremina terdecies in die compressa, si masrevocet, denuo accurrit. Unde Egyptiis et Venus dicitur, et soli dicatur. Commiscentur aliquando cum accipetre, sed ovis incubare non dignantur; sed et marem cum lupa aliquancio coire scriptores $A$ fricani referunt."

Charlevoix says that his people threw down, near Oswego, an eagles' nest which was compo- 
sed of a cart load of wood, and that it contained two eaglets, which were not as yet featheredthat they were eaten, and made very good food. I think that Boccacio in his Decameron, serves up a falcon as a choice dish.

The Americans have selected the eagle as the symbol of national power. In the ancient mythology he was the bird of Jove, and in all nations he is the sign of strength and majesty. His eye can see to an immeasurable distance, and his flight is as rapid as the vollied lightning.

\section{LETTER XLIV. \\ Westem Region, Augurt, 1820.}

Mr Deale Sir,

On my way to the west I passed a few day's a Albany, and among other public places I risited the Muscum of Tatural History. Here I saw the largest of the cervus genus called the moose. It was mounted in the museum. Its height abore the shoulders f t feet, aml its weight $1000 \mathrm{lbs}$. Its homs had fallen of before it was killed. Tweny-live it is said were lilled in the comntry north of Whitestown last winter, at different times. This one belonged to a leerd of five: 'The great Acpth of the snow bicilitated the suecess of the 
hunter. Under the throat there was a wattle pendant from it, and at least nine inches longbeing an excrescence covered with long, coarse, black hair. Upper lip broad, and hanging over the lower-cars long and standing-nose broad -nostrils large-neck shorter than the headalong the tip a short thick mane-body brownish -hoofs large-horns with short beams spreading into large broad palms, the iuside of which is smooth, and the outside furnished with several sharp snags. The horns have weighed 60 ibs. Although this stufied moose had no borns, yet I have inspected two sets of horns which had fallen from others.

This animai is called by Linneus cervus alces, and he is confounded by several writers with the ejk of America, called by Dr. Barton cervus wapitê. Tisese animals are specifically distinct from the eils and stag of Europe. The American moose has been styled by some naturalists the black moose; and the Amcrican elk, the grey inoose, to discrininate them from each other. The moose is confined in his range to the cold regions of the north, while the elk has been seen from Canada to Nexico.

I am told that two young moose were sold at Utica some years ago for five hundred dollars. This animal lives cntirely by browsing. He trots: 
twenty miles an hour; is docilc, and can be casily tamed; and is only dangerous, like all other deer, in the rutting season. Sir John Wentworth, Governor of Nova Scotia, had one in his park, and as his company were assembling at dinner one day, they amused themselves with looking at it, running about in a furious manner, and it fnally pushed over a small building from which the house-keeper crept in a state of great confusion.

He is more easy to tame than any of the deer family. He has been frequently kept at Churchill, as tame as sheep, and even more so, for he would frequently follow his leeper any distance from home, and at his call return with him, without the least trouble, or ever offering to deviate from the path; and Hearne reiates that tiie same Indian who had brought the above mentioned young moose to Churchill, had, in 1775, two others so tame, that when on his passage to Prince of Wales's Fort, in a cance, the moose always followed him along on the bank of the river, and at night, or on any other occasion when the lndians landed, the young moose eenerally came and fondled on them, in the same manner as the most domestic animal would have deue, and never offered to strny from the tents. Unfortunately, in crossing a cleep bay in one of the lakes on a fino 
day, ali the Indians that were not interested iu the safe landing of those engaging creatures, paddled from point to point, and the man that owned them not caring to go so far about by himself, accompanied the others, in hopes that they would follow him round as usual; but at night the young moose did not arrive, and as the howling of some wolves was heard in that quarter, it was supposed they had been devoured by them, as they were never afterwards seen.

I have also seen several live elks. This anima! is called by Catesby, cervus major Americanus -by Jefferson, alces Americanus, cornibus teretibus, or round ho:ned elk-by Clavigero, the alces of New-Mexico-by Barton, cervus wapitè-and he is confounded by Pennant with the moose, and described by nim as tue siag. The male has a beard under his throat and upon his breast-(caruncula gutturalis) a short mane-tail very short - the femalc bas no homs. The horns are not palmated like those of the moose, but are rounded, and consist, 1 st. of the brow antlers. 2d the two middle prongs, sometimes called the fighting horns: and $3 \mathrm{~d}$. the horns, properly so called. His horns do not commonly drop till June, but sometimes as early as April. Under the interior angle of cach eye, there is an oblique slit, of aperture, about an inch in lengih, which is said th 
communicate with the nostrils. By closing the Hostrils, it makes a whistling noise, by forcing the air through these openings. This organization is probably auxiliary to smelling, and this structure which is termed sinus lachrymalis, or sinus sub-ocularis is found in the fallow deer, and in most of the antelope genus.

The greatest altitude of this animal is not five feet. I saw a male which with two females had cost fifteen hundred dollars; he had cast his horns about the middle of April, which is earlier than common. Colour dun, except towards the posteriors, which is whitish. When the male is angry, he strikes with his feet, and is very dangrerous.

This animal differs from the moose,

1. In conformation of body.

2. Shape of horns.

3. Inferior size and height.

4. In its adaptation to a southern clime.

And I trust that they will not be confounded to. gether in future. Let the moose be denominated exclusively cervus Americanus, and the elli cervus wapite. 


\section{LETTER XLV.}

\section{Western Region, August, 1820.}

My Dear Sir,

Ix a late letter I attempted to show that the 1. was continually gaining on the lakes, by the i.- acy of calcarenus depositions, and I think that I asted ont a region of schistic formation, lying s whi of the great lime stone ledge of the west. inat this caicareous formation dips to the sonth, I have no doubt, but whether it underlays the schistic, I have not been able to ascertain. This soutierin depression of the calcareous ledge below the crumbling slate, would nccessarily create ba. sius for the springs and rains of the country, and whicls by wearing away that fragile substance, would in time expand into lakes. This is evidently the case with the Cayuga lake, which is continually enlarging its borders; and the fall of old bedes from the precipices demonstrates that the prescnt order of things has no: been of very remote antiquity.

The shores of Lake Erie are sustained by strata of schistic which are continually giving way before the vinlence of the waves, and the whole lake is supposed to be in a state of continual expausion. 
'These slate roclis are in some places fifty feet high, and have been worn away in several places more than eighty rods; and as this operation has been carried on with a steady progression, there might perhaps be some means discovered of ascertaining the time of the process. It is supposed that a probable datum might be obtained by examining a number of the trees which grow in at thin layer of earth on these rocks, and which have been undermined by the rock falling off. Losing their support and nourishment on that side, they die, while the other side is supported and nourished, and continues to live and grow. By inspecting a number of trees in this situation, and ascertaining their age by the concentric circles since they lost their support, and comparing that with the extent of the wearing away of the rock since that period, a pretty accurate measuresnent of the time of this operation might be established. Of the certainty of this process there is the most unquestionable evidence. Near the Fightecin Mile Creek, about fifteen miles from Buffalo, a thin bed or sheet of lime stone appears in a high perpendicular ledge of slate. It is about a foot in thickness, and lies in its bed, broken as it were by perpendicular fissures into small blucks. It commences with the slate at its surface, which surface is nearly horizontal, but takes 
the same course with the plane of its lamina which dips something less than a degree to the north-west. The edge of this calcareous sheet is visible for more than half a mile, projecting generally two or three feet out of the schistic ledgre to the place of its descent below the surface of the lake; and there it is scen uncovered for some distance, and extending into the lake more than a quarter of a mile, to the termination of the slate. rock, and to the place where the water becomes very deep. When this lime stone lay above the surface of the lake, the action of the water has worn away the subjacent slate, and the calcareous blocks fell off; but as these blocks are much harder than the schistic, they are of course a longe' time in wearing away. They are however found extending from the ledge many rods into the lake, and in a state of graciual diminution, the outer sides being ground down to pebbles. These appearances exist in other places, and warrant the conclusion, that this schistic barrier once extended very far into the lake.

While the south shore of Lake Erie is surrounded by schistic, that of Lake Ontario is supported by lime and sand stone, much harder substances.

These intimations are certainly deserving of a more critical examination, and since I am on the subject of geology, I shall exhibit to you an 
interesting outline, which I know, so far as my observation extends, to be correct, and which a friend of mine dcrived from an ingenious gentleman of the west.

A ridge commences at the Little Falls on the Mohawk river, and from thence takes a south westerly direction, until it passes the south end of the Seneca Lake; from thence it turns, and and continues nearly a west course, until it enters that part of the state of Ohio called New Connecticut. It there diverges to the south west, and expands into a level country. It however, maintains nearly the same horizontal level, and passing round the south end of Lake Michigan, bends to the north, and continues in a northerly direction between lakes Michigan and Superior on the one side, and the riverMississippi on the other, keeping that course even beyond their waters, and forming the height of land that embosoms the Lake of the Woods, and the other lakes in that region. It may be observed that this ridge divides the waters that fall into the Mohawk, One tario, Erie, Huron, Michigan, and Superior, on the one side, from those of the Susquehannah, Allegany, and different branches of the Ohio and Mississippi on the other. Near the Little Falls, and until it passes the head of Seneca Lake, on the northerly side it forms in many places a hilly 
or broken surface. From Seneca Lake until it passes into the state of Ohio, it is for the most part abrupt on the north side, but on the southeriy side, from its summit, the country descends with a very gentle and almost imperceptible in. clination to the south west.

\section{LETTER XLVI.}

\section{Cataract of Niagara, September, 1820.}

My Dear Sir,

Lewiston is about seven miles from the Falls of Niagara, and in passing from the former to the latter place, I observed on the top of the high hill or slope of Lewiston, the remains of the old way by which the French drew up their goods which shey sent round the cataract. A crane was fixed on the summit of the hill, and an inclined plane down the descent, in which sleighs were placed, and as articles were conveyed up in one vehicle others were let down in another.

About two miles from Lewiston, the Devil's Hole is to be seen. It is a monstrous chasm, or ravine, close to the road, and $\mathbf{1 5 0}$ feet deep, where the hill is upwards of 300 feet above the level of Niagara river. It is formed by a small creek caled Bloody Run, precipitating itself into the bank, 
This sanguinary name is derived from this circumstance: After the capture of Niagara by Sir William Johnson, in the war of 1756, commonly called the French war, an escort of thirty English with waggons, were driven down this precipice by an ambuscade of French and Indians, and all killed, except one who broke through the enemy. and another who was caught by a tree on his descent, and although miserably wounded, was living a few years ago to narrate the melancholy event.

Two miles from this place, is the whirlpool of the Niagara, which exhibits the power of water in the most astonishing manner. When the largest trees of the forest are involved in the vortex of this fresh water Maelstrom, such is the fury of its vertiginous motion, that they are whirled round with inconceivable velocity, and after being precipitated into the great abyss of water, and lost to the eye for a considerable time, they are either cjected in fragments from their prison, or entirely demolished.

The celebrated cataract of Niagara has been delineated by so many travellers who have visited it from La Houtan, Hennepin, and Charlevoix, down to Weld, Volney, and Schultz, that I shall not attempt to add to the number by a formal description. It has been the subject of painting, as 
well as of writing, but neither the pen nor the pencil are adequate to afford a competent idea of its sublimity. You recognize at a great distance this astonishing place, from the ascent of vapors, and the clouds which are always hanging over it, and you hear the roaring of the waters like the sound of distant thunder. At Fort Schlosser, upwards of two miles above the falls, by water, the river narrows, and rapids commence, of irresistible force, and immense velocity, and extend to the falls. The noise, agitation, and fury of these rapids, constitute as great a curiosity as the cataract itself. An island called Goat Island, containing about eighty acres, runs up to the falls, and divides the waters. Here the whole river precipitates itself headlong over a perpendicular ledge of rocks, $\mathbf{3 6 2} \frac{1}{2}$ feet, according to an accurate measurement of the descent. The greater part of the mighty mass passes over on the west side, and viewed from the American bank appears green, in the thickest part of the cataract, whereas the volume of water on the east side, when seen from Table Rock, looks white, which may be owing to its inferior density. There are cataracts which exceed this in altitude, but there is none in the world which approaches it in volume of water. Below the cataract there are large rocks, which have been torn and burled from their foundations by 
the rapids, and some yerrs ago, an immense mas of the rocky stratum was precipitated orer, and shook the country round like an earthquake.

Ovid's description of a cataract furnishes but a very imperfect idea of this wonder of nature.

"Est nemus Ftmonix, prærupta quod undique claudit

Silva : vocant Tempe. Per qux Pencus ab imo

Effusus Pindo spumosis volvitur undis,

Bejectuque gravi tenties agitantia fumos

Nubila conducit, summasque aspergine silvas

Impliuit ; et sonitu plus quam vicina fatigat."

This cataract is a great manufactory of clouds and rainbows, and it serves as a barometer as far as Buffalo. If the spray spreads from the north it is a sign of a northerly wind.-A south east wind indicates rain.

Goat Island derives its name from its being appropriated to goats by Mr. Stedman, the former possessor of Fort Schlosser. It now belongs to individuals, and is comnected with the right bank of the river by bridges. It was formerly supposed that it would make an excellent place for a state penitentiary on account of the impracricability of passing from it previous to the crection of the bridges; but this is a mistake. It cau be easily reached by a canoe from the place where the rapids separate at the the head of the ssland, but it is difficult to retire. Stedman used 
to ride to it on horscback, and I saw a man who had planted potatoes on it in former times. I observed trees on it, on which are inscribed the names of visitors as far back as 1769. A slielecon was found buried in a grave, and indications of a canoe being made about 40 years ago were also observed. I heard the singing of locusts and birds. It is covered with large trees, and the soil is uncommonly good, being composed of a fine regetable mould. This island was formerly the place where eagles erected their aeries, as well on account of its seclusion, as its propinquity to the carcases below the falls. Some years ago a Jarge deer was seen for two or three weeks wading a short distance into the rapids from this island, and retreating. He had been drifted down from above, and not knowing the safe passage to the shore, he no doubt was carried over the falls. Volney says that he found at the bottom of the precipice the carcases of some deer, and wild boars, which the current had hurried down the cataract on their attempting to swim across the river above it. As there are no wild boars in this country, this shows how inattersive the most observing traveliers are to objects of natural history. It is generally supposed that every animal is deprived of life which passes over the falls, but this is a mistake. Tame geese frequently escape: 
A dog once got clear with a broken rib; and two sheep were found below the cataract, one of which was alive. On the other hand, the probability of escaping with life is scarcely any. Wild geese, deer, fish, and other animals, are to be seen dashed to pieces. A tragical story is told of a poor Indian, which would form a good subject for a poem. He had tied his canoe to the shore at Chippewa, and had fallen asleep. Some ruthless villain, it is supposed, loosened his fastening, and he floated down. When he got involved in the great rapid, he was awakened by the noise, and rising up, and perceiving his perilous situation, he tried with all his might to pacidle himself out-but finding his efforts unavailing, he wrapped himself up in his blanket, and sat down in the canoe, yielding himself up to his fate with stoical apathy, and with Roman fortitude. In this short and dreadfu! interval between life and death, a poetic imagination might conceive and describe with wonderful pathos and energy, the illeas which passed through the untutored mind of the poor Indian, and the feelings which agitated his bosom, when un the ave of a tinal separatiou from his family and sacred home, and when the ties which connected bim vith this world, were about to be for ever clissolved. 


\section{LETTER XLVII.}

Cataract of Niagara, September, 1820. líy Dear Sir,

I BELIEVE that in a former letter I mentioned the nature of the rocks which constitute the precipice of the Niagara Falls. The substratum is a compact fiesh red sand stone, infusible before the blow pipe, but is rendered friable, and retains its color. The upper strata are composed of carbonate of lime, of immense volume and density. This sand stone becomes brittle when exposed to the atmosphere, and as it descends it increases in fragility. About two miles north of the cataract, there is a sulphur spring near the river, where the sand stone is the lower stratum. At a consideraBle distance down the Devil's Hole, the same rock appears, and also near the bottom of the great ridge, or slope, at Lewiston. The country above he heights of Lewiston and Queenston is a vast plain, from which there is an abrupt descent of sear three hundred feet, into another plain at Lewiston, and in which plain is Lake Ontario. The upper slope is table lard, as well as the plain below, and this produced the French denomination of Upper and Lower Canada. The river 
divides the slope between the heights of Lewiston and Queenston, which is composed of the same materials on each side. This fact in connexion with the scanty covering of earth which the rocks on the top of the bank retain in other places on the western shore, and the parallel arrangement: of alluvial earth on the eastern side, now two hundred feet above the surface of the river, furnishes proof little short of demonstration, that the Niagara river has sawed through the rock from Queenston to the present falls. At the heights of Lewiston the upper stratum is composed of solid masses of lime stone resting on red indurated brittle clay, then at a great distance from the top, and below this clay, a stratum of red sand stone, twelve or fifteen feet thick appears; thence to the bottom of the precipice red and blue indurated clay and stones of the same colour, chiefly red.

At Black Rock, and at. Bird Island, black flint abounds embedded, but not incorporated in lime stone, and the lime stone ledge which supports Lake Erie dips to the south. The bed of the river from Lake Erie to the falls, is composed of lime stone. From Lewiston to Lake Ontario, a distance of seven miles, the bank of the river is composed of red indurated clay; and the village of Lewiston is one hundred and twenty-three feet above the level of the river. 
Lake Erie is elevated 541 feet above the tide water at Troy, and Lake Ontario 206 feet.

From Lalie Erie to Fort Schlosser there is a fail of

\section{5 feet}

To Lewiston, say

.332

To Fort Niagara, say

334

The upper strata of this region from Lake Erie to Lewiston, are formed of calcareous rock of various kinds, which rests upon sand stone, hiefly red and friable, and which reposes on red lay, chiefly indurated. In comparing the appearances of stone with the stratified levels, the continuity and identity of the former will be obvious.

The chasm at the bottom of the cataract is 347 feet deep of water. A beautiful white substance is found here-supposed by the vulgar to be a concretion of foam, consolidated by the power of water-but it is carbonate and sulphate of lime, which has been reunited after being in a state of solution. The lamellar gypsum found here is very fine, as well as the white amorphous.

The recession of the falls from Lewiston and Queenston, is easily explained on this geological view of the country. The fragile materials which compose the foundations of the great calcareous rocks are continually and gradually wearing away by the action of water, and by a partial exposure to the atmosphere; the removal of the 
sub-strata will necessarily produce a precipitation of the super-incumbent rocks into the watery gulf. The progress of this operation is obvious-the immense bodies of ice which are carried down from Lake Erie, must also be a powerful auxilia$r y$, and frest and earthquakes unquestionably contribute greatly to the production of these results.

If below the outlet of Lake Erie, any chasm should be produced by earthquakes or any other cause which would remove the lime stone rocks, and enable the water to reach the soft sand stone and red clay, the fissure would enlarge, and in course of time the whole intervening rocks would be swept away, and Lake Erie would plunge into Lake Ontario. The great plateau, or table land, below Lewiston, would then be deluged, and the age of Deucalion would visit this portion of the great western region.

$\Lambda t$ the feet of great falls of water and in the bosom of sequestered ravines, the devotee of natural science generally funds a fertile field of investigation. This cataract however does not furnish many interesting specimens of mineralogy, but its neigliborhood is rich in botany. The banks of the river about the falls are lined with white pine and cedar. One of the latter was pointed out to me which leans terrifically twenty feet over 
the great eastern bank, and in the crotch of which a most beautiful and accomplished lady from Boston, took a picturesque vitw of the falls.

Charlevoix tells of ten or twelve Ottaways who, in trying to cross over to Goat Island in order to aroid the pursuit of the Iroquois, were drawn over the falls in spite of all their efiorts.

In the autumn of 1810 , a salt boat with four men, bound up to Black Rock with 150 barrels of salt, was upset, and drifting down the river, went over the falls. All perished but one person, who escaped at first by the rudder, and finally swas taken up by a boat from Chippewa. Next spring a canoe with three men was carried down the cataract.

Near the British shore, and between the Bridgewater mills and the cataract, there is a small grass island about mid way between the shore and Goat Island. A deer took the water near Chippewa at a point above this island, and fell down upon. it, where he could not be approached-and after remaining there nearly a day and night, was not to be seen the ensuing morning. An anecdote is told of an old blind mare, which shows superior sagucity. She went into the water above the rapicis of Niagara to cool herself. She was unable to find her way out, and she had descended. into the vicinity of a place where she would have 
been inevitably carried down. Some boys, anxlous to see her swept down the cataract, and impatient at the delay, threw stones at her. This indicated the way of escape, and she immediately returned in that direction.

The passage of the river below the cataract is not considered dangerous. There is a boat stationed there for the conveyance of passengers, in which I have passed. During the late war smuggling was carried on in that direction in the night time, and before a ladder was erected on the east bank, peoplefrequently passed over from Canada to steal apples at Fort Schlosser.

But I see, my friend, that you are not only tired of the subject, but of the manner in which I have handled it. A description of this mighty cataract is the Ulyssean bow of travellers. I could say much more, but I shall only trespass surther on your patience by stating that 1 have been credibly informed, that Dr. Kerr, an intelligent and respectable inhabitant of Bridgewater, who has resided in Upper Canada thirty years, marked a tree at that time on each shore of the cataract, and now believes that there has been a retrocession of 150 feet in his time, chiefly at the centre of the crescent. You can see immense piles of stones thrown down at the foot of the 
cataract, and masses on the bank of the precipice, protruding from the summit of the cataract over the yawing guld.

\section{LETTER XLVIII.}

\section{Western Region, September, 1820.}

Mir Dear Sir,

IT tras been found that the loss of water in the canal exceeds the original estimate. Whether this is most owing to soakage, leakage, or to the power of evaporation, may be a subject of controversy. I am inclined to believe that in all thesc respects the diminution has been greater than was anticipated. While the former will cease to operate, in proportion as the canal is rendered more impermeable and tight, the latter must continue with the duration of the world.

Many calculations and experiments have been made, at various times, to determine the quantity of rain and quantity of evaporation in different parts of the world. Dr. Halley estimated that 6914 tons of water are evaporated from every square mile of the sea in a day; and Dr. Shaw has applied this estimate to the Dead Sea, and considering the river Jordan about thirty yards wide, and taking three feet for the mean depth of 
the stream, and allowing it to run two miles an hour, it discharges every day into the Dead Sea, $6,090,000$ tons of water ; whereas this sea being 72 miles long and 18 broad, there will be drawn up by evaporation $S, 960,000$ tons, and this difference between the supply and the diminution must be made good from some other source. Dr. Halley, upon a supposition that the Mediterranean Sea covers 160 square degrees, infers that î̀ must lose in vapour in a summer's day at least 5280 millions of tons, and that all the rivers which run into it only furnish 1827 millions of tons in the same period. Bishop Watson calculates, that 1600 gallons of water evaporate from an acre of ground, in twel e hours' sun. Dr. Williams of Vermont, says that an acre of ground, covered with trees, throws out in twelve hours, 3875 ga!lons of water; and he further states that the evaporation from a surface of land, covered with trees and other vegetables, is one third greater than from a surface of water. And he also asserts that in Bradford, New England, the evaporation amounted in 1772 to 42.65 inches. Dr. Dobson states the yearly evaporation in Liverponl to be 36.78 inches. But the most accurate experiments on this subject were made by Dalton, at Nanchester, for three years in succession : and the mean rain for that period was 53.55 inclies annually; 
the mean evaporation from the green ground 25.14, and from water 44.43. From this it appears that the evaporation from a surface of water is nearly twice as much as from green ground; and also, that about eight or nine inches of rain are left for the supply of springs and rivers. This surplus of water must be drawn from the sea, and must return to it again by rivers. It must be obvious that these experiments and estimates are by no means unerring. But it is supposed that the mean annual evaporation over the whole surface of the earth, is 35 inches for every square inch, and that therefore 94,450 cubic miles of water are annually evaporated over the whole globe.

Considering the climate of the country through which the canal runs - the great heat of the summer-the protracted autumn-and the comparitively mild winter, it is not unreasonable to increase the general calculation in its application to that region five inches on green earth, and ten inches on water. The whole annual evaporation of the middle section of the western canal, reckoning that each square inch evaporates in that time 45 , will only amount to $9,212,444$ hogsheadsa loss certainly of no great consequence when we consider the supply. 
The mean quantity of rain falling at the following places, in one year with another, is,

In Europe-at Hærlaem 24 inches

Delf 27

Dort 40

Middleberg 33

Paris 20

Lyons 37

Fome 20

Padua 3\%

Pisa $34 \frac{1}{2}$

Ulm 27

Berlin 197

Lancashire 40

Essex $19 \frac{1}{2}$

Manchester 33.55 before men-

[tioned.

And in the United States:

In Charlotte, South Carolina, 47.66 inches. In Williamsburgh, Virginia, 47.038

In Cambridge, Nassachusetts, 35.396

In Rutland, Vermont, $\quad 41.197$

Making every allowance for defective or erroneous experiments, it is clear that there is more rain as well as more evaporation in this country than in Great Britain. That there is more evaporation, must be evident from the superior heat. 
of this climate, and from the insular situation of the latter country.

In applying these facts to the canal, I do not see that there is any reason to apprehend a scarcity of water, either from the quantity of evaporation or the failure of rain. Whatever is taken up by the one, will be returned with increase by the other. And the vicinity of the great lakes will furnish a never failing and plentiful reservoir for all the purposes of evaporation, which will either be returned to the earth in dew or in rain. But difficulties may occur, when the drain and the supply are not contemporaneous. The greatest evaporation takes place during the prevalence of the greatest heat, and the greatest floods of rain occur in spring and autumn. But considering the numerous streams and lakes which can we pressed into the service of the canal, there is Ho donger but that their wonted supply will more than transcend the deficiencies of temporary droughts and dearths. It is however well known that cultivation has a great influence on the waters of a country-by precluding evaporation from trees, and by creating eight times more evaporation than existed before opening way for the action of the sum. Besides, the loosening of the earth has a tendency to choke up and absorb fle streams. 
"I'he streams are supplied from swamps-from springs-aud from an union of both. Cultivation dries up the streams which proceed from swamps, and diminishes pro tanto those that are fed partially from that source. Even those derived from springs exclusively, may be deprived of their supply by various causes. Springs fail as well as marshes, but not so often, and this may be owing to the failure of rain, ol to the clay which holds the water, giving way for a less tenacious substance. On the other hand, the clearing of a country sometimes exhibits waters formerly concealed in the cavities of rocks, by filling up the fissures with earth; and in former times the leaves of trees thickening on the surface of the earth formed a compact bed, which exposed the rain water collected in it to the power of evaporation, but the removal of the leaves and the opening of the earth by cultivation, enable the rain to penetrate into the ground, and to collect in copious and perennial springs bolow the iuflucnce of solar heat. 


\section{I.ETTER XLIX.}

Western Region, Septembat, 1820.

Mr Dear Sir,

Is one of my solitary walks with my gun on sny shoulder, and my dog by my side, I strayed eight or ten miles from my lodgings; and as I was musing on the beauties of the country, and meditating on the various and picturesque scenes which were constantly unfolding, I was roused from my reverie by voices which proceeded from persons at a short distance. In casting my eyes in that direction, I saw two venerable men with fishing rods in their hands angling for trout, in a copious and pellucid stream which rolled at their feet. I was hailed by them, and requested to approach, which I immediately did, and in exchanging salutations, I found that they were men of the world, perfectly acquainted with the courtesies of life. One of them held up a string of fine trout, and asked me in the most obliging manner to go home with them and partake of the fruits of their amusement. Struck with the appearance of the strangers, and anxious to avail myself of the pleasure of their company, I did not hesitate to arcept of this hospitable offer, on condition that the would permit me to add the woodcock, snipe, 
and wood ducks, which were suspended from my grun, to their acquisitions. This offer was kindly accepted. A general and desultory conversation ensied, and we arrived in a short time at a small village, and on ascending the steps of an elegant house, I was congratulated by my new friends on my entry into Oldenbarneveld. In the course of an hour, dinner was served up, I sat down and enjoyed a treat worthy to be compared to the Symposior of Plato. I soon found that these venerable friends were emigrants from Hollandthat they were men of highly cultivated minds, and polished manners-and that they had selected their habitations in this place, where they en joyed

"An elegant sufüciency, content,

Retirement, rural quiet, friendship, books,

Ease and alternate labor, useful life,

Progressive virtue and approving Heaven,"

The elder of these gentlemen had received the hest education which Holland could afford. He was brought up a clergyman, and at the com. mencement of the American revolution, he became its enthusiastic and energetic advocate, and wrote an able work in vindication of its character and conduct. In the struggles which subsequently took place in his native country, he sided with the patriots. His friend held a high military 
office curing that commotion, and unites the frankness of a soldier and the refinement of a gentleman with the erudition of a scholar.

During their residence in this country, they have been attentive to its interests. As far back as 1795, the elder gentleman proposed an Agricultural Society for this district, and addressed it in a luminous speech.

I was penetrated with the most profound respect, when I witnessed the various and extensive acquirements of this man. He is a perfect master of all the Greek and Poman authors-skilled in Hebrew, the Syriac, and the other oriental languages-with the German and French he is perfectly acquainted-His mind is a great and inexhaustible store-house of knowledge; and I could perceive no deficiency, except in his not being perfectly acquainted with the modern discoveries in natural science, which arises in a great degree from his sequestered life. He manages an extensive correspondence with many learned men in Europe, as well as America. And although I had never heard of him before, yet I am happy to understand that his merits are justly appreciated by some of the first men in this country.

He has lately been complimented with a degree of Doctor of Laws, by a celebrated university of New-England. He is now employed by the state 
of New-York in translating its Dutch Recordsand through the munificence of David Parish, the great banker, he will be enabled to have transcripts of the records of the Dutch West India Company to fill up an important chasm in the history of this great state.

Thus, my friend, I have made a great discovery. In a secluded, unassuming village, I have discovered the most learned man in America, cultivating, like our first parent, his beautiful and spacious garden with his own hands-cultivating literature and science-cultivating the virtues which adoru the fire side and the altar-cultivating the esteem of the wise and the good-and blessing with the radiations of his illumined and highly gifted mind, all who enjoy his conversa tion, and who are honored by his correspondence,

\section{LETTER L.}

Utica, September, 1820.

MY Dealr SrR,

Is the course of my tours, I frequently meet with extraordinary characters-indeed, I think that there are more persons of this description in this, than in any other country. Eccentricities and peculiarities of conduct will always prevail 
most in democratic countries, where freedom is indulged in all the modifications of thought, speech, and action, that do not infringe on the laws; and as the population of America is derived from almost all the nations of Europe, it must unquestionably combine heterogenous qualities, which have not as yet been moulded into uniformity and sameness. What Rochester in his witty poem upon nothing said ironically, may, as it respects part of the tirst, and the whole of the second line, be applied in sober seriousness to the Anerican people:

"French trith, Dutch prowess, British policy,

Mibernian learning, Scotch civility,

Spaniard's despatch, Dane s wit, are mainly seen in thee.'

In my last voyage on the canal, I met with an old sea Captain, who appeared to unite in his character the lionest bluutness and generous frankness of a sailor, with the characteristic ingenuity and enterprising spirit of the Yankee. He had before the revolution commanded sea vessels from eastern ports. He had often doubled Cape Horn, and pursued the whale in the great South Sea. He had visited many of the ports of Great Britain, and every island in the West Indies was familiar to him. At the breaking out of the Revolutionary war, he entered on board a priva - 
teer as second in command-was captured by a 50 gun ship-and incarcerated in the prison-ship in New-York, where he lingered out years of squalid wretchedness. On the return of peace, he resumed his profession; but being thrown out of business by the system of commercial restrictions, he turned his eyes to the regions of the west, and procuring a batteau, he embarked with his wife, family, and furniture, from a small port in Connecticut. Like our first parents-

"The world was all before them, where to choose

Their place of rest, and Providence their guide."

He sailed up the Hudson river to Albany, and after conveying his boat and accompaniments by land to Schenectady, he navigated the Mohawk to Rome. After many unsuccessful attempts to select a residence, he finally fixed his habitation near the Oneida Creek. On the day of his arrival, he erected a shed with a bark covering, open at the sides. In the centre he kindled a fire, and committing themselves to the guardian care of Providence, the family, after a homely repast, spread themselves for sleep on the ground, serenaded by the growling of bears, the howling of wolves, and the barking of foxes. The next day, the bark shed was converted into a building called a chanty, and the dwelling has since become a single story frame liouse of humble dimensions. 
It is useless to describe the early sufferings of this family in a new country, in a new theatre of action-without neighbors to assist-without physicians to heal-without ministers of the gospel to console. The cultivation of a garden, a cornfield, a potatoe patch, and the rearing of poultry, hogs, and cows, employed all their attention. In a few years, settlements were formed round them, and as the blessings of comfort, society, and plenty, were brightening about them, the wife of the old seaman died. His children were married, and had removed to a distance-and his only consolation was an orphan grand-daughter, which his deceased wife had brought up. She acted as his nurse-his house-keeper-and superintended all his domestic economy.

When death separates in old age those who have been united in marriage, and who have lived in the reciprocations of affection, the survivor rarely lives any leugth of time. Hæret lateri lethalis arundo. The gangrene of the heart is incurable. A morbid melancholy, which continually increases by nursing its sorrows, and brooding over its aflictions, gradually, if not quickly, undermines the vital principle.

The old sailor was in this situation for a year, going to his final resting place, with slow, but unceasing steps; and all the consolations of friend- 
ship, and employments of labor were incompetent to rouse him from his sorrows, and to stimulate him into enjoyment. He kept his eye steadily fixed on futurity, and he looked forward with exultation to the period when he should be united with his departed friends in another and a better world.

He continued in this state of mind until the canal was completed from Utica to Montezuma. It passed close by his door. In the early stages of its progress, he considered it with apathy, if not with contempt-but the first boat which passed by his house awakened his slumbering energies. There was indeed something grand, sublime and animating in the scene-the shouts of spectatorsthe huzzas from the boat-

"The neighing steed, and the shrill trump, The spirit stirring drum, the ear-piercing fife, The Eagle banner-and all quality, Pride, pomp, and circumstance of glorious exultation."

He entered the vessel and was delighted. He called to his mind the adventures of his youth-the pursuits of his manhood-and the bustling scenes of his active life. He returned, and slept well. He rose in the morning as lively and as joyous as the lark. He thought he could also construct a boat, and on a better plan - he set to work, and succeeded. He is now in full requisition for that 
purpose. He is surrounded by plenty, and his time is constantly engaged in his new vocation. Thus by a singular metamorphosis the ship master of the ocean, has become a boat builder on the western canal; and whenever the demon of melancholy, like the evil spirit of Saul, attempts to take possession of him, a trip on the great artificial water operates like the harp of th. swset singer of Israel.

I am, \&c.

\section{HIBERNICUS.}








\section{THE NEW YORK PUBLIC LIBRARY REFERENCE DEPARTMENT}

This book is under no circumstances to be taken from the Building

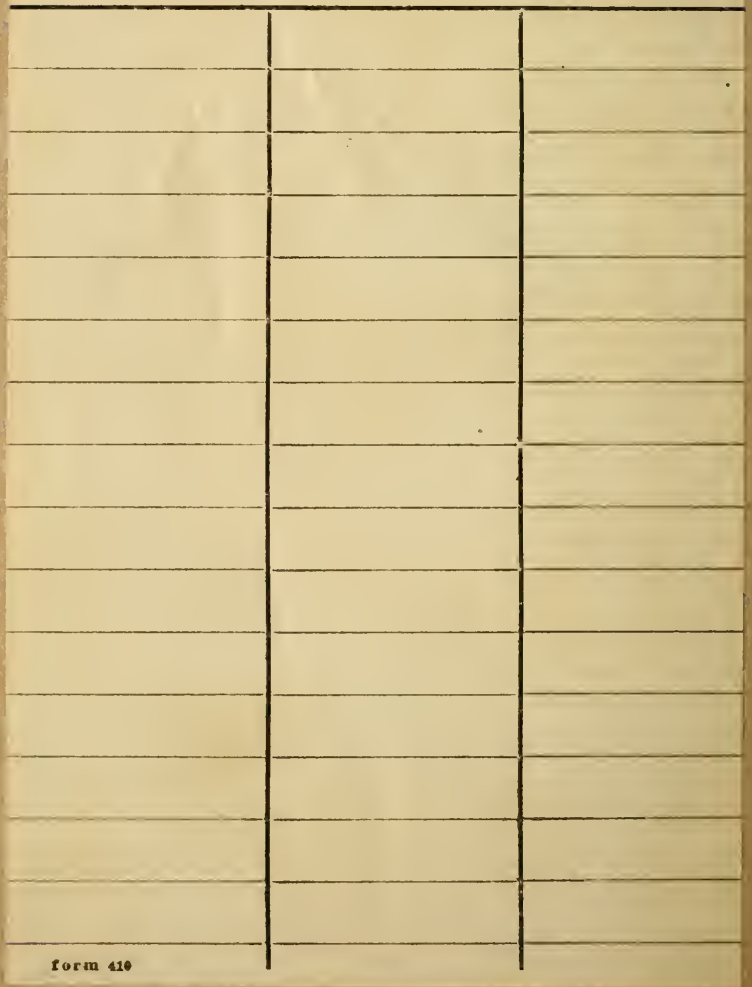



